\title{
DOES INFRASTRUCTURE REFORM WORK FOR THE POOR? A CASE STUDY FROM GUATEMALA ${ }^{1}$
}

\author{
VIVIEN FOSTER ${ }^{2}$ AND MARIA CARIDAD ARAUJO
}

World Bank Policy Research Working Paper 3185, January 2004

The Policy Research Working Paper Series disseminates the findings of work in progress to encourage the exchange of ideas about development issues. An objective of the series is to get the findings out quickly, even if the presentations are less than fully polished. The papers carry the names of the authors and should be cited accordingly. The findings, interpretations, and conclusions expressed in this paper are entirely those of the authors. They do not necessarily represent the view of the World Bank, its Executive Directors, or the countries they represent. Policy Research Working Papers are available online at http://econ.worldbank.org.

\footnotetext{
${ }^{1}$ This research was originally prepared as a Background Paper for the Guatemala Poverty Assessment 2002.

${ }^{2}$ Vivien Foster is an Economist with the Finance, Private Sector, and Infrastructure Unit of the Latin America and Caribbean Region of the World Bank (vfoster@worldbank.org).

${ }^{3}$ María Caridad Araujo was a Doctoral student in the Department of Agricultural and Resource Economics at the University of California at Berkeley at the time when the research was conducted (caraujo@are.berkeley.edu).
} 


\section{Acknowledgements}

The authors are particularly grateful to Kathy Lindert (Task Manager of the Guatemala Poverty Assessment) for excellent guidance and undying support, and to fellow team members Michele Gragnoloti and Alessandra Marini for close collaboration on the health section of this paper.

Extremely helpful comments on an earlier draft were received by the following participants at a World Bank internal seminar: Kulsum Ahmed, Ana María Ibañez, Masami Kojima, Alessandra Marini, Maurizia Tovo, Jean-Philippe Tré, and Renos Vakis.

The following people played the invaluable role of providing the background information needed for the study: Tofic Abularach (Unidad Nacional para Acueductos Rurales); Carlos Becerra (INE); Franz Drees (World Bank); José Luis Guasch (World Bank); Ada Karina Izaguirre (World Bank); Chris Jennings (Inter-American Development Bank); Francisco Marroquín (Fondo Nacional para la Paz); Jose Romeo Orellana (Superintendencia de Telecomunicaciones); Kilian Reiche (World Bank); Amalia Sandoval (GUATEL); Marina Segastume (Fondo de Inversión Social); Maurizia Tovo (World Bank); Ricardo Velado (Instituto Nacional de Electricidad); Sergio Velásquez (Comisión Nacional de Energía Eléctrica); Harris Whitbeck (Fondo de Solidaridad y Desarrollo Comunitario); Eduardo Zolezzi (World Bank). 


\section{Executive Summary}

Following the 1996 Peace Accords, Guatemala embarked on a major program of infrastructure reform involving the restructuring and privatization of the electricity and telecommunication sectors. At the same time, the volume of social fund resources channeled towards rural infrastructure programs increased from US\$17 million in 1993/6 to US\$152 million in 1997/01. Moreover, a further US\$120 million of privatization proceeds were earmarked for rural electrification and telephony.

As a result, the pace of new connections to water, electricity and sanitation services increased significantly from 80,000 new connections per year for each service in the period 1993/6 to 115,000 new connections per year in the period 1997/01. Moreover, households in traditionally excluded sectors - the poor, rural, and indigenous populations - were twice as likely to be the beneficiaries of a new infrastructure connection than they had been prior to the Peace Accords. Connections to modern utilities are shown to bring significant time savings to rural households, and have a substantial impact on the profitability of home-based microenterprises.

The most dramatic change came in the telecommunications sector where the teledensity index increased by a factor of five from 4.2 in 1997 to 19.7 in 2001 . Much of this growth has come from cellular telephony which now accounts for $57 \%$ of all telephone subscriptions in Guatemala. Although about half of these cellular telephones represent second lines for the highest income groups, the remainder provide substitutes for fixed line telephones particularly in rural areas where they are often operated as informal public telephones. Furthermore, the number of official public telephones in rural areas has increased by $80 \%$ since the Peace Accords, so that $80 \%$ of rural households now live within six kilometers of a public telephone.

Notwithstanding the significant progress made, the achievement of universal access to modern utility services is likely to take Guatemala a further 10 years and cost the country an estimated total of US\$1 billion. However, it is important to note that about a third of those households that do not have piped water and electricity, live next door to households that do have these services. This suggests that the achievement of universal access will need to address demand-side barriers in addition to financing the expansion of infrastructure networks.

Although real electricity tariffs increased by between $60 \%$ to $80 \%$ following the reform, residential consumers have been shielded as a result of a 'social tariff' policy that has kept charges at pre-reform levels of US $\$ 0.08$ per kilowatt-hour for up to 300 kilowatt-hours per month. In practice, this policy-which costs US\$50 million per year-does little to benefit poor households. The reason is that $60 \%$ of them are not connected to the electricity network at all, and those that are consume only small amounts of electricity and hence capture only $10 \%$ of the total value of the subsidy. By contrast, poor households without access to electricity pay the equivalent of about US\$11 per kilowatt-hour (or 80 times the electricity tariff) to light their homes with candles and wick lamps. Seen from this perspective, the US $\$ 50$ million per year used to finance the 'social tariff' would be better employed in financing new connections for these households.

In the water sector, where there have been no reforms, tariffs are kept well below costs at US\$0.10 per cubic meter. As a result, most households pay monthly bills of between US\$1 to US $\$ 2$, which absorbs barely $0.5 \%$ of the household budget and is well below the 3\%-5\% affordability guideline used by the World Health Organization. Even then, only $70 \%$ of households report paying their water bills. Moreover consumers have little

confidence in water quality, with three quarters of them either buying bottled water or undertaking some form of self-treatment. Indeed, the practice of boiling drinking water is equally prevalent among those that have and do not have piped water. 


\section{Table of Contents}



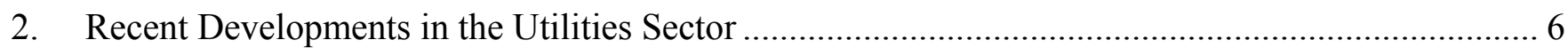

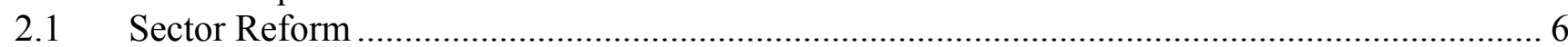

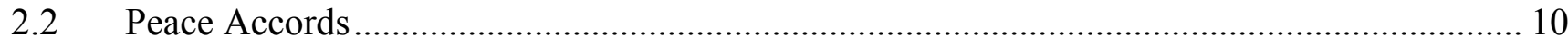

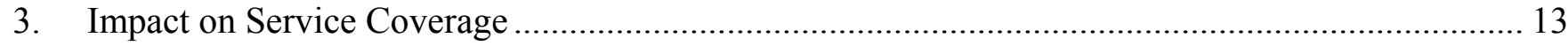

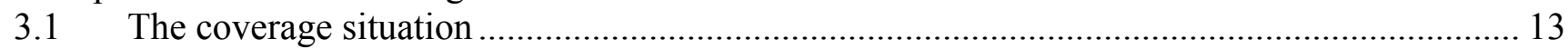

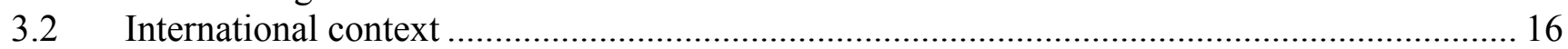

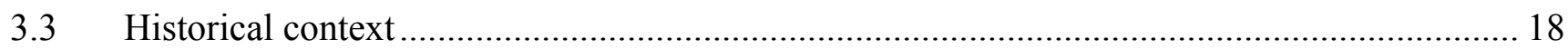

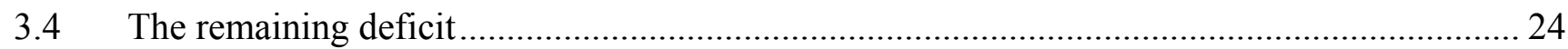

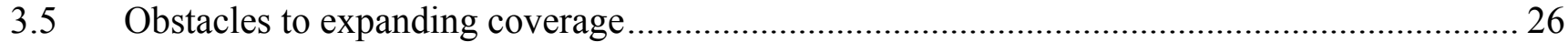

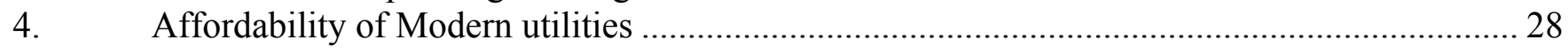

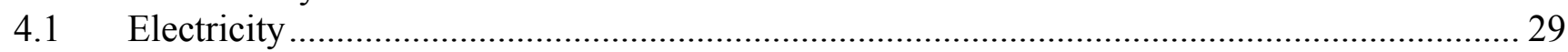

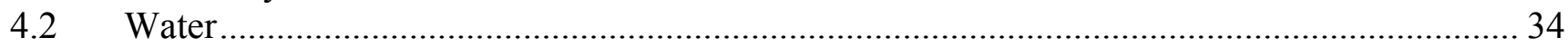

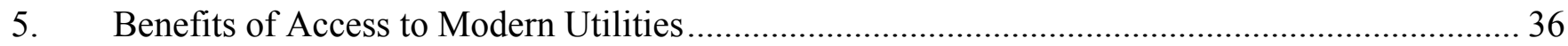

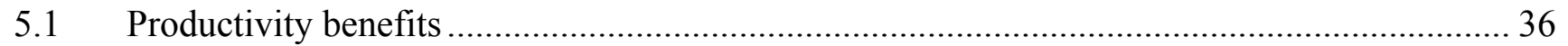

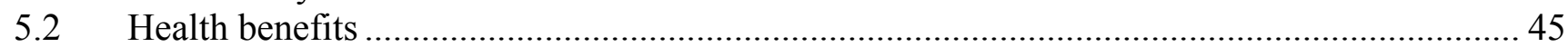

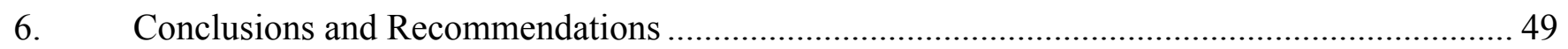

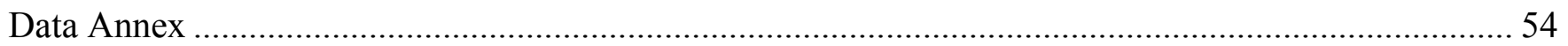

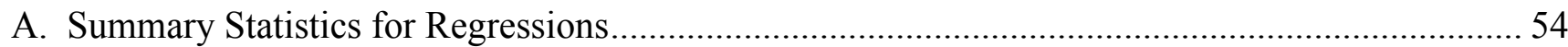

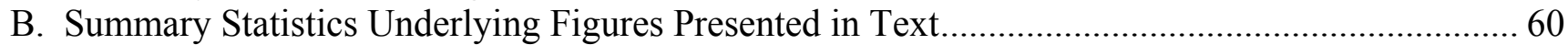

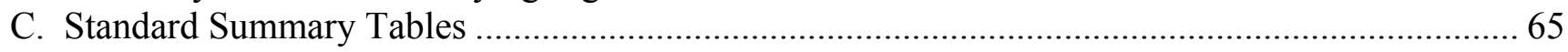

D. Explanations of Coverage, Take-Up and Availability....................................................... 78 


\section{Introduction}

'Para [el desarrollo] es imprescindible la infraestructura básica, de comunicación, electrificación y la productiva. La inversión pública se deberá orientar prioritariamente con ese propósito y se establecerá un marco de incentivos a la inversión para el desarrollo rural en las áreas consideradas.' Acuerdos de Paz, 1996.

The 1996 Peace Accords acknowledged the pivotal importance of modern utility services ${ }^{4}$ in the Guatemalan development process, and made a commitment to expanding coverage to disadvantaged groups in order to make-up for historic neglect. This commitment has given rise to substantial changes in the utilities sectors in Guatemala. On the one hand, the electricity and telecommunications sectors have undergone profound structural transformation, through an ambitious program of privatization and market liberalization. At the same time, the volume of resources channeled towards rural service expansion has been tripled through a variety of new and existing institutional mechanisms.

Poor households typically have much lower rates of access to modern utility services than the rest of society. As a result, they often rely primarily on traditional substitutes, consuming water from local rivers, meeting their sanitation needs in the open air, lighting their homes with candles, cooking with fuel wood collected from local forests, and traveling personally over long distances to pass on messages to distant relatives or business associates.

There a number of barriers that explain why many low income households remain uncovered by modern utility networks. They include inadequate development of physical infrastructure, prohibitively high capital costs of access, or in some cases lack of cultural familiarity or information about the services in question and their advantages.

As a result of this exclusion, poor households suffer a number of handicaps. First, the unit cost of some traditional substitutes is often considerably higher than the corresponding modern alternatives. For example, lighting with candles is very much more expensive per kilowatt-hour than lighting with electricity. Similarly traveling to a distant town to relay a message is often much more expensive than making a telephone call. Again, time spent collecting and storing water may be costly in relation to the price of a piped service. Where costs are high, households may consume too little of the service to satisfy subsistence requirements. For example, households may not be able to afford enough water to meet basic hygiene needs.

Second, access to modern services can substantially enhance the productivity of households and household-based micro-enterprises. Many of the traditional substitutes for modern services are time intensive to use (for example, collecting water and fuel-wood, or relaying messages). Time liberated from these tasks can potentially be reallocated to income generating activities, or in the case of children to education. Furthermore, electricity makes possible the use of appliances that substantially increase productivity and hence income generating potential of micro-enterprises (pumps, sewing machines, power tools), while information and communication technologies enhance the availability of market information and the possibility of social and political participation.

\footnotetext{
${ }^{4}$ For the purposes of this discussion, modern utility services are defined to include water, sanitation, energy, and telecommunications. Water is defined as having piped water in the dwelling or yard. Sanitation is defined to include latrines, septic tanks and sewerage.
} 
Third, some traditional substitutes for modern utility service are associated with adverse health impacts and may contribute to infant mortality. Inadequate water and sanitation may give rise to waterborne diseases, while cooking with biomass fuels has often been linked to respiratory ailments. In this sense, infrastructure could be regarded as an input into the health production function that complements hygiene practices and health care interventions.

This paper explores how the important policy changes experienced in the utilities sector in Guatemala since the Peace Accords have affected the lives of poor households. First, Section 2 examines to what extent service expansion programs have succeeded in reversing the inequities that have traditionally existed in access to modern utility services, and the barriers that remain in achieving universal coverage. Second, Section 3 looks at how tariff reforms and related subsidy policies have affected the affordability of modern utility services for the poor. Finally, Section 4 attempts to quantify the broader benefits that such services bring to poor households, in terms of improved health and productivity. A Data Annex provides a set of standard cross-tabulations of all of the basic variables of interest by geographical, ethnic and economic categories. It also gives the descriptive statistics for each of the regressions reported in the paper, as well as tabulations of the numbers underlying each of the graphics.

The analysis draws primarily on household level data collected during the ENCOVI 2000 Survey; the first survey ever to be conducted in Guatemala in accordance with the Living Standards Measurement Survey methodology. The ENCOVI covered 7,276 households, drawn from 745 census clusters of UPM (Unidad Primaria de Muestreo), and is designed to be statistically representative at the national level, and of a number of strata including urban and rural areas, the country's eight geographical regions, and the main ethnic groups established in the 1994 census ${ }^{5}$. In some areas, it is possible to match-up the results of the quantitative analysis against subjective perceptions of poverty recorded in a parallel Qualitative Poverty and Exclusion Study (QPES), which conducted in-depth focus group interviews in nine communities selected to represent a broad ethnic cross-section of Guatemalan society. The survey data is complemented by sectoral statistics collected directly from the key policy-making and regulatory bodies, as well as a number of donor agencies active in the country ${ }^{6}$.

\section{Recent Developments in the Utilities Sector}

This section provides a brief overview of the policy context each in the three utilities sectors: telecommunications, energy, and water and sanitation services. Two important developments are documented. First, the sector reform movement that has led to a complete transformation of the telecommunications and electricity sectors, but has yet to make any impact on the water and sanitation sector. Second, the various policies that were established to promote expansion of service coverage in rural areas.

\subsection{Sector Reform}

\section{Electricity}

Prior to reform, electricity was provided by two state-owned companies: EEGSA, which was responsible for electricity distribution in the metropolitan region; and INDE, which controlled the

\footnotetext{
${ }^{5}$ Kiche, K'aqchikel, Mam, Q'eqchi, 'other Maya' and 'other indigenous'.

${ }^{6}$ Throughout the study, quintiles are based on per capita household consumption..
} 
remaining generation, transmission and distribution assets nationwide. The Electricity Law of 1996 (Decreto 93-96) sought to increase investment and improve efficiency in the sector by introducing competition in electricity generation, and privatizing the distribution networks. A regulatory agency, the Comisión Nacional de Energía Eléctrica (CNEE), was created to oversee the new system.

Table 2.1: Summary of structural changes in Guatemala telecommunications sector

\begin{tabular}{l|l|l}
\hline & Pre Reform & Post Reform \\
\hline Generation & INDE monopoly & $50 \%$ INDE (hydroelectric) and 50\% Independent Power Producers (thermal) \\
Transmission & INDE monopoly & INDE monopoly \\
Distribution & EEGSA, DEORSA, DEOCSA & Privatized EEGSA, DEORSA, DEOCSA \\
\hline
\end{tabular}

In 1998, an 80\% stake in EEGSA was sold to Iberdrola of Spain. While the distribution assets of INDE were broken down into two regional distribution companies, DEORSA and DEOCSA (serving the east and west of the country respectively), which were also privatized in 1998. One investor purchased both companies: Unión Fenosa of Spain.

Notwithstanding the reforms, the state-owned enterprise INDE retains a dominant position in the system. It controls about half of the country's (mainly hydroelectric) generating plants, but competes with independent power producers that control the rest of the (primarily thermal) capacity. Furthermore, INDE continues to own and operate the national transmission grid.

An important benefit of the electricity sector reform has been the rapid increase in coverage, from 53\% in 1996 to $70 \%$ in $1999^{7}$. However, prices have also risen substantially. Under the new regulatory framework, the privatized distribution companies are allowed to pass on to the customers the variations in the purchase cost of energy. Due to the fact that the current Power Purchase Agreements signed between generators and distributors are indexed to the US dollar and the price of oil, prices have risen substantially since 1998 , between $60 \%-80 \%$ depending on the company.

Another issue that remains problematic in the electricity sector is that of illegal connections. As reported in the ENCOVI survey, while $73 \%$ of the households report to be connected to the electricity network (95\% in the urban and 56\% in the rural areas), only $62 \%$ have an electricity meter (78\% in the urban and $50 \%$ in the rural areas). The lack of a meter suggests that these households are illegally connected, or at best, that the amounts they pay for the service are not proportional to their monthly consumption.

\section{Telecommunications ${ }^{8}$}

Until 1996, telecommunications services in Guatemala were the monopoly of GUATEL; a state-owned enterprise created in 1971. By the mid-1990s, there was growing dissatisfaction with the performance of GUATEL. Not only was the company comparatively inefficient (around 60 mainlines per 1,000 employees), but it was failing to satisfy mounting demand for telecommunications services. In 1996, Guatemala had one of the lowest teledensity ratios in Latin America with only 4.2 (fixed plus cellular) lines per 100 inhabitants. With only 350,000 fixed telephone lines in the country, unsatisfied demand was estimated at 1,000,000 lines.

\footnotetext{
${ }^{7}$ Official national coverage statistics provided by the regulatory agency, Comisión Nacional de Energía Eléctrica (CNEE). They are consistent with the coverage trends inferred from ENCOVI 2000 (see Section 3 below).

${ }^{8}$ The factual information reported in this section is either drawn from a number of World Bank Aide Memoires for the Guatemala Private Participation in Infrastructure Technical Assistance Project (Loan 4149-GU) or supplied directly by the Superintendencia de Telecomunicaciones.
} 
The Telecommunications Law of 1996 (Decreto 94-96) paved the way for one of the most radical market liberalizations witnessed in the region (Table 2.1). All barriers to competition were removed with immediate effect, as were all regulatory restrictions on prices and quality of service. This stands in contrast to most other reforming countries in Latin America, which have tended to pass through a transitional exclusivity period-during which the historical incumbent retains much of its monopoly power-and which have tended to retain regulatory safeguards on price and quality of service even after the introduction of competition.

Table 2.2: Summary of structural changes in Guatemala telecommunications sector

\begin{tabular}{c|l|l}
\hline & Pre Reform & Post Reform \\
\hline $\begin{array}{l}\text { Fixed telephony } \\
\bullet \quad \text { Local calls }\end{array}$ & GUATEL monopoly & $\begin{array}{l}\text { Privatized TELGUA plus 15 new entrants. } \\
\text { Privatized TELGUA plus 13 new entrants. }\end{array}$ \\
Cellular telephony & GUATEL monopoly & Three new entrants \\
\hline
\end{tabular}

The 1996 law also created a new regulatory agency, the Superintendencia de Telecomunicaciones (SIT). However, given the extent of deregulation in the sector, the functions of the SIT are limited to licensing and monitoring the use of the radio spectrum and resolving disputes involving telecommunications operators.

Although the privatization of GUATEL was an integral part of the reform strategy, this was delayed until 1998 owing to a variety of political and legal obstacles. In the end, due to legal obstacles, it proved necessary to transfer most of the assets of GUATEL (except for the network of rural public telephones) to a new company, TELGUA. The government then sold off a 95\% stake in TELGUA via auction to the private sector; the successful (and in fact only interested) bidder being TELMEX.

An important consequence of liberalization has been the need to rebalance call charges, to remove the cross-subsidy that previously existed from long distance to local calls. As a result, local call charges increased tenfold from $\$ 0.51$ per month (for the basic subscription including 200 free minutes; equivalent to $\$ 0.003$ per minute), to $\$ 5.64$ per month (equivalent to $\$ 0.028$ per minute). However, even this falls below the estimated economic cost of around $\$ 0.030$ to $\$ 0.033$ per minute.

There are now more than 250 companies involved in providing the full range of telecommunications services in Guatemala. These include a number of major international investors such as Bell South, Telefónica, TELMEX, and Millicom International. Although the local telephony market continues to be dominated by TELGUA, with $95 \%$ of all fixed line subscribers, sixteen other companies have entered the market competing primarily in the most lucrative market niches, such as Guatemala City.

Competition for long distance services has been more vigorous, with fourteen players in all, and four major players. The combination of tariff-rebalancing and competition has led to dramatic reductions in long distance charges, from US\$1.50 per minute to the United States in 1996 , to around US\$0.30 per 
minute in 1998. More recently, charges have fallen to around US\$0.15 per minute as a result of the introduction of the possibility of teleselection of the long distance operator ${ }^{9}$.

In addition, four licenses have been issued for mobile telephony services. Calls are charged at around $\$ 0.14$ per minute, with some calling plans costing less than $\$ 10$ per month.

The reform has had a major impact on the performance of the telecommunications sector in Guatemala. The efficiency of the sector improved markedly, with the number of mainlines per 1,000 employees rising from 60 in 1996 to 130 in 1999 . While, at the same time there have been massive gains in coverage.

According to SIT data, the total number of fixed plus cellular telephone lines rose almost fivefold from around 350,000 to over 1,600,000 between 1996-01, raising the teledensity index from 4.2 to 19.7. Much of this growth came from new cellular lines, which now represent more than half of the total (57\%). The development of the cellular network has been less concentrated in the capital city. Whereas in $2001,70 \%$ of the country's fixed lines were located in the Department of Guatemala, only $43 \%$ of the cells of the mobile telephony network were located in that Department.

\section{Water and sanitation}

Although sector reforms have been under discussion for some years in the water sector, it has not been possible to reach a political consensus on this issue.

At present, the provision of water and sanitation services in the metropolitan region remains the responsibility of the state-owned enterprise EMPAGUA. EMPAGUA serves about $70 \%$ of the market in the central city area (falling to 50\% if the surrounding municipalities are taken into account). More than 200 private companies meet the shortfall in demand, of which the largest are Aguas de Mariscal and San Cristóbal, but the majority are small-scale operations serving a specific neighborhood or housing estate. A recent study (Solo, 1999) found that whereas charges by the main utility fell in the range \$0.09-\$0.42 per cubic meter depending on the consumption group, charges applied by alternative suppliers were substantially higher at between $\$ 0.25-\$ 2.70$ per cubic meter.

Table 2.3: Summary of the structure of the Guatemala water and sanitation sector

\begin{tabular}{l|l} 
Metropolitan area & $50 \%$ EMPAGUA, 50\% small scale private operators \\
Non-metropolitan urban areas & Municipal utilities \\
Rural areas & Community Based Organization with support from central government UNEPAR
\end{tabular}

Outside of the metropolitan region, the country's 240 municipalities are responsible for providing water and sanitation services, at least in urban areas. However, they do not tend to reach isolated rural areas, where community-based organizations typically take charge of services, often with some financial support from central government via the Unidad Ejecutora del Programa de Acueducto Rural (UNEPAR) or from the various social investment funds.

\footnotetext{
${ }^{9}$ The lower cost of international calls is an important consideration for the approximately $10 \%$ of households in Guatemala who obtain about $10 \%$ of their income from international remittances.
} 
A number of recent sector reviews ${ }^{10}$ comment on the precarious financial position of many of the service providers, due to the relatively low level of water tariffs and the political unwillingness to raise them closer to cost recovery levels.

According to the ENCOVI survey, $69 \%$ of households have piped water and $87 \%$ of the households have some form of sanitation; although only $38 \%$ are connected to the sewerage network.

\subsection{Peace Accords}

The 1996 Peace Accords acknowledged the pivotal importance of modern utilities in the development process, and the historical neglect of the infrastructure needs of rural and disadvantaged urban communities. Although no quantitative targets were set, the Peace Accords made concrete commitments to expanding coverage of electricity, water and sanitation, as well as public telephones.

Following the Peace Accords, two main mechanisms were used to channel greater volumes of finance into (particularly rural) infrastructure.

First, both in the electricity and telecommunications sectors, some of the proceeds of privatization were earmarked to finance rural expansion programs.

In the electricity sector ${ }^{11}$, the net sale revenues from the privatization of the two non-metropolitan distribution companies (DEORSA and DEOCSA), totaling US\$110 million, were placed in a trust fund to be used to finance a five-year rural electrification program (PER). The fact that the government was willing to sacrifice such a significant sum of potential fiscal revenue to support rural service expansion is unusual within the Latin American experience of privatization, and indicates the degree of commitment that exists to rural electrification. The objective of the PER is to connect 2,633 communities to the national grid during the period 2000-05, at a total cost of US\$333 million. The two distribution companies DEORSA and DEOCSA are contractually responsible for executing the investments. Since the program became active in 1999, almost US\$55 million have been disbursed. As a result, about $23 \%$ of the coverage target has been met, with a further $5 \%$ in the pipeline. The projects executed to date suggest that the average cost of electrifying a rural household is of the order of US $\$ 1,000$, which is not unusual by international standards.

In the telecommunications sector ${ }^{12}, 70 \%$ of the proceeds of the spectrum auctions held for mobile telephony services (up to an annual ceiling of US\$5 million) were allocated to a special fund (FONDETEL) designed to support the expansion of public telephones in rural areas. In line with best practice in a number of other Latin American countries (notably, Chile, Colombia and Peru), FONDETEL bid out the construction and operation of public telephones to the private operator requesting the minimum subsidy. Between 1998/99, FONDETEL disbursed US\$7.5 million of subsidies for the installation of some 1,600 public telephones. Each US\$1 of subsidy leveraged between US\$2-4 of private investment, so that the total subsidy cost per town was US $\$ 4,400$. However, unfortunately, the revenues from spectrum auctions have now been exhausted and no additional funding source has been identified for FONDETEL. While GUATEL - the state-owned company that continues to hold the rural

\footnotetext{
${ }^{10}$ See for example CEPIS, 2000 and IDB, 2001.

${ }^{11}$ Information provided directly by INDE.

${ }^{12}$ Information provided directly by FONDETEL.
} 
telephone assets that were created prior to 1998 - has also lacked the financial resources to make any further investments.

Second, in addition to these privatization related initiatives, the existing social funds-principally FSDC, FIS and FONAPAZ - increased their investments efforts in the infrastructure sectors (Figure 2.1). Overall, the investments of these three funds in energy, water and sanitation services more than quadrupled between 1996 and 1998. However, this reflected an overall increase in social fund expenditure; rather than a shift in the portfolio of projects towards infrastructure sectors. Moreover, there is evidence that the water, sanitation and electricity investments of social funds have begun to tailoff since 1999.

Figure 2.1: Total social fund investments in rural infrastructure since 1993

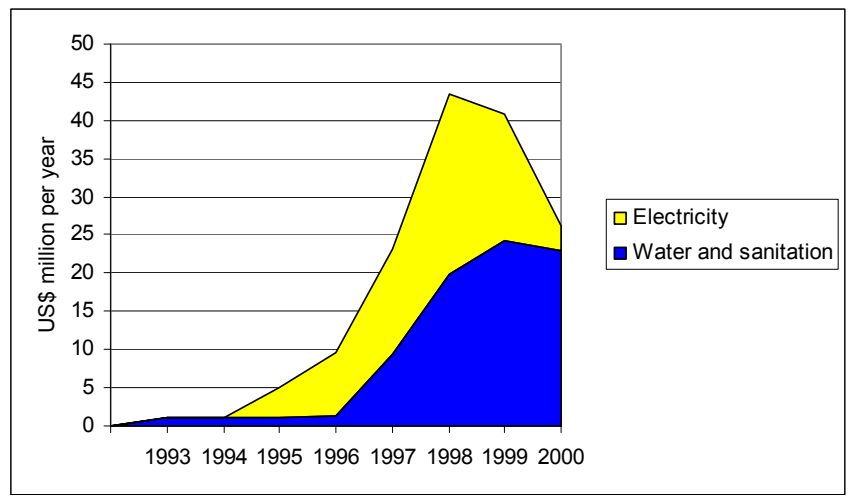

Sources: FIS, FONAPAZ, FSDC

It is interesting to explore the relative importance of resources generated by the privatization process, those channeled via the social funds, and other sources of finance for rural expansion of utility services (Table 2.4). By far the largest volume of resources has gone to water and sanitation, US\$153 million, versus US\$99 million for electricity and US\$7.5 million for public telephones.

In electricity, the volume of resources devoted to rural electrification tripled in the years before and after the Peace Accords. As well as this overall increase, the composition of financing has changed substantially. Up until 1996, about two thirds of the investment in rural electrification came from the state-owned operator INDE, whose program has since been dramatically reduced in scale. This reduction has been more than offset by a quadrupling of social fund investments, and by the beginning of the PER. The latter, which has only disbursed about $20 \%$ of its programmed expenditure to date, will become increasingly important over time as social fund investments appear to be tailing-off.

In telecommunications, the rural investment activities of GUATEL were substantial prior to the Peace Accords but came to a halt following the privatization and sector restructuring exercise that divested the state-owned company of all its assets except for the rural telephones, thereby curtailing its ability to finance further projects. While GUATEL continued to operate existing rural telephones, FONDETEL became responsible for constructing further rural telephones, which it did by contracting with private sector operators. The FONDETEL program rapidly succeeded in almost doubling the number of rural public telephones (from 2,000 to 3,600) in a very short period, with a fraction of the resources absorbed by GUATEL in the earlier period (US\$7.5 million versus US\$46.0 million), largely due to its ability to leverage private capital. 
Table 2.4: Summary of rural infrastructure initiatives since 1996

\begin{tabular}{|c|c|c|c|c|}
\hline Sector & Initiative & Description & $\begin{array}{c}\text { Funds } \\
\text { Invested } \\
\text { (US\$ million) } \\
1993-1996\end{array}$ & $\begin{array}{c}\text { Funds } \\
\text { Invested } \\
\text { (US\$ million) } \\
1997-2000\end{array}$ \\
\hline \multirow[t]{3}{*}{ Electricity } & PER & $\begin{array}{l}\text { - Programa de Electrificación Rural: A program incorporated } \\
\text { into the concession contracts of the two non-metropolitan } \\
\text { distribution companies (DEORSA and DEOCSA). The two } \\
\text { companies are required to extend grid access to } 280,000 \\
\text { households in } 2,700 \text { communities over the period } 2000 / 05 \text {. The } \\
\text { property of the assets financed by PER will revert to the state. } \\
\text { INDE will be responsible for operating transmission assets, } \\
\text { and DEORSA and DEOCSA for the distribution assets. About } \\
\text { a quarter of the target communities are in the department of } \\
\text { Quiche, and the average size of the communities is around } 500 \\
\text { inhabitants. The total cost of US } \$ 333 \text { million, will be financed } \\
\text { in part by the net proceeds of privatizing DEORSA and } \\
\text { DEOCSA (US } \$ 110 \text { million). }\end{array}$ & $\begin{array}{c}32.6 \\
0.0\end{array}$ & $\begin{array}{l}99.0 \\
36.1\end{array}$ \\
\hline & FSDC & $\begin{array}{l}\text { - Fondo de Solidaridad para el Desarrollo Comunitario: The } \\
\text { largest of the country's three main social funds, financed } \\
\text { primarily financed by central government, and providing a } \\
\text { range of services requested by communities including } \\
\text { electrification. Covers mainly rural communities. }\end{array}$ & 12.2 & 57.3 \\
\hline & INDE & $\begin{array}{l}\text { - Instituto Nacional de Electrificación. The statutes of the } \\
\text { company require that it devotes any operating surplus to rural } \\
\text { electrification projects. These have tended to involve mini-grid } \\
\text { projects and grid extensions for communities close to the } \\
\text { Mexican border. }\end{array}$ & 20.4 & 5.6 \\
\hline \multirow[t]{2}{*}{ Telephony } & FONDETEL & $\begin{array}{l}\text { - Fondo de Telecomunicaciones: A fund established from the } \\
\text { proceeds of spectrum license auctions. Bids out minimum } \\
\text { subsidy concessions for private operators to build and operate } \\
\text { public telephones in rural communities. }\end{array}$ & $\begin{array}{c}46.0 \\
0.0\end{array}$ & $\begin{array}{l}7.5 \\
7.5\end{array}$ \\
\hline & GUATEL & $\begin{array}{l}\text { - Guatemala Telecom. The state-owned enterprise that owns } \\
\text { and operates the state's network of rural public telephones. } \\
\text { During the period } 1993-96 \text {, the company invested } \$ 46 \text { million } \\
\text { with finance from IDB and EXIMBANK to provide services } \\
\text { to } 1,150 \text { rural communities. Lack of investment finance has } \\
\text { prevented further progress since privatization, although a new } \\
\text { project for 1,324 rural communities is in process to be } \\
\text { financed by FONAPAZ and BCIE. }\end{array}$ & 46.0 & 0.0 \\
\hline \multirow[t]{5}{*}{$\begin{array}{l}\text { Water and } \\
\text { Sanitation }\end{array}$} & & & NA. & 153.1 \\
\hline & FIS & $\begin{array}{l}\text { - Fondo de Inversión Social: One of the country's largest three } \\
\text { social funds, financed predominantly by international donors, } \\
\text { providing a range of services requested by communities } \\
\text { including water and sanitation. Covers primarily rural } \\
\text { communities. }\end{array}$ & 0.4 & 29.6 \\
\hline & FONAPAZ & $\begin{array}{l}\text { - Fondo Nacional para la Paz: One of the country's largest three } \\
\text { social funds, financed predominantly by international donors, } \\
\text { providing a range of services requested by communities } \\
\text { including water and sanitation. Focuses on areas that were } \\
\text { most affected by the armed conflict. }\end{array}$ & 4.1 & 7.8 \\
\hline & & - Fondo de Solidaridad para el Desarrollo Comunitario. & & 64.4 \\
\hline & UNEPAR & $\begin{array}{l}\text { - Unidad de Proyectos de Acueductos Rurales: The public entity } \\
\text { responsible for finance and TA to rural water projects. In 1997, } \\
\text { was transfered from the Ministry of Health to the Instituto de } \\
\text { Fomento Municipal (INFOM). Finance comes from IDB and } \\
\text { KFW among others. }\end{array}$ & NA. & 51.3 \\
\hline
\end{tabular}


In water and sanitation, the investments made by the social funds since the Peace Accords represented about two thirds of the total, with the remainder being supplied by the central government's rural water program UNEPAR. The total value of UNEPAR's investments in the years prior to the Peace Accords is not known, however they are unlikely to have been as high as those currently allocated by the social funds, and hence overall it seems likely that the volume of resources devoted to rural water and sanitation project has increased substantially.

\section{Impact on Service Coverage}

\subsection{The coverage situation ${ }^{13}$}

The current coverage situation in Guatemala, as portrayed by the ENCOVI survey, is summarized in Table 3.1. Sanitation (broadly defined to include latrines, septic tanks and sewerage) is the service with the highest level of coverage, followed by electricity, water, sewerage and telephony. The gaps between urban and rural coverage are lowest for sanitation, and highest for sewerage and telephony. Water and sanitation are those with the most egalitarian distribution, while sewerage and telephony are the least egalitarian.

Table 3.1: Coverage of utilities (service by service)

(Proportion of households)

\begin{tabular}{l|c|c|c|c|c|c|c|c}
\hline & \multirow{2}{*}{ National } & \multicolumn{2}{|c|}{ By area } & \multicolumn{5}{c}{ By quintile } \\
\cline { 2 - 9 } & & Urban & Rural & 1 & 2 & 3 & 4 & 5 \\
\hline Electricity & .73 & .95 & .56 & .39 & .64 & .78 & .90 & .95 \\
Water & .69 & .88 & .54 & .50 & .62 & .63 & .76 & .92 \\
Sanitation & .87 & .97 & .79 & .73 & .80 & .88 & .95 & .98 \\
Sewerage & .38 & .76 & .09 & .06 & .18 & .32 & .54 & .81 \\
Fixed telephone & .15 & .31 & .03 & .003 & .01 & .03 & .14 & .58 \\
Cellular telephone & .10 & .18 & .03 & .001 & .01 & .03 & .11 & .34 \\
Community public telephone & .64 & .89 & .44 & .37 & .53 & .65 & .79 & .83 \\
\hline \multicolumn{2}{r}{ No service = lack of all network services and latrine. }
\end{tabular}

Network services = electricity, piped water in dwelling or field, telephone (fixed or cellular), and toilet connected to sewerage. Source: World Bank calculations using the ENCOVI 2000, Instituto Nacional de Estadística - Guatemala

While it is conventional to report separate statistics on the coverage of different services, in terms of understanding quality of life, it is informative to consider the combinations of utilities services that people have access to (Table 3.2). The results show that one in six Guatemalan households has no access to any modern network services (electricity, piped water, sewerage or telephony). In rural areas the proportion rises to almost one in three; while in the lowest consumption quintile it is as high as two in five. At the other end of the spectrum, one in six Guatemalan households has access to all four network services, with the ratio rising to one in three for urban areas.

It is interesting to question which is the first service to reach those Guatemalan households that only have access to one of the network services (Table 3.3). The statistics show that in about $60 \%$ of cases the only service available in the household is electricity, and in the other $40 \%$ of cases water. The greater prevalence of electricity services holds good for almost every sub-category of the population except for the poorest. Where only two services are available, they are invariably water and electricity, while households with only three services most typically have electricity, water and sewerage.

\footnotetext{
${ }^{13}$ See Annex D for definitions of coverage, takeup, and availability.
} 
Table 3.2: Coverage of utilities (in combination)

(Proportion of households)

\begin{tabular}{l|c|c|c|c|c|c|c|c}
\hline & \multirow{2}{*}{ National } & \multicolumn{2}{|c|}{ By area } & \multicolumn{5}{|c}{ By quintile } \\
\cline { 3 - 9 } & & Urban & Rural & 1 & 2 & 3 & 4 & 5 \\
\hline No network service & .16 & .02 & .27 & .39 & .21 & .15 & .06 & .02 \\
One network service & .23 & .09 & .34 & .33 & .32 & .29 & .27 & .04 \\
Two network services & .28 & .22 & .32 & .26 & .37 & .34 & .32 & .11 \\
Three network services & .18 & .34 & .06 & .02 & .09 & .20 & .31 & .27 \\
Four network services & .15 & .32 & .01 & .001 & .01 & .03 & .14 & .56 \\
\hline
\end{tabular}

No service $=$ lack of all network services and latrine

Network services = electricity, piped water in dwelling or field, telephone (fixed or cellular), and toilet connected to sewerage.

Source: World Bank calculations using the ENCOVI 2000, Instituto Nacional de Estadística - Guatemala

Table 3.3: Specific combinations of utility services

(Proportion of households)

\begin{tabular}{l|c|c|c|c|c|c|c|c}
\hline & \multirow{2}{*}{ National } & \multicolumn{2}{|c|}{ By area } & \multicolumn{4}{c}{ By quintil } \\
\cline { 3 - 8 } & & Urban & Rural & 1 & 2 & 3 & 4 & 5 \\
\hline One network service & 1.00 & 1.00 & 1.00 & 1.00 & 1.00 & 1.00 & 1.00 & 1.00 \\
Electricity & .57 & .79 & .53 & .34 & .52 & .75 & .78 & .69 \\
Water & .42 & .19 & .47 & .65 & .47 & .25 & .22 & .25 \\
Phone & .004 & .01 & .003 & 0 & .01 & 0 & 0 & .06 \\
Sewerage & .001 & .01 & 0 & .001 & .002 & .002 & 0 & 0 \\
& & & & & & & & \\
Two network services & 1.00 & 1.00 & 1.00 & 1.00 & 1.00 & 1.00 & 1.00 & 1.00 \\
Electricity and water & .93 & .88 & .95 & .99 & .97 & .97 & .84 & .72 \\
Electricity and phone & .04 & .07 & .02 & 0 & .002 & .004 & .10 & .14 \\
Electricity and sewerage & .02 & .03 & .01 & 0 & .01 & .01 & .04 & .04 \\
Water and phone & .01 & 0 & .01 & 0 & .01 & .001 & .01 & .07 \\
Water and sewerage & .01 & .02 & .001 & .01 & .004 & .01 & .01 & .03 \\
Phone and sewerage & 0 & 0 & 0 & 0 & 0 & 0 & 0 & 0 \\
& & & & & & & & \\
Three network services & 1.00 & 1.00 & 1.00 & 1.00 & 1.00 & 1.00 & 1.00 & 1.00 \\
Electricity, water and phone & .19 & .14 & .44 & .11 & .06 & .13 & .16 & .31 \\
Electricity, water and sewerage & .80 & .85 & .53 & .89 & .94 & .87 & .81 & .66 \\
Electricity, phone and sewerage & .01 & .01 & .03 & 0 & 0 & 0 & .02 & .02 \\
Water, phone and sewerage & .005 & .004 & .01 & 0 & 0 & 0 & .004 & .01 \\
\hline
\end{tabular}

Network services are electricity, piped water in dwelling or field, telephone (fixed or cellular), and toilet connected to sewerage.

Source: World Bank calculations using the ENCOVI 2000, Instituto Nacional de Estadística - Guatemala

From the previous figures, it is not possible to say whether the higher prevalence of electricity rather than water in single-service households reflects a preference on the part of the household or simply greater success in rolling out electricity networks versus water networks. In order to shed some light on this question, attention is focused on that subset of the population that live in communities where both services are available (Table 3.4). The results show that such households are twice as likely to choose an electricity connection than a water connection, and that this relationship holds across almost all subcategories, except the first quintile where households are a little more likely to choose the water service. A possible explanation for this is that electricity connections are free of charge, at least in urban areas, whereas water connections entail paying a significant connection fee (see Table 3.14 below).

Table 3.4: Choice between electricity and water

(Proportion of households, among with only one service and in census tract where both water and electricity are available)

\begin{tabular}{c|c|c|c|c|c|c|c|c}
\hline & \multirow{2}{*}{ National } & \multicolumn{2}{|c|}{ By area } & \multicolumn{5}{c}{ By quintile } \\
\cline { 3 - 8 } & & Urban & Rural & 1 & 2 & 3 & 4 & 5 \\
\hline Electricity & .63 & .69 & .60 & .44 & .59 & .76 & .79 & .63 \\
\hline
\end{tabular}


Water

.31

Source: World Bank calculations using the ENCOVI 2000, Instituto Nacional de Estadística - Guatemala 
Another way of exploring the relative value that households place on different services is to consider how much extra they are willing to pay to rent a dwelling that —other things being equal— has access to utilities. This rental premium can be estimated using a hedonic function that models rental payments (or estimated rental payments in the case of owner-occupied housing) as a function of the availability of utilities and of a wide range of variables that affect the price of housing (geographical location, quality of construction, size and age of dwelling, facilities). For full details of the model see Table A5 of the Data Annex. The results show that utility services attract statistically significant rental premia, which represent a substantial percentage of the rent. Although the results vary by geographical zone, telephone services typically attract the highest rental premium, followed by electricity and water.

Table 3.5: Rental value of access to modern utility services

\begin{tabular}{l|c|c|c}
\hline & $\begin{array}{c}\text { Metropolitan } \\
\text { (urban and rural) }\end{array}$ & $\begin{array}{c}\text { Urban } \\
\text { (non-Metropolitan) }\end{array}$ & $\begin{array}{c}\text { Rural } \\
\text { (non-Metropolitan) }\end{array}$ \\
\hline Predicted rent in Quetzales & 794 & 379 & 159 \\
Value as a \% of rent & $48 \%{ }^{* * *}$ & & \\
Water & $2 \%$ & $0.3 \%$ & $-1 \%$ \\
Drainage & $9 \%$ & $9 \%{ }^{*}$ & $17 \%{ }^{* *}$ \\
Electricity & $56 \%{ }^{* * *}$ & $31 \%{ }^{* * *}$ & $18 \%{ }^{* * *}$ \\
Telephone & $379^{* * *}$ & $22 \%{ }^{* * *}$ & $32 \%{ }^{* * *}$ \\
Value in Quetzales & 16 & 1 & -2 \\
Water & 72 & $32^{*}$ & $27^{* *}$ \\
Drainage & $447^{* * *}$ & $118^{* * *}$ & $29^{* * *}$ \\
Electricity & $82^{* * *}$ & $51^{* * *}$ \\
Telephone &
\end{tabular}

Notes: Values calculated from the regional-specific hedonic price function estimations.

Significance level of corresponding variables in the hedonic model: ${ }^{* * *} 99 \%$ level. ${ }^{* *} 95 \%$ level, ${ }^{*} 90 \%$ level. Metropolitan includes urban and rural in this region, while urban and rural exclude the Metropolitan region.

Source: World Bank calculations using the ENCOVI 2000, Instituto Nacional de Estadística - Guatemala

\subsection{International context}

To put these findings in an international context, comparable figures are presented for three neighboring Central American countries: El Salvador, Nicaragua and Panama (Table 3.6). Coverage levels in Guatemala lie towards the middle of the range for this peer group; in general, they are somewhat better than those in Nicaragua and El Salvador, but not as good as those in Panama. Finally, the pattern of access to modern utilities across consumption quintiles in Guatemala is very similar to that found in neighboring Central American countries (Figure 3.1). This illustrates that the degree of inequity in access to basic services found in Guatemala is typical of the Central American region.

Table 3.6: Central American comparisons of urban and rural coverage (Percentage of households)

\begin{tabular}{|c|c|c|c|c|c|c|c|c|c|c|c|c|}
\hline & \multicolumn{3}{|c|}{ Electricity } & \multicolumn{3}{|c|}{ Piped water } & \multicolumn{3}{|c|}{ Basic sanitation* } & \multicolumn{3}{|c|}{ Telephone } \\
\hline & Nat'l & Urban & Rural & Nat'l & Urban & Rural & Nat'l & Urban & Rural & Nat'1 & Urban & Rural \\
\hline Guatemala & 70 & 92 & 54 & 69 & 88 & 54 & 87 & 97 & 79 & 20 & 40 & 5 \\
\hline El Salvador & 80 & 95 & 55 & 52 & 69 & 25 & 81 & 85 & 74 & 20 & 32 & 1 \\
\hline Nicaragua & 69 & 91 & 40 & 61 & 95 & 74 & 84 & 95 & 70 & 16 & 16 & 1 \\
\hline Panamá & 79 & 98 & 52 & 86 & 95 & 74 & 93 & 99 & 86 & 41 & 62 & 11 \\
\hline
\end{tabular}

Notes: •Piped water in dwelling or yard. * Includes toilets and latrines. El Salvador and Honduras quintiles based on income aggregate.

Sources: El Salvador (Encuesta de Hogares de Propósitos Múltiples 1997); Guatemala (ENCOVI 2000, Instituto Nacional de Estadística Guatemala); Honduras (Encuesta Nacional de Ingresos y Gastos de los Hogares, 1999); Nicaragua (LSMS 1998-99); Panama (LSMS 1997). 
Figure 3.1: Central American comparisons for equity of coverage (a) Electricity

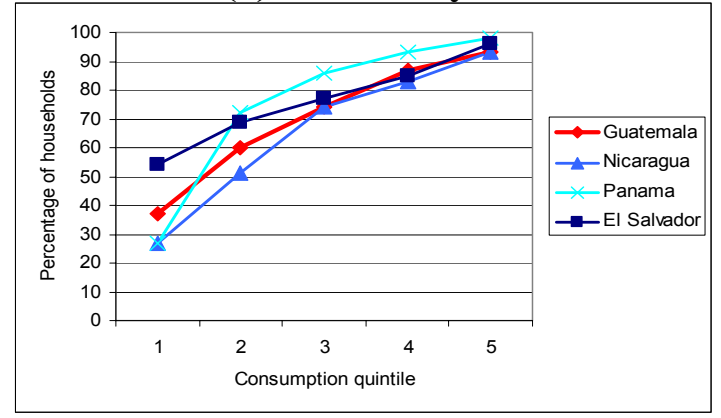

(b) Water

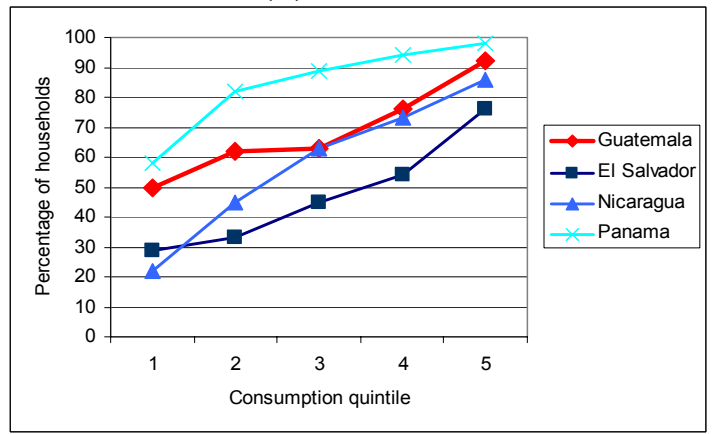

(c) Sanitation

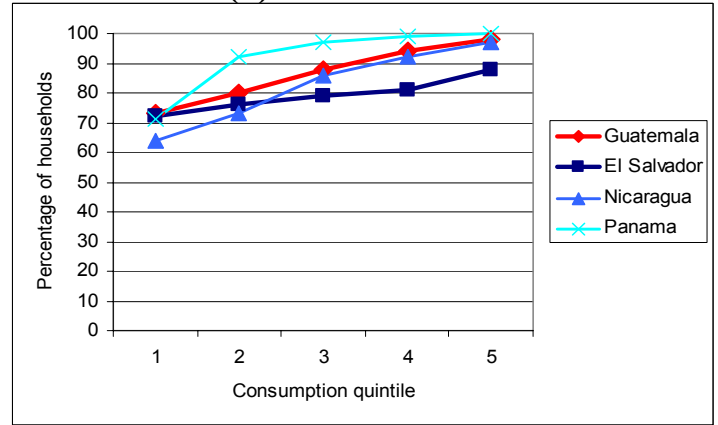

(d) Telephone

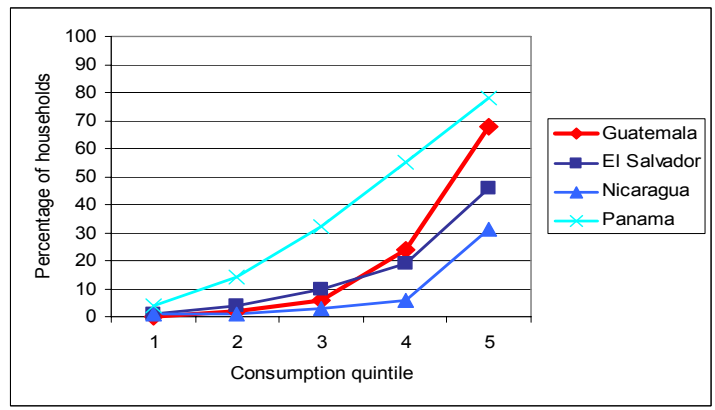

Sources: El Salvador (Encuesta de Hogares de Propósitos Múltiples 1997); Guatemala (ENCOVI 2000, Instituto Nacional de Estadística - Guatemala); Honduras (Encuesta Nacional de Ingresos y Gastos de los Hogares, 1999); Nicaragua (LSMS 1998-99);

Panama (LSMS 1997). 


\subsection{Historical context}

It is important to understand how current levels of coverage have been reached, an in particular the extent to which the greater volume of resources devoted to service expansion following the Peace Accords is reflected as faster growth of coverage.

\section{Expansion of electricity, water and sanitation}

Historical trends show that the rate of increase of coverage accelerated after the major policy changes introduced in $1996^{14}$ (Figure 3.2). For all three services (electricity, water and sanitation), coverage improved by close to 15 percentage points over the subsequent four years (1997-00) compared with just over 10 percentage points over the previous four years $(1993-96)^{15}$. Clearly, it is difficult to attribute the causality for this acceleration to the Peace Accords and to the structural reforms introduced at that time. Other factors - notably economic growth and urbanization-could equally have been at work. Nonetheless, the fact that neither GDP per capita nor urbanization rates increased substantially over this period makes it more likely that the observed improvements were at least partially attributable to changes in the policy environment and increases in public investment ${ }^{16}$.

However, coverage statistics can be misleading because they confound growing numbers of connections with growing population. To disentangle these effects, Table 3.7 reports the absolute number of new connections made in the period before and after the Peace Accords. The results confirm that the rate of service expansion was in general about 50\% higher in the years following the Peace Accords, and that these differences are statistically significant (in most cases at the $99 \%$ level). Furthermore, the acceleration of coverage was quite generalized affecting both urban and rural areas, as well as poor and non-poor populations. Moreover, the changes in the number of new connections per year were largest (in percentage terms) and most significant in the case of poor and rural populations.

On reflection, it is not entirely surprising that new connections went disproportionately to traditionally disadvantaged groups, since most other groups in society were already being served. Therefore, in order to detect whether there has really been an improvement in targeting of services towards socially excluded groups, it is necessary to normalize the number of new connections they received against the size of the corresponding unserved population in each group. In other words, it is necessary to compare the probability that an unserved household in any particular category would become connected during the period immediate preceding and following the Peace Accords (Table 3.8).

\footnotetext{
${ }^{14}$ It is important to explain how this historical series was derived. Due to the paucity of earlier household surveys in Guatemala, the historical series is based on a question in the ENCOVI 2000 survey that asked households to recall the year in which they had first received these services. Hence, the accuracy of the historical trend is contingent on the accuracy of households' recollection. It has been noted in the literature that respondent recall in household surveys can sometimes be affected by a phenomenon known as 'telescoping' whereby events are recalled as being more recent than they actually were. Such a phenomenon, if present, would create the impression that coverage growth had been more rapid in recent years.

${ }^{15}$ Where possible coverage rates derived from the ENCOVI have been compared with official figures. In the case of electricity, the current estimated coverage of $70 \%$ coincides precisely with that reported by the Ministry of Energy. While rural water coverage of $54 \%$ is almost identical to that reported by UNEPAR.

${ }^{16}$ Average GDP per capita was US\$1,449 for 1993/96 and US\$1,532 for 1997/00. While urbanization stood at an average of $38.6 \%$ for $1993 / 96$ and $39.4 \%$ for $1997 / 00$.
} 
Table 3.7: New connections in a three year period before and after the Peace Accord (Number of new connections)

\begin{tabular}{|c|c|c|c|}
\hline & Electricity & $\begin{array}{l}\text { Piped } \\
\text { water }\end{array}$ & Sanitation \\
\hline \multicolumn{4}{|l|}{ National } \\
\hline 1993-1996 & 208,518 & 240,069 & 281,106 \\
\hline $1997-2000$ & $329,734^{* * *}$ & $352,336^{* * *}$ & $350,418^{* *}$ \\
\hline$\%$ change & $58 \%$ & $47 \%$ & $25 \%$ \\
\hline \multicolumn{4}{|l|}{ Urban } \\
\hline 1993-1996 & 92,823 & 109,453 & 134,692 \\
\hline $1997-2000$ & 105,009 & 128,593 & 109,792 \\
\hline$\%$ change & $13 \%$ & $17 \%$ & $-18 \%$ \\
\hline \multicolumn{4}{|l|}{ Rural } \\
\hline 1993-1996 & 115,695 & 130,616 & 146,414 \\
\hline $1997-2000$ & $224,725^{* * *}$ & $223,743^{* * *}$ & $240,626^{* * *}$ \\
\hline$\%$ change & $94 \%$ & $71 \%$ & $64 \%$ \\
\hline \multicolumn{4}{|l|}{ Extreme poor } \\
\hline 1993-1996 & 13,662 & 24,253 & 27,979 \\
\hline $1997-2000$ & $33,135^{* * *}$ & $43,091^{* *}$ & $38,674^{*}$ \\
\hline$\%$ change & $143 \%$ & $78 \%$ & $38 \%$ \\
\hline \multicolumn{4}{|l|}{ All Poor } \\
\hline 1993-1996 & 95,296 & 108,754 & 132,815 \\
\hline $1997-2000$ & $180,842^{* * *}$ & $184,682^{* * *}$ & $176,028^{* *}$ \\
\hline$\%$ change & $90 \%$ & $70 \%$ & $33 \%$ \\
\hline \multicolumn{4}{|l|}{ Non-poor } \\
\hline 1993-1996 & 113,222 & 131,315 & 148,255 \\
\hline $1997-2000$ & $148,892^{*}$ & $167,654^{*}$ & 174,390 \\
\hline$\%$ change & $32 \%$ & $28 \%$ & $18 \%$ \\
\hline \multicolumn{4}{|l|}{ Indigenous } \\
\hline 1993-1996 & 87,785 & 105,547 & 114,052 \\
\hline $1997-2000$ & $142,414^{* * *}$ & $153,789^{* * *}$ & 137,572 \\
\hline$\%$ change & $62 \%$ & $46 \%$ & $21 \%$ \\
\hline \multicolumn{4}{|l|}{ Non-indigenous } \\
\hline 1993-1996 & 117,976 & 133,965 & 166,007 \\
\hline $1997-2000$ & $186,392^{* * *}$ & $195,611^{* * *}$ & $209,926^{*}$ \\
\hline$\%$ change & $58 \%$ & $46 \%$ & $26 \%$ \\
\hline
\end{tabular}

Notes: Based on household recall of the year in which they were first connected

The null hypothesis of equality of the number of users before and after Peace Accord is rejected at: ${ }^{* *} 99 \%$ level. ${ }^{* *} 95 \%$ level, $90 \%$ level.

- Piped water in dwelling or yard. "Includes toilets and latrines.

Source: World Bank calculations using the ENCOVI 2000, Instituto Nacional de Estadística - Guatemala 
Figure 3.2: Historical coverage trends

(a) Electricitv

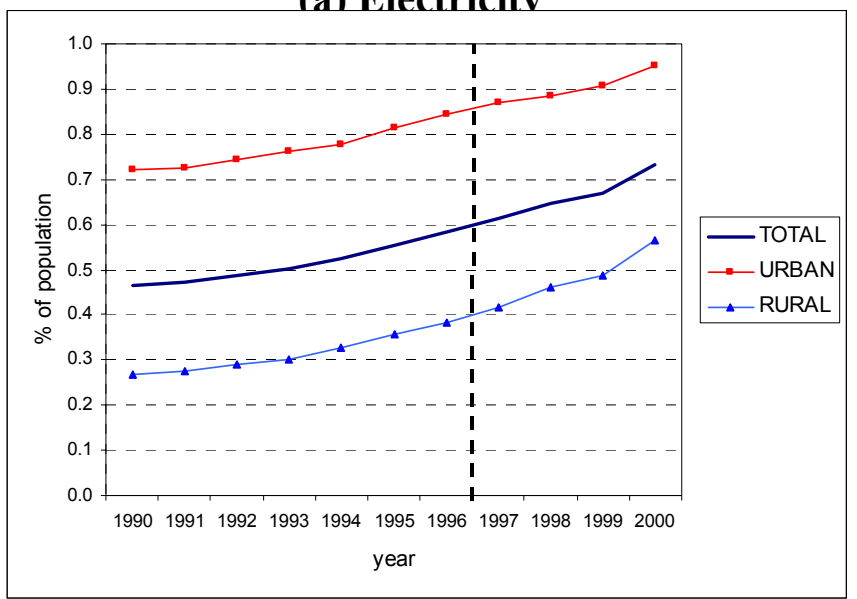

(b) Water

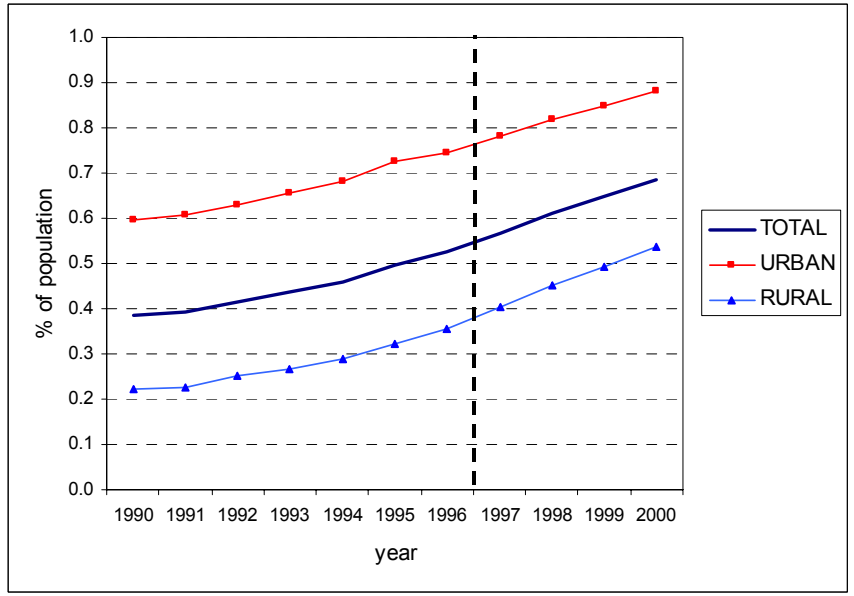

(c) Sanitation

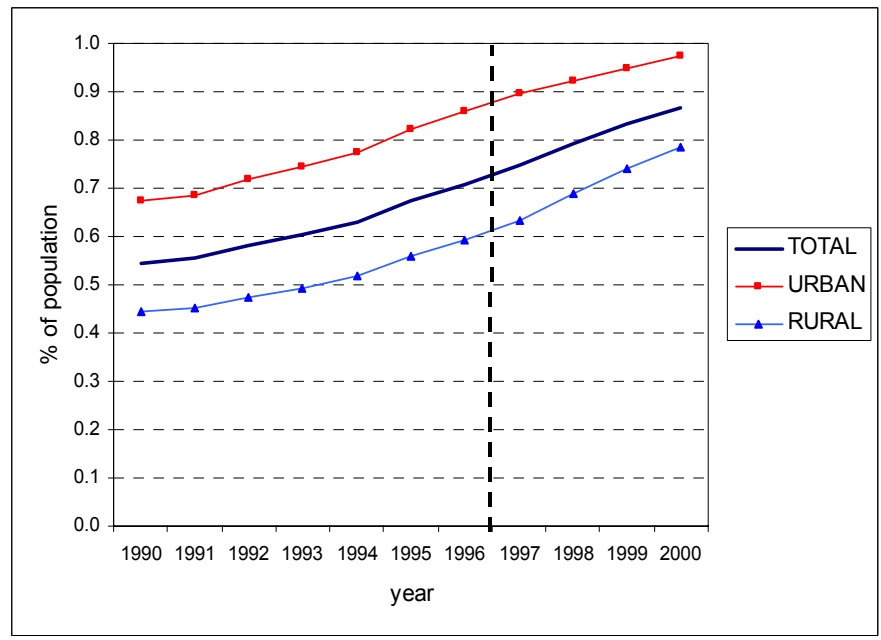

Source: World Bank calculations using the ENCOVI 2000, Instituto Nacional de Estadística - Guatemala 


\section{Table 3.8: Probability that an unserved household was connected}

(Proportion of unserved households receiving a connection)

\begin{tabular}{|c|c|c|c|}
\hline & Electricity & Piped water* & Sanitary services ${ }^{*}$ \\
\hline National & & & \\
\hline 1993-1996 & $.19^{* * *}$ & $.19^{* * *}$ & $.31^{* * *}$ \\
\hline $1997-2000$ & .36 & .34 & .55 \\
\hline$\%$ change & $89 \%$ & $79 \%$ & $77 \%$ \\
\hline Urban & & $21^{* * *}$ & \\
\hline 1993-1996 & .38 & .31 & .50 \\
\hline $1997-2000$ & .70 & .53 & .82 \\
\hline$\%$ change & $84 \%$ & $71 \%$ & $64 \%$ \\
\hline Rural & $.13^{* * *}$ & $.14^{* * *}$ & $.22^{* * *}$ \\
\hline 1993-1996 & $\begin{array}{l}.13 \\
.29\end{array}$ & & \\
\hline $1997-2000$ & $\begin{array}{l}.29 \\
123 \%\end{array}$ & $100 \%$ & $118 \%$ \\
\hline$\%$ change & $123 \%$ & & \\
\hline Extreme poor & $.06^{* * *}$ & $.13^{* * *}$ & $.21^{* * *}$ \\
\hline 1993-1996 & & & .37 \\
\hline 1997-2000 & $183 \%$ & $100 \%$ & $76 \%$ \\
\hline All Poor & & & \\
\hline $1993-1996$ & $.13^{* * *}$ & $.15^{* * *}$ & $.25^{* * *}$ \\
\hline $1997-2000$ & .28 & .29 & .44 \\
\hline$\%$ change & $115 \%$ & $93 \%$ & $76 \%$ \\
\hline Non-poor & & & \\
\hline 1993-1996 & .29 & .24 & .38 \\
\hline $1997-2000$ & .55 & .41 & .72 \\
\hline$\%$ change & $90 \%$ & $71 \%$ & $89 \%$ \\
\hline Indigenous & & & \\
\hline 1993-1996 & .16 & .18 & .30 \\
\hline $1997-2000$ & .30 & .32 & .52 \\
\hline$\%$ change & $88 \%$ & $78 \%$ & $73 \%$ \\
\hline Non-indigenous & & & \\
\hline 1993-1996 & .21 & .19 & .31 \\
\hline $1997-2000$ & $\begin{array}{l}.42 \\
100 \%\end{array}$ & $\begin{array}{l}.35 \\
840\end{array}$ & .57 \\
\hline$\%$ change & $100 \%$ & $84 \%$ & $84 \%$ \\
\hline
\end{tabular}

At a national level, the probability of an unserved household receiving a connection increased by approximately $80 \%$ for electricity, piped water and basic sanitation. All types of households, irrespective of location, poverty or ethnicity experienced a statistically significant increase in the probability of being connected. Moreover, traditionally disadvantaged groups gained disproportionately, increasing their probability of being connected by well over $100 \%$ in most cases. For example, the probability of being connected increased by $183 \%$ for the extreme poor, $115 \%$ for the poor, and $90 \%$ for the non-poor.

However, this disproportionate gain has not been enough to compensate for the lower initial probability of being connected for members of traditionally disadvantaged groups. Thus, notwithstanding the large percentage gains, in absolute terms the probability that a family in extreme poverty receives an electricity connection (at 0.17 ) is still lower than the probability for a family in poverty (at 0.28 ), and substantially lower than that for a non-poor household (0.55). Some indigenous groups also still have a relatively low probability of being connected, in particular the Q'eqchi (for electricity and water). However, other indigenous groups actually have a higher probability than average of receiving a connection, in particular the Ki'che and Kaqchikel (for electricity). 


\section{Expansion of telecommunications}

The ENCOVI survey does not provide information on historical coverage trends for telecommunications at the household level. However, it is possible to trace the evolution of rural public telephones. As of 1996, GUATEL was operating some 2,000 rural public telephones, while FONDETEL added a further 1,600 between 1998/9.

Although, only about a third of the country's 19,000 rural towns have a public telephone service ${ }^{17}$, the ENCOVI reveals that $50 \%$ of rural households have a public telephone in their community. This reflects the fact that the larger rural communities tend to be the first to receive a public telephone. For those living in unserved communities, the average distance to the nearest public telephone was $7.2 \mathrm{~km}$ (or about a 45 minute trip).

Figure 3.3: Distance to public telephone for rural households

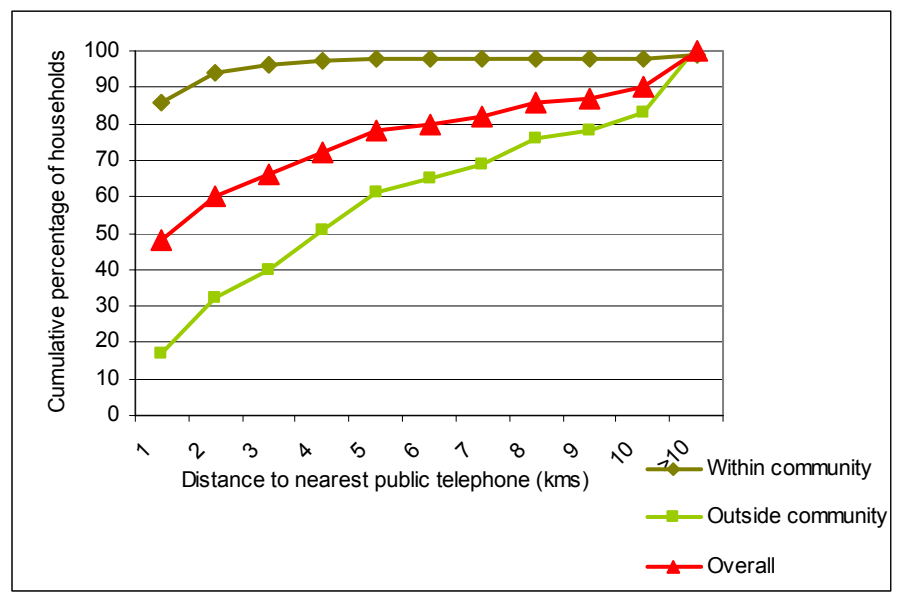

Source: World Bank calculations using the ENCOVI 2000, Instituto Nacional de Estadística - Guatemala

Overall, $80 \%$ of rural households in Guatemala live within $6 \mathrm{~km}$ of a telephone (Figure 3.3). However, the pattern differs significantly by region (Figure 3.4). The North and Northwest of the country, together with Petén, have the worst levels of access to public telephones with average distances of 6-12 km and average journey times of around 50 minutes. By contrast, in all other regions the average distance to a public telephone is less than $5 \mathrm{~km}$ representing typically a half hour trip. Fewer than $10 \%$ of rural households claimed to have spent money on making a public telephone call the day before the survey ${ }^{18}$.

\footnotetext{
${ }^{17}$ Information supplied by FONDETEL.

${ }^{18}$ Unfortunately, the ENCOVI survey groups together expenditure on public telephone calls, faxes and postal services. The percentage reported relates to the number of people who registered non-zero expenditure in this category. Hence, it is very much an upper bound estimate for the proportion of rural households that are using public telephones. However, given the relatively scarce availability of facsimile and postal services in rural areas, it seems probable that quite a high proportion of these expenditures relate to public telephone calls.
} 


\section{Figure 3.4: Accessibility of public telephones for rural households by region}

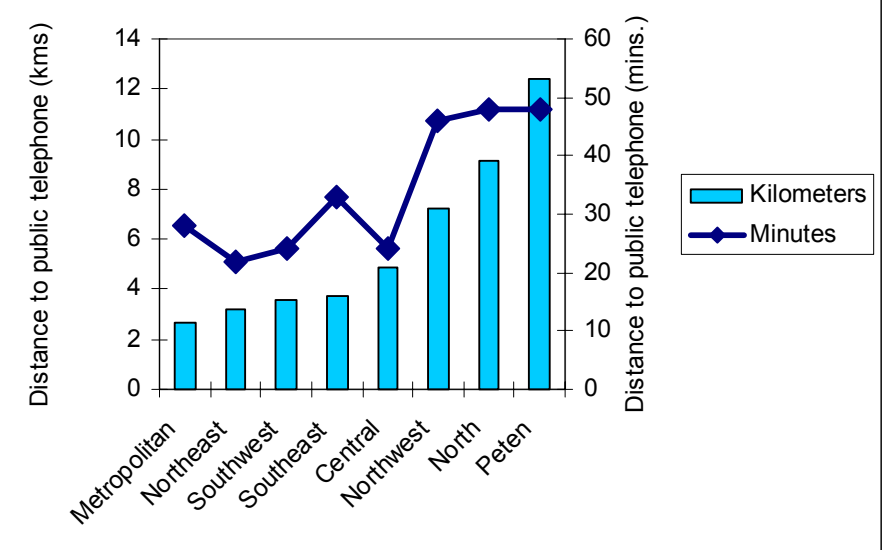

Source: World Bank calculations using the ENCOVI 2000, Instituto Nacional de Estadística - Guatemala

As of 2000, 20\% of households in Guatemala claimed to have access to either a fixed line and/or a cellular telephone, although coverage rates differ substantially between urban areas (40\%) and rural areas $(5 \%)$. About $74 \%$ of Guatemala households continue to obtain their telephone service from TELGUA. With $16 \%$ of the household market, COMCEL is the most significant competitor to TELGUA; it has the second largest fixed lines business in the country, as well as a substantial presence in the cellular market. Moreover, it has developed a particular presence in the rural areas where it is the primary service provider for $29 \%$ of households.

There is a widespread anecdotal perception, not only in Guatemala, but throughout Latin America, that the advent of cellular telephony has helped to 'democratize' the telephone. However, to date, very few household surveys make it possible to distinguish between fixed and cellular telephone ownership. The ENCOVI is unusual in this respect, and hence it is interesting to examine ownership patterns across consumption quintiles (Figure 3.5). The results appear to indicate a high degree of concentration of cellular telephones in higher consumption quintiles, with more than $80 \%$ being held by the top two quintiles. Indeed, about half of all cellular telephones in Guatemala are second telephones belonging to households in the highest consumption quintiles.

However, on closer inspection, cellular telephones have become a very important phenomenon for certain other groups. For example, in the second and third quintiles, although cellular telephones are only held by a small minority, there are in fact equal numbers of households with fixed and cellular telephones. The same is true in rural areas, where there are equal numbers of fixed and cellular subscribers, and where two thirds of the households with cellular telephones have no other telephone service and are hence using the device as a substitute for a fixed line service. This is in contrast to urban areas where fixed telephones still outnumber cellular ones by 1.7 to 1.0 .

Finally, this data may understate the full importance of cellular telephony in rural areas. On an anecdotal basis, the interview teams for the ENCOVI survey reported that cellular telephones are quite widely used to provide an informal public telephone service in rural areas, with the owner of the telephone allowing his neighbors to make calls on a charged out basis. However, unfortunately, it is not possible to corroborate this phenomenon with the ENCOVI data. 
Figure 3.5: Access to fixed and cellular telephones

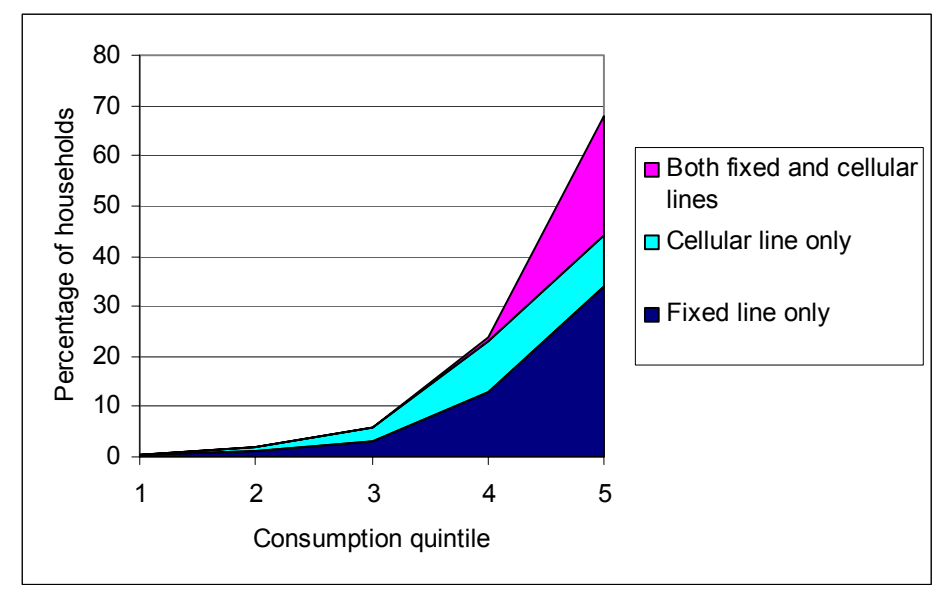

Source: World Bank calculations using the ENCOVI 2000, Instituto Nacional de Estadística - Guatemala

\subsection{The remaining deficit}

Notwithstanding this progress, a significant coverage gap remains (Table 3.9). Well over half a million households are still without electricity and piped water. Some 200,000 are without any form of sanitation, while about 1.3 million rely on latrines as opposed to conventional sewerage. The households that remain unserved are predominantly rural and predominantly poor.

Table 3.9: Coverage gap for modern utilities

(Number of unserved households)

\begin{tabular}{l|r|r|r|r|r}
\hline & \multicolumn{1}{|c|}{ Electricity } & \multicolumn{1}{|c|}{ Piped water* } & \multicolumn{1}{c|}{ Basic sanitation } & Improved sanitation & \multicolumn{1}{l}{ Total no. of households } \\
\hline National & 585,933 & 686,893 & 288,807 & $1,353,895$ & $2,191,451$ \\
By area & & & & \\
Urban & 45,189 & 113,235 & 24,156 & 224,291 & 951,654 \\
Rural & 540,744 & 573,658 & 264,651 & $1,129,604$ & $1,239,797$ \\
By quintile & & & & \\
1 & 266,931 & 220,182 & 116,340 & 411,318 & 438,437 \\
2 & 155,116 & 163,797 & 84,249 & 349,173 & 427,908 \\
3 & 98,428 & 164,199 & 52,064 & 304,708 & 446,068 \\
4 & 44,513 & 104,894 & 25,003 & 203,850 & 442,583 \\
5 & 20,945 & 33,821 & 10,161 & 84,846 & 436,455 \\
\hline
\end{tabular}

Source: World Bank calculations using the ENCOVI 2000, Instituto Nacional de Estadística - Guatemala

From Table 3.7 it can be inferred that the typical annual rate of service expansion at present rates was around 115,000 new connections for electricity, water and sanitation. Given current levels of population growth of around $2.6 \%$ per annum, with this rate of expansion it will take more than eight years to reach universal coverage for all services except for basic sanitation (Table 3.10). Only a doubling of current rates of expansion, or a stabilization of population, would permit universal coverage to be reached in the medium term; that is between 3 to 12 years depending on the service. 
Table 3.10: How far away is universal coverage?

(Anticipated date of universal coverage)

\begin{tabular}{l|c|c}
\hline & $\begin{array}{c}\text { Present effort levels } \\
\text { sustained }\end{array}$ & $\begin{array}{c}\text { Present effort } \\
\text { levels doubled }\end{array}$ \\
\hline Electricity & 2006 & 2003 \\
Water & 2007 & 2004 \\
Basic sanitation & 2003 & 2002 \\
Improved sanitation & 2014 & 2007 \\
\hline
\end{tabular}

Note: It is assumed that population growth remains at historically observed rates of $2.6 \%$ per annum and that household size remains constant.

Based on typical unit costs for service expansion, the total cost of meeting universal coverage across the electricity, water and sanitation services is estimated at US\$1.5 billion (Table 3.11). The electricity service, owing to its relatively high unit cost of US $\$ 1,000$ per household, accounts for over $40 \%$ of this total expenditure, compared with $25 \%$ for piped water. In the case of sanitation, two levels of universal service are defined. The first level is universal basic sanitation, which basically entails providing latrines to the 288,807 households that currently have no form of sanitation, and would cost less than US\$15 million to achieve. The second level is universal improved sanitation. This entails providing sewerage to all households in conurbations with greater than 50,000 population (notably the Metropolitan area, Quetzaltenango, and Escuintla) ${ }^{19}$, and upgrading all other households to a flush toilet with a septic tank. This is a very much more expensive proposition, accounting for almost a third of the overall expansion costs.

Table 3.11: Cost of reaching universal coverage

\begin{tabular}{l|r|r|r|r}
\hline & $\begin{array}{r}\text { Coverage gap } \\
\text { (connections) }\end{array}$ & $\begin{array}{c}\text { Unit cost* } \\
\text { (US\$ per connection) }\end{array}$ & \multicolumn{1}{c}{$\begin{array}{c}\text { Total cost } \\
\text { (US\$) }\end{array}$} & $\begin{array}{c}\text { Share of } \\
\text { total cost }\end{array}$ \\
\hline Electricity & 585,933 & 1,000 & $585,933,000$ & $40.1 \%$ \\
Water & 686,893 & 500 & $343,446,500$ & $23.5 \%$ \\
Basic sanitation & 288,807 & 100 & $28,880,700$ & $2.0 \%$ \\
Improved sanitation & $1,148,702$ & 250 & $287,175,500$ & $19.6 \%$ \\
- Large cities & 205,193 & 750 & $153,894,750$ & $10.5 \%$ \\
- Elsewhere & 585,933 & 1,000 & $585,933,000$ & $40.1 \%$ \\
Public telephones & 12,730 & 5,000 & $63,650,000$ & $4.4 \%$ \\
& & & & $100.0 \%$ \\
\hline
\end{tabular}

* Estimates provided by Kilian Reiche (electricity) and Franz Drees (water and sanitation) from the Finance, Private Sector and Infrastructure Division of the Latin America and Caribbean Region of the World Bank

In the case of water and sewerage services, international experience suggests that the costs of universalizing access could be reduced by as much as $40 \%$ if innovative 'condominial' designs are adopted and implemented through community participation (Foster, 2001). The 'condominial' approach to water and sewerage networks was pioneered in Brazil in the 1980s and has recently been applied with some success in Bolivia. The approach involves altering the engineering design of the water or sewerage network so that instead of providing a separate branch from the main network to each household, a single branch is provided to a whole block (or 'condominium') of households, who then make their connections along this common branch. This saves costs by reducing the length, diameter and depth of

\footnotetext{
${ }^{19}$ For the purposes of this analysis it was only possible to estimate the coverage deficit for the Metropolitan region.
} 
the network needed to serve a given community, costs are further reduced by relying on community volunteer labor to construct the systems.

\subsection{Obstacles to expanding coverage ${ }^{20}$}

In order to develop a strategy for reaching unserved households, it is important to understand the reasons why these households remain unconnected at present. Broadly speaking, there are two possible explanations. The first explanation is that the service is simply not available in the communities where they live; this is essentially a supply-side problem that requires increased investment in infrastructure expansion. The second explanation is that the households fail to take-up the service even when it is available in the community; this is essentially a demand-side problem that may be less costly to overcome in investment terms, but is perhaps more complex to deal with requiring a careful diagnosis and considered policy response.

It is possible to capture this difference by comparing two indices (Table 3.12). The availability index gives the percentage of households that live in communities where the service is available, while the uptake index shows the percentage of households who live in communities where the service is available who actually connect to the service ${ }^{21}$. The results show that electricity has the highest uptake index of any of the services at $88 \%$, followed by water, sewerage and fixed telephone. Not only are services more likely to be available in urban areas, but urban households are substantially more likely to take-up these services when they are available.

Table 3.12: Comparison of availability and uptake of services

\begin{tabular}{|c|c|c|c|c|c|c|c|c|c|c|c|c|}
\hline & \multicolumn{3}{|c|}{ Electricity } & \multicolumn{3}{|c|}{ Piped water } & \multicolumn{3}{|c|}{ Sewerage } & \multicolumn{3}{|c|}{ Fixed telephone } \\
\hline & Nat'l & Urban & Rural & Nat'1 & Urban & Rural & Nat'l & Urban & Rural & Nat'1 & Urban & Rural \\
\hline Availability & 83 & 100 & 70 & 81 & 95 & 70 & 51 & 91 & 20 & 36 & 68 & 11 \\
\hline Uptake & 88 & 95 & 81 & 85 & 92 & 76 & 75 & 85 & 44 & 42 & 46 & 24 \\
\hline Coverage & 73 & 95 & 56 & 69 & 88 & 54 & 38 & 76 & 09 & 15 & 31 & 03 \\
\hline
\end{tabular}

Notes: 'Piped water in dwelling or yard. See Annex D for definitions and calculations of Availability, Uptake, and Coverage.

Source: World Bank calculations using the ENCOVI 2000, Instituto Nacional de Estadística - Guatemala

Using these indices it is possible to calculate what proportion of the coverage deficit currently observed in Guatemala is attributable to supply-side or demand-side factors (Figure 3.7) ${ }^{22}$. The results indicate that, depending on the service, $20 \%$ to $40 \%$ of the coverage gap is related to purely demand-side factors and could be resolved without major investments in network expansion. Between $10 \%$ and $50 \%$ of the coverage gap, depending on service, would require both physical expansion and demand-side measures.

\footnotetext{
${ }^{20}$ See Annex D for an explanation of the definitions of coverage, take-up, and availability.

21 It is important to clarify the definition of 'community'. The sampling frame of the ENCOVI 2000 was based on 'unidades primarias de muestro', which are blocks of 50 contiguous households from which 10-12 households were sampled by the survey.

${ }^{22}$ This breakdown is undertaken as follows. Households who live in communities where the service is available but who do not connect are counted as a demand-side only problem. For communities where the service is not currently available, the average take-up rate observed elsewhere in the country is applied to determine how many of these households could be expected to connect if the service were made available. These households are counted as a supply side only problem. All remaining households are counted as both a demand-side and a supply-side problem.
} 
It is important to note that the cost estimates for universal coverage that were presented above were based on the assumption that new infrastructure investments would be needed to reach all households that are currently unserved. (Table 3.11). The analysis of the coverage deficit suggests that this is not in fact the case, and that a significant part of the coverage gap could be bridged by removing barriers that prevent households connecting to existing networks. Overall, it is estimated that this factor could reduce the cost of meeting universal access by as much as 30\%, from US $\$ 1.4$ billion to US\$ 1.0 billion.

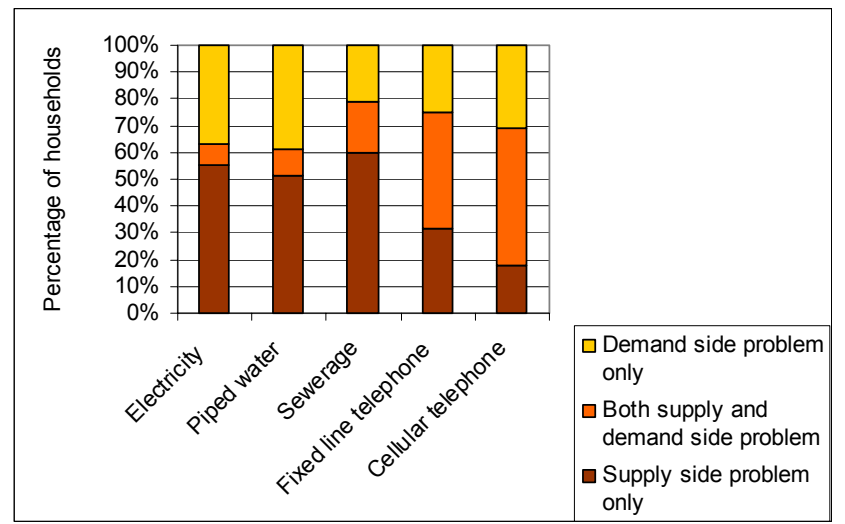

Figure 3.7: Decomposition of coverage deficit

\author{
Notes: "Piped water in dwelling or yard. \\ Source: World Bank calculations using the ENCOVI 2000, Instituto Nacional de Estadística - Guatemala
}

In order to understand the correlations between specific household characteristics and the decision of whether to connect to a utility service that is already available in the community, a probit regression is used to control for other economic, cultural and geographic variables that may be related with the decision to connect to a service (Table 3.13).

Table 3.13: Take-up of modern utilities and household characteristics

(Marginal effects from probit regression are reported)

\begin{tabular}{|c|c|c|c|c|c|c|}
\hline Variable & Electricity & Water & Sanitation & Sewerage & Fixed Phone & Cell Phone \\
\hline Household head characteristics & & & & & & \\
\hline Male & $-.021^{* *}$ & $-.027^{* *}$ & -.003 & $-.081^{* * *}$ & -.047 & .047 \\
\hline Age & $5 \times 10^{-4 *}$ & $.001^{* * *}$ & $7 \times 10^{-4 * * *}$ & .001 & $.011^{* * *}$ & $-.002^{* *}$ \\
\hline Years of school & $.011^{* * *}$ & $.013^{* * *}$ & $.008^{* * *}$ & $.015^{* * *}$ & $.035^{* * *}$ & $.021^{* * *}$ \\
\hline Indigenous & -.016 & -.004 & $.018^{* *}$ & $-.067^{* *}$ & $-.079^{*}$ & -.046 \\
\hline Speaks Spanish & .026 & .010 & .016 & .010 & $-.214^{*}$ & .027 \\
\hline Household characteristics & & & & & & \\
\hline Business in dwelling & $.035^{* * *}$ & .004 & .009 & .009 & $.085^{* *}$ & .026 \\
\hline Income & .003 & $.007^{* * *}$ & $.007^{* * *}$ & $.013^{* * *}$ & $.025^{* * *}$ & $.007^{* * *}$ \\
\hline Urban area & $.056^{* * *}$ & $.052^{* * *}$ & $.063^{* * *}$ & $.280^{* * *}$ & -.015 & $-.071^{* * *}$ \\
\hline Regional dummies & & & & & & \\
\hline Metropolitan & $.043^{*}$ & .024 & .007 & .022 & -.064 & .042 \\
\hline North & $-.041^{*}$ & -.038 & $.031^{* * *}$ & -.059 & $-.160^{* * *}$ & -.039 \\
\hline Northeast & $.031^{*}$ & -.064 & $-.054^{* *}$ & -.106 & -.034 & -.010 \\
\hline Southeast & .021 & -.024 & $-.059^{* * *}$ & -.011 & -.033 & -.032 \\
\hline Central & .019 & -.027 & .008 & $.081^{* * *}$ & -.080 & -.020 \\
\hline Southwest & .023 & .013 & .002 & $.083^{* *}$ & -.035 & -.016 \\
\hline Petén & $-.070^{* *}$ & .020 & $-.080^{* * *}$ & $-.595^{* * *}$ & -.065 & .009 \\
\hline $\mathrm{F} \quad(15,1043)$ & 15.05 & 10.60 & 13.79 & 12.73 & 34.09 & 13.08 \\
\hline Observations & 6,058 & 6,034 & 7,144 & 3,796 & 2,761 & 2,592 \\
\hline Population size & $1,802,063$ & $1,764,457$ & $2,137,789$ & $1,098,917$ & 781,336 & 826,134 \\
\hline
\end{tabular}


The model suggests that households headed by men are significantly less likely to connect to electricity, water, and sewerage services. The propensity to connect to all services increases significantly with years of education of the head of household. Furthermore, households headed by an indigenous person are substantially less likely to be connected to sewerage and fixed telephony services. The presence of a business in the dwelling is significantly correlated to being connected to the electricity network, and particularly to having fixed line telephone service, where there is an impact of 8.5 percentage points.

Monthly household expenditure also is significantly correlated with the take-up of all modern utilities, with the exception of electricity. This finding suggests that connection charges for all services may represent a barrier for lower income households. Indeed, the charges levied for connection to all services, except for electricity in urban areas, represent a substantial proportion of the monthly poverty line (Table 3.14). Furthermore, it is important to note that the cost of connecting to utility services goes beyond the connection charge. There is often a substantial complementary investment that must be made in adapting the dwelling to the new service. For example, internal wiring for electricity can cost around US\$100, while internal plumbing for water and sewerage can cost several hundred dollars.

Table 3.14: Affordability of connection charges

\begin{tabular}{l|c|c|c|c}
\hline & Electricity & Piped water & Sewerage & Fixed telephone \\
\hline Connection charge (US\$) & Urban: None & $\begin{array}{c}\text { EMPAGUA } \\
250 \\
\text { Rural areas } \\
\text { Rural: varies } \\
\text { by project } \\
\text { but can be } \\
\text { substantial }\end{array}$ & $\begin{array}{c}\text { Rural areas } \\
<25\end{array}$ & 350 \\
& 0 & $\begin{array}{c}\text { EMPAGUA } \\
104\end{array}$ & \\
$\begin{array}{l}\text { Connection charge as a percentage } \\
\text { of the budget of a 5 person } \\
\text { household living exactly on the } \\
\text { poverty line (\%) }\end{array}$ & & $\begin{array}{c}\text { Rural areas } \\
<42\end{array}$ & $\begin{array}{c}\text { TELGUA } \\
146\end{array}$ \\
\hline
\end{tabular}

Source: CNE, TELGUA, IADB

Finally, people living in urban areas are significantly more likely to be connected to all, except fixed phone services. This difference is exceptionally high in the case of sewerage. There are two possible explanations for this. The first is that utilities may find it particularly easy to respond to connection requests in the urban areas, and specifically the capital city, than in remote areas. The second is that the greater prevalence of services in urban areas, and especially the metropolitan area, may create other types of neighborhood effects that will lead households to connect (e.g. social pressure, lower information costs, free riding from neighbors' lobbying efforts, etc.).

\section{Affordability of Modern utilities}

Evidently, there is little value in having access to a utility service if a household is unable to meet the corresponding bills. The Guatemalan government has been very conscious of the potential political and social ramifications of the tariff increases that typically result from private sector participation and sector reform. In the electricity sector, this has meant introducing socially motivated ceilings on residential tariffs. While, in the water sector, the unwillingness to raise tariffs to anything approaching cost recovery levels has been a significant barrier to reform. However well-intentioned these policies 
may have been, there is significant evidence that they are not particularly successful in protecting poor households, and that they can have undesirable consequences.

To put these matters into context, households in Guatemala spend around $10 \%$ of their household budget on water, energy and telecommunications services. Over $50 \%$ of this expenditure goes on energy for cooking and heating, and over $25 \%$ goes on energy for lighting and powering appliances, while barely $0.5 \%$ of income is spent on water services. The overall budget share is relatively constant across consumption quintiles, although the composition of the budget shifts away from cooking fuels and towards telecommunications for richer households (Figure 4.1). Although only a tiny fraction of the poorest households have access to telephones, those that do so spend as much as $5 \%$ of their income on the service.

Figure 4.1: Expenditure on modern utilities as a percentage of consumption

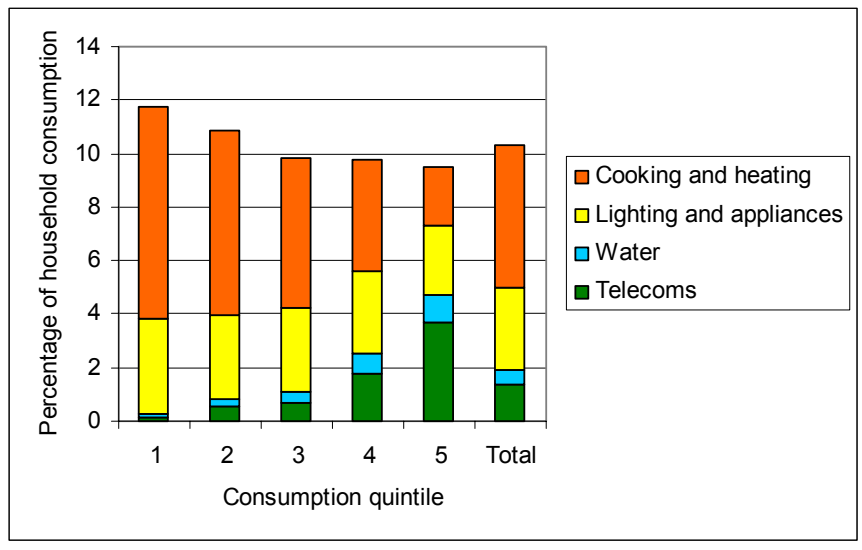

Source: World Bank calculations using the ENCOVI 2000, Instituto Nacional de Estadística - Guatemala

\subsection{Electricity}

As a consequence of the electricity reforms, the newly privatized distribution companies were allowed to pass on to customers the changes in the cost of purchasing energy. Since Power Purchase Agreements signed between generators and distributors were indexed to the US\$ and the price of oil, prices began to rise substantially from the end of 1998 (Figure 4.2). EEGSA experienced the steepest rises, with tariffs increasing $85 \%$ over the three year period 1998/01. While for DEORSA and DEOCSA the increases were somewhat lower at 55\%-60\%.

In order to protect domestic consumers from rising electricity prices, the government introduced a social tariff ('tarifa social'), which held the price of electricity at around US\$0.08 per $\mathrm{kWh}$ for all residential customers consuming up to $500 \mathrm{kWh}$. The cost of this subsidy, estimated at over US\$57 million per year, was met by INDE on the basis of state transfers. It is noteworthy that even with the social tariff, about a quarter of all complaints received from consumers by the regulatory agency CNEE during 2000 are about tariffs being excessively high. 


\section{Figure 4.2: Evolution of electricity tariffs following reform}

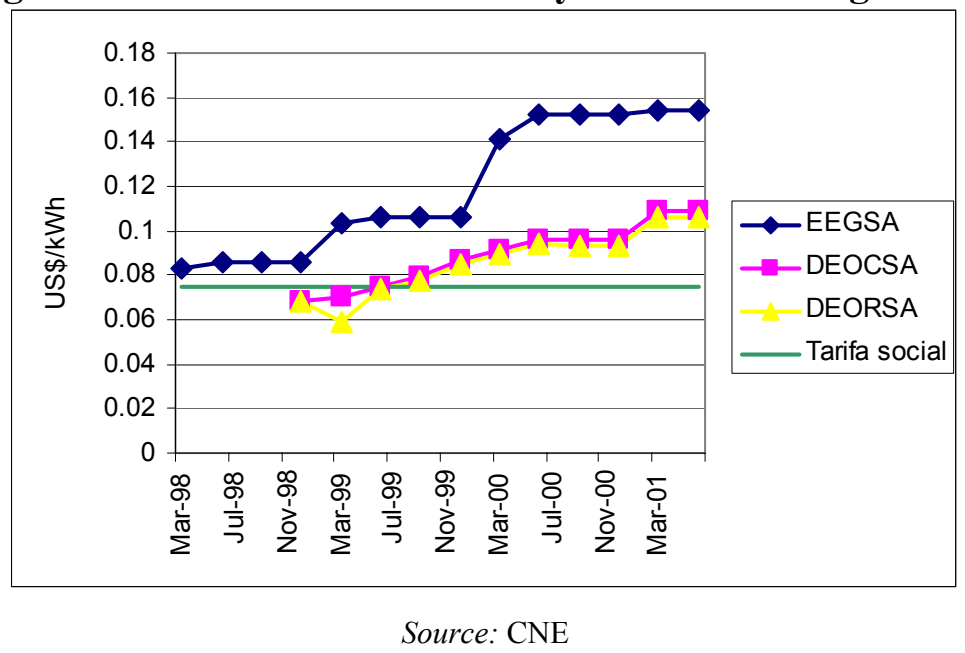

A new law passed in January 2001 made a number of changes to the social tariff, designed to reduce the associated fiscal burden and provide a more objective basis for determining and revising the level of the tariff. The new law reduced the threshold of eligibility from $500 \mathrm{kWh}$ per month to $300 \mathrm{kWh}$ per month, leading to an estimated cost saving of US\$7.1 million annually. It also obliged distributors to tender out the purchase of power for the express purpose of meeting this 'social demand'. The idea is to allocate supply from the lowest marginal cost power plants (typically hydroelectric) to this category of domestic customers, while leaving more expensive power from mid-merit thermal plants to cover demand from largest domestic, as well as commercial and industrial, customers. Effectively, this approach has done away with the need for direct government finance of the subsidy, by creating a cross-subsidy between customer categories.

The thresholds that have been set for social tariffs are very high in relation to typical residential consumption (Figure 4.3). The average household consumes $102 \mathrm{kWh}$ per month, with poor households consuming $48 \mathrm{kWh}$ per month on average and non-poor households consuming $128 \mathrm{kWh}$ per month. As a result, $99 \%$ of residential customers qualified for the social tariff under the original scheme. Following the recent reforms, this percentage fell only slightly to $94 \%$, reflecting the fact that relatively few households consume in the bracket $300-500 \mathrm{kWh}$ per month.

In terms of affordability, the effect of the current social tariff is to reduce the proportion of the household budget devoted to electricity from $3.7 \%$ to $2.7 \%$ for poor households, and from $4.1 \%$ to $2.6 \%$ for non-poor households ${ }^{23}$.

\footnotetext{
${ }^{23}$ In practice, this is an over-estimate since it assumes zero price elasticity. If households, who currently benefit from the social tariff were faced with the true cost of electricity, they would presumably adjust by reducing their level of demand and hence the proportion of budget allocated to electricity would be somewhat lower than indicated.
} 


\section{Figure 4.3: Cumulative density of electricity consumption}

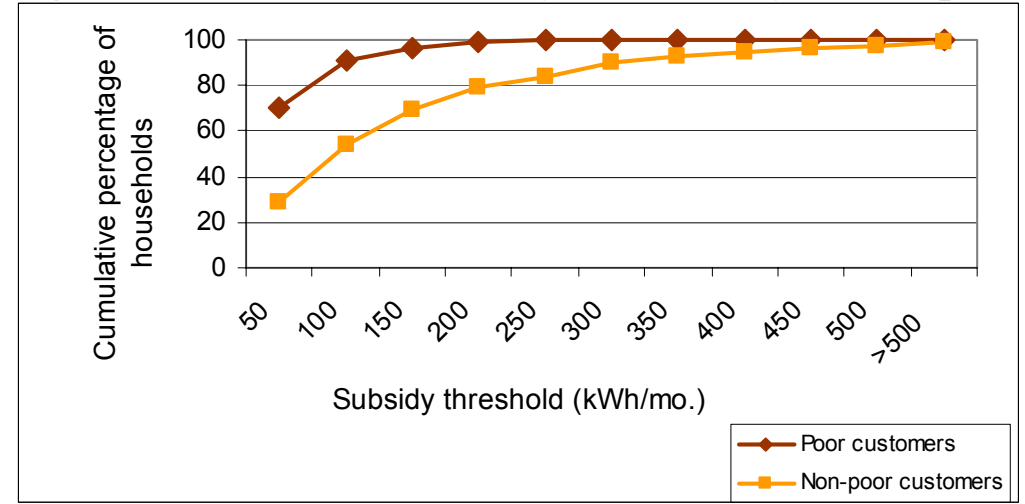

Source: World Bank calculations using the ENCOVI 2000, Instituto Nacional de Estadística - Guatemala

Table 4.1: Comparison of electricity consumption

\begin{tabular}{|c|c|c|}
\hline & Poor & Non-Poor \\
\hline Connection rate & 46 & 76 \\
\hline Average consumption (kWh/mo.) & 48 & 128 \\
\hline Electricity expenditure (\$/mo.) & & \\
\hline - With social tariff & 5.1 & 14.4 \\
\hline - Without social tariff & 7.2 & 21.9 \\
\hline $\begin{array}{l}\text { Electricity expenditure as percentage of monthly budget } \\
\text { - With social tariff }\end{array}$ & 2.7 & 2.6 \\
\hline
\end{tabular}

It is important to question who benefits from the current social tariff policy, and in particular how effective is it at protecting the most vulnerable households. Owing to the high level of the consumption threshold, the social tariff evidently benefits a considerable number of households who live above the poverty line. Indeed, about $65 \%$ of the beneficiaries of both the old and the new schemes are not poor (errors of inclusion ${ }^{24}$ ), and given that their consumption is relatively high they absorb an even larger percentage of the resources devoted to the subsidy (leakage rate ${ }^{25}$ ), $90 \%$ in all (Figure 4.4). The subsidy reaches $100 \%$ of poor households with electricity connections (that is there are no errors of exclusion ${ }^{26}$ ), but only $40 \%$ of poor households enjoy these connections and hence benefit from the subsidy.

Given that poor households consume substantially less electricity than non-poor households, the costeffectiveness of the social tariff could be significantly improved if the consumption threshold was reduced. In order to explore this possibility, a simulation exercise was performed to calculate the errors of inclusion and exclusion, as well as leakage rates, for a series of different consumption thresholds (Figure 4.4). There is an underlying assumption in this exercise that electricity consumption will remain constant despite the changes in the tariff structure by moving the consumption thresholds. The results show that the targeting performance of the subsidy could be significantly improved with an eligibility threshold of $100 \mathrm{kWh}$ per month. Errors of inclusion would fall from $75 \%$ to $65 \%$, and the leakage rate from $90 \%$ to $75 \%$. At the same, time errors of exclusion would rise only $0 \%$ to $8 \%$, while the overall cost of the subsidy would fall to almost a quarter of its current level, from $\$ 48.9$ to $\$ 13.2$ million per year.

\footnotetext{
${ }^{24}$ Errors of inclusion are defined as the percentage of subsidy beneficiaries who are not poor.

${ }^{25}$ The leakage rate refers to the proportion of the total subsidy expenditure that flows to the non-poor.

${ }^{26}$ Errors of exclusion are defined as the percentage of the poor who are not subsidy beneficiaries.
} 


\section{Figure 4.4: Simulation of inclusion and exclusion errors}

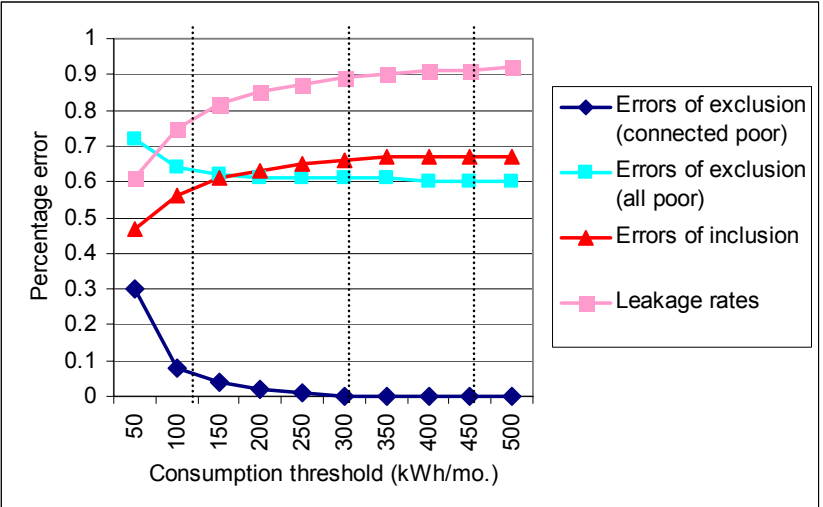

Source: World Bank calculations using the ENCOVI 2000, Instituto Nacional de Estadística - Guatemala

Figure 4.5: Simulation of subsidy cost

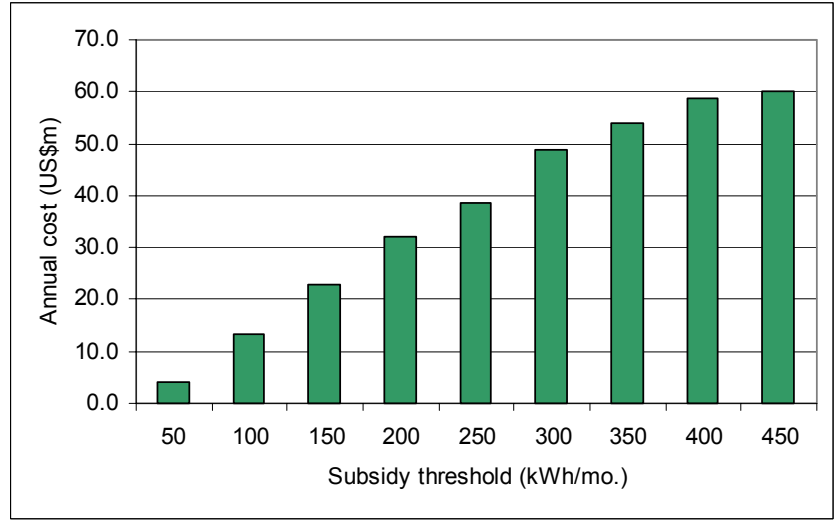

Source: World Bank calculations using the ENCOVI 2000, Instituto Nacional de Estadística - Guatemala

Notwithstanding the considerable policy attention that has gone into subsidies for electricity consumers, the empirical evidence suggests that households that lack access to electricity are in a much worse position in terms of their ability to afford basic energy requirements. The reason is that traditional substitutes for electricity, such as candles and kerosene lamps are extremely inefficient at delivering usable energy (Table 4.2). In particular, electric light bulbs give out 50 times more luminosity per $\mathrm{kWh}$ of raw energy used than do candles, and 100 times more than primitive kerosene wick lamps.

These differences in efficiency need to be taken into account when comparing the prices of these different sources of energy. In the table below, the gross price reports the standard unadjusted market price, while the net price corrects for differences between the efficiency of electricity and alternative energy sources. The results indicate that households without electricity pay 75 to 150 times more per $\mathrm{kWh}$ of light, and 5 to 30 times more per $\mathrm{kWh}$ to power home appliances using dry cell or car batteries. 


\section{Table 4.2: Relative efficiency and luminous efficacy factors used to adjust from gross to net energy consumption}

\begin{tabular}{c|c|c|c}
\hline \multirow{2}{*}{ Fuel } & \multicolumn{2}{c}{ Appliances } \\
& $\begin{array}{c}\text { Relative luminous } \\
\text { efficacy }\end{array}$ & Fuel & Relative efficiency \\
\hline Electricity & 1.00 & Electricity & 1.00 \\
Kerosene & 0.01 & Batteries & 0.90 \\
Candles & 0.02 & Car batteries & 0.90 \\
\hline
\end{tabular}

Source: Foster and Tre, 2000.

\section{Table 4.3: Gross and net unit prices for different fuels (US\$ per $\mathrm{kWh}$ )}

\begin{tabular}{l|c|c|l|c|c}
\hline & Lighting & \multicolumn{3}{c}{ Appliances } \\
& Gross & Net & & Gross & Net \\
\hline Electricity & 0.08 & 0.08 & Electricity & 0.08 & 0.08 \\
Kerosene & 0.05 & 5.87 & Batteries & 0.59 & 0.53 \\
Candles & 0.26 & 13.00 & Car batteries & 2.57 & 2.31 \\
\hline
\end{tabular}

Notes: The unit price is based on the assumption that the batteries are used to power a 16 watt radio.

The unit price is based on the assumption that the batteries are used to power a $16 \mathrm{~W}$ black and white television set.

Source: Foster and Tre, 2000

The much higher implicit energy prices faced by households without electricity translate into very low levels of energy consumption. For example, households in the lowest consumption quintile without access to electricity consume only 1.4 net kilowatt-hours of energy per month on lighting and appliances compared with 40.0 kilowatt-hours per month consumed by households in the lowest consumption quintile who have electricity (Table 4.4). Interestingly, both of these groups of households spend a very similar monthly amount on energy for lighting and appliances; just over Qz.30 (US\$4) per month.

Table 4.4: Energy consumption patterns of those with and without electricity

\begin{tabular}{|c|c|c|c|c|c|c|c|c|c|c|c|c|c|c|c|c|}
\hline & \multirow{2}{*}{\multicolumn{2}{|c|}{ National }} & \multicolumn{4}{|c|}{ By area } & \multicolumn{10}{|c|}{ By quintile } \\
\hline & & & \multicolumn{2}{|c|}{ Urban } & \multicolumn{2}{|c|}{ Rural } & \multicolumn{2}{|c|}{1} & \multicolumn{2}{|c|}{2} & \multicolumn{2}{|c|}{3} & \multicolumn{2}{|c|}{4} & \multicolumn{2}{|c|}{5} \\
\hline $\begin{array}{l}\text { Electricity coverage } \\
\text { rate }(\%)\end{array}$ & \multicolumn{2}{|c|}{73} & \multicolumn{2}{|c|}{94} & \multicolumn{2}{|c|}{57} & \multicolumn{2}{|c|}{40} & \multicolumn{2}{|c|}{64} & \multicolumn{2}{|c|}{77} & \multicolumn{2}{|c|}{89} & \multicolumn{2}{|c|}{95} \\
\hline $\begin{array}{l}\text { Connected to } \\
\text { electricity }\end{array}$ & $\mathrm{Y}$ & $\mathrm{N}$ & $\bar{Y}$ & $\mathrm{~N}$ & $\bar{Y}$ & $\mathrm{~N}$ & $\bar{Y}$ & $\mathrm{~N}$ & $\mathrm{Y}$ & $\mathrm{N}$ & $\mathrm{Y}$ & $\mathrm{N}$ & $\mathrm{Y}$ & $\mathrm{N}$ & $\mathrm{Y}$ & $\mathrm{N}$ \\
\hline $\begin{array}{l}\text { Energy } \\
\text { expenditure(Q/mo.) }\end{array}$ & $90^{* * *}$ & 33 & $119^{* * *}$ & 31 & $52^{* * *}$ & 34 & 37 & 31 & $41^{* * * *}$ & 33 & $60^{* * *}$ & 38 & $82^{* * *}$ & 36 & $174^{* * *}$ & 40 \\
\hline $\begin{array}{l}\text { Percentage of budget } \\
(\%)\end{array}$ & 3 & 3 & 3 & 2 & 3 & 3 & 3 & 3 & 3 & 3 & $3^{*}$ & 3 & $3^{* * *}$ & 2 & $3^{* * *}$ & 2 \\
\hline $\begin{array}{l}\text { Energy consumption } \\
\text { - Gross kwh/mo. }\end{array}$ & $101^{* * *}$ & 21 & $132^{* * *}$ & 58 & $11^{* * *}$ & 23 & $40^{* * *}$ & 22 & $46^{* * *}$ & 23 & $71^{* * *}$ & 23 & $100^{* * *}$ & 15 & $182^{* * *}$ & 15 \\
\hline - Net kwh cons & $101^{* * *}$ & 2.1 & $132^{* * *}$ & .81 & $11^{* * *}$ & 2.2 & $40^{* * *}$ & 1.4 & $46^{* * *}$ & 2.0 & $71^{* * *}$ & 2.6 & $100^{* * *}$ & 2.4 & $182^{* * *}$ & 7.6 \\
\hline $\begin{array}{l}\text { Implicit energy price } \\
\text { - } \mathrm{Q} / \text { gross } \mathrm{kwh} / \mathrm{mo} \text {. } \\
\text { - } \mathrm{Q} / \text { net kwh cons }\end{array}$ & $\begin{array}{l}1.0^{* * *} \\
1.0^{* * *}\end{array}$ & $\begin{array}{l}5.5 \\
85\end{array}$ & $.94^{* * *}$ & $\begin{array}{c}9.1 \\
233\end{array}$ & $\begin{array}{l}1.1^{* * *} \\
1.1^{* * *}\end{array}$ & $\begin{array}{l}5.1 \\
69\end{array}$ & $\begin{array}{l}1.1^{* * *} \\
1.1^{* * *}\end{array}$ & $\begin{array}{l}4.5 \\
69\end{array}$ & $1.1^{* * *}$ & $\begin{array}{l}5.5 \\
84\end{array}$ & $\begin{array}{l}1.0^{* * *} \\
1.0^{* * *}\end{array}$ & $\begin{array}{l}6.1 \\
89\end{array}$ & $\begin{array}{l}.95^{* * *} \\
.95^{* * *}\end{array}$ & $\begin{array}{r}7.9 \\
153\end{array}$ & $\begin{array}{l}.92^{* * *} \\
.92^{* * *}\end{array}$ & $\begin{array}{l}8.9 \\
121\end{array}$ \\
\hline
\end{tabular}

Notes: For those with electricity, energy refers to electricity and for those without electricity, energy refers to electricity substitutes (i.e. candles, kerosene and batteries).

The averages for expenditure and prices excluded households that are connected to the electricity network but did not pay for the service.

If significantly different from those without electricity at: $* 90 \%, * * 95 \%, * * * 99 \%$.

Source: World Bank calculations using the ENCOVI 2000, Instituto Nacional de Estadística - Guatemala 
To give a concrete idea of what such low levels of energy consumption mean in terms of quality of life, it is helpful to think of a subsistence package of energy requirements that can be used to define a 'fuel poverty' line. Based on consultation with local energy experts about the energy needs of low income households, this subsistence package provides enough energy to run two 60 watt light bulbs and one 16 watt radio for four hours each day, and incorporates a cooking requirement of ten kilograms of fuel wood each day. The survey indicates that $92 \%$ of households without access to electricity have energy consumption levels that fall below the 'fuel poverty' line, compared to only $35 \%$ of households with access to electricity (Table 4.5). It is estimated that if these households had access to electricity they would be able to substantially increase their energy consumption, so that the fuel poverty rate would fall from $92 \%$ to between $37 \%$ and $73 \%$, depending on what assumption is made about the price elasticity of demand.

Table 4.5: Fuel poverty estimates with and without access to electricity

\begin{tabular}{|c|c|c|c|c|c|}
\hline & \multirow{3}{*}{$\begin{array}{l}\text { Households } \\
\text { with access } \\
\text { to electricity }\end{array}$} & \multicolumn{4}{|c|}{ Households without access to electricity } \\
\hline & & \multirow[t]{2}{*}{$\begin{array}{c}\text { Current } \\
\text { situation }\end{array}$} & \multicolumn{3}{|c|}{$\begin{array}{l}\text { After gaining access, for different price } \\
\text { elasticities of demand for energy }\end{array}$} \\
\hline & & & $\varepsilon=-0.5$ & $\varepsilon=-1$ & $\varepsilon=-1.5$ \\
\hline $\begin{array}{l}\text { Price per effective kwh }(\mathrm{Q}) \\
\text { Net consumption (kwh/month) }\end{array}$ & $\begin{array}{c}1.7 \\
67.5\end{array}$ & $\begin{array}{c}39.3 \\
.98\end{array}$ & $\begin{array}{c}1.8 \\
16.2\end{array}$ & $\begin{array}{c}1.8 \\
21.6\end{array}$ & $\begin{array}{c}1.8 \\
32.4\end{array}$ \\
\hline $\begin{array}{l}\text { Fuel poverty } \\
\text { Headcount } \\
\text { Poverty gap } \\
\text { Squared poverty gap }\end{array}$ & $\begin{array}{l}.27 \\
.12 \\
.08\end{array}$ & $\begin{array}{c}1.00 \\
.94 \\
.89\end{array}$ & $\begin{array}{l}.68 \\
.34 \\
.21\end{array}$ & $\begin{array}{l}.55 \\
.24 \\
.14\end{array}$ & $\begin{array}{l}.33 \\
.14 \\
.08\end{array}$ \\
\hline
\end{tabular}

Note: Refers only to energy used for lighting and appliances, based on a poverty line of $200 \mathrm{kwh} / \mathrm{year}$ Source: World Bank calculations using the ENCOVI 2000, Instituto Nacional de Estadística - Guatemala

\subsection{Water}

The typical tariff structure for water in Guatemala comprises a flat payment up to a relatively high consumption threshold, and a linear unit charge for consumption above this level. This kind of tariff structure has the disadvantage that it does not provide any incentive for households to control consumption below this threshold level.

A recent survey of water tariffs found that in the larger cities - Guatemala and Quetzaltenango- the flat rate charge of $\$ 1$ to $\$ 2$ per month entitled households to consume between 15 and 25 cubic meters per month, while further consumption was charged at a rising rate of between $\$ 0.10$ and $\$ 0.30$ per cubic meter (Figure 4.6) (ESA Consultores, 2001). The same survey found that water charges in the smaller towns of the interior were substantially lower, with a flat charge of around $\$ 0.50$ per month entitling the household to around 30 to 40 cubic meters per month, and subsequent consumption being charged at less than $\$ 0.10$ per cubic meter (Figure 4.6). The implication is that for a typical monthly consumption of 20 cubic meters, households in the larger cities would be paying an implicit tariff of less than $\$ 0.10$ per cubic meter, while households in the smaller cities would be paying less than $\$ 0.05$ per cubic meter. 
(a) Large cities

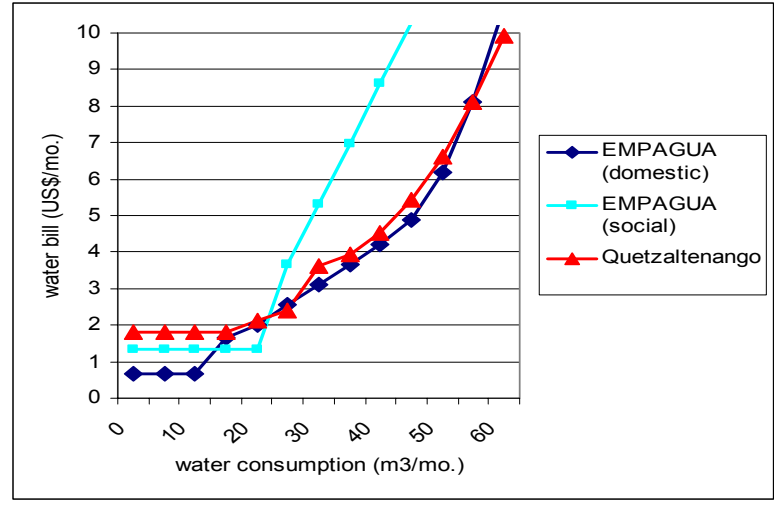

Figure 4.6: Typical structure of water bills

(b) Small towns

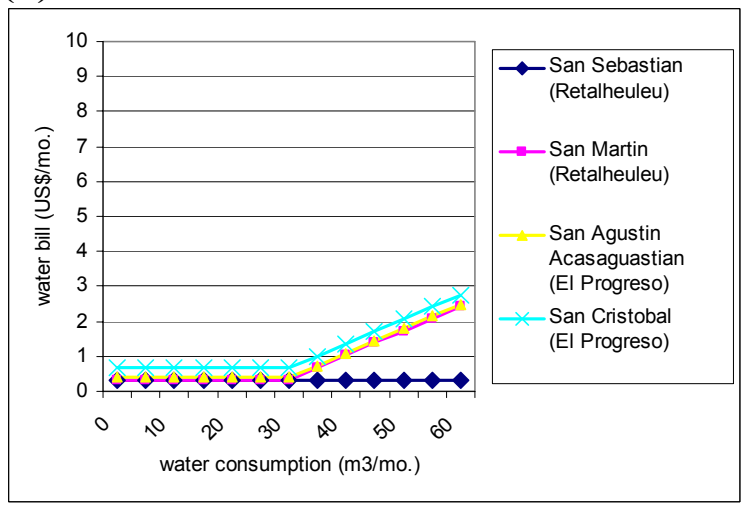

Source: IADB

Not only are water tariffs very low, but survey evidence suggests that revenue collection rates are also extremely low. On average, as many as 30\% of those with piped water reported that they did not pay for the service during the last month, compared with only $8 \%$ for the electricity service in spite of the fact that average monthly electricity bills are almost 10 times as high as average water bills (US\$12.97 versus US\$1.48). Among the poorest, non-payment rate rises to $46 \%$.

As a result, water utility revenues are extremely low, both with respect to the likely cost of providing water and sanitation services, and with respect to the likely willingness and ability to pay of the population.

Although there is no available information about the cost of potable water in Guatemala, international benchmarks would suggest a full cost of around $\$ 0.30$ to $\$ 0.40$ per cubic meter, exclusive of sewerage. This suggests that at current tariff levels, water utilities are unlikely to be covering their operating costs, let alone their capital costs.

Table 4.6: Comparison of expenditures on piped and bottled water

\begin{tabular}{|c|c|c|c|c|c|c|c|c|}
\hline & \multirow[t]{2}{*}{ National } & \multicolumn{2}{|c|}{ By area } & \multicolumn{5}{|c|}{ By consumption quintile } \\
\hline & & Urban & Rural & 1 & 2 & 3 & 4 & 5 \\
\hline$\%$ of households that bought bottled water ${ }^{1}$ & .17 & .33 & .04 & .02 & .03 & .08 & .23 & .47 \\
\hline Among those who bought bottled water & & & & & & & & \\
\hline Quetzales spent on piped water & 16 & 24 & 5 & 1 & 5 & 7 & 12 & 34 \\
\hline Quetzales spent on bottled water & 47 & 50 & 30 & 10 & 30 & 30 & 39 & 56 \\
\hline Expenditure on piped water as $\%$ of consumption & .004 & .005 & .002 & .001 & .003 & .003 & .004 & .006 \\
\hline Expenditure on bottled water as $\%$ of consumption & .01 & .01 & .01 & .01 & .01 & .01 & .01 & .01 \\
\hline
\end{tabular}

In terms of willingness to pay, the WHO has traditionally recommended an affordability threshold of 5\% of income for water and sanitation services, about 10 times as high as what households in Guatemala currently spend. Recent research in Central America-involving willingness to pay surveys in Nicaragua, Panama, and El Salvador - has provided empirical confirmation of the WHO threshold (Walker et al., 2000). Further confirmation of willingness to pay for water in Guatemala comes from expenditure on bottled water. The ENCOVI survey shows that $20 \%$ of households purchase bottled 
water at a price of $\$ 0.50$ per liter (equivalent to $\$ 500$ per cubic meter). Moreover, households who use both piped and bottled water, spend three times more on bottled water than on piped water.

Table 4.7: Water treatment practices

\begin{tabular}{|c|c|c|c|c|c|c|c|c|}
\hline & \multirow[t]{2}{*}{ National } & \multicolumn{2}{|c|}{ By area } & \multicolumn{5}{|c|}{ By consumption quintile } \\
\hline & & Urban & Rural & 1 & 2 & 3 & 4 & 5 \\
\hline Among those with water in dwelling & 13 & 22 & 02 & 002 & 01 & 04 & 13 & 35 \\
\hline Buys bottled water and also treats & .08 & .13 & .03 & .02 & .03 & .05 & .12 & .15 \\
\hline Boils water & .38 & .29 & .50 & .55 & .51 & .47 & .32 & .20 \\
\hline Filters water & .02 & .02 & .01 & .001 & .004 & .003 & .01 & .04 \\
\hline Puts chlorine & .12 & .12 & .12 & .07 & .10 & .16 & .18 & .09 \\
\hline Other strategy & .01 & .01 & .003 & .001 & .01 & .003 & .01 & .01 \\
\hline No treatment & .26 & .20 & .32 & .36 & .34 & .27 & .24 & .15 \\
\hline Among those without water in dwell & & & & & & & & \\
\hline Buys bottled water only & .03 & .11 & .01 & 0 & .02 & .02 & .11 & .07 \\
\hline Buys bottled water and also treats & .02 & .05 & .02 & .005 & .02 & .03 & .04 & .09 \\
\hline Boils water & .42 & .43 & .41 & .51 & .39 & .42 & .32 & .16 \\
\hline Filters water & .002 & .001 & .002 & .0003 & .0004 & .005 & .002 & .003 \\
\hline Puts chlorine & .17 & .15 & .17 & .09 & .17 & .23 & .19 & .37 \\
\hline Other strategy & .01 & .0005 & .01 & .002 & .0003 & .001 & .03 & .05 \\
\hline No treatment & .35 & .25 & .37 & .40 & .40 & .30 & .31 & .26 \\
\hline
\end{tabular}

Source: World Bank calculations using the ENCOVI 2000, Instituto Nacional de Estadística - Guatemala

The shortage of resources going into the sector probably goes some way towards explaining the relatively low quality of service provided. Households surveyed in the ENCOVI received water on average only 17 hours per day and faced 3.6 days each month without water. The fact that as many as $74 \%$ of households with piped water, either buy bottled water or perform some kind of self-treatment, suggests that they are not confident about the potability of public water supply (Table 4.7). Boiling is the most popular form of self-treatment, particularly among low-income households and in rural areas. While higher income urban households are more likely to rely on bottled water. It is very striking that the prevalence of water boiling is about the same for households who have piped water as for households without the service, around $40 \%$ in both cases.

\section{Benefits of Access to Modern Utilities}

It is often argued that access to modern utility services brings benefits to households in terms of improved productivity and health. While these arguments are intuitively persuasive, there is relatively limited rigorous empirical evidence to document the link and quantify the magnitude of the associated effects. Therefore, this section uses the ENCOVI survey data to try and shed some light on the nature of these relationships.

\subsection{Productivity benefits}

\section{Use of household time endowment}

It is anecdotally well-known that the collection of fuel wood and water for household use, particularly in rural areas, can be very time consuming and it is often suggested that these activities come at the cost of more productive pursuits, such as paid employment or education of children (Table 5.1). 


\section{Table 5.1: Anecdotal evidence on time use from qualitative poverty study}

'A los niños los ponen a trabajar, a traer leña, a acarrear agua.'

School Teacher, Ladino Community, Qualitative Poverty Study.

In the ENCOVI, households who collect water on a regular basis report that on average they travel around nine minutes to reach their nearest water source (Table 5.2). The equivalent distance for fuel wood collection was a 50 minute walk in urban areas and a 70 minute in rural areas. The average number of persons per household involved in such a trip is around 1.50 in urban areas and 1.85 in rural areas. Moreover, the survey demonstrates clear gender specialization in collection activities, with men and boys accounting for $65 \%$ of the labor devoted to the collection of fuel wood, and women and girls accounting for $74 \%$ of the labor devoted to the collection of water (Figure 5.1).

Table 5.2: Distance to source of wood and water

(Among those who collect water and buy or collect wood)

\begin{tabular}{r|c|c|c|c|c|c|c|c}
\hline & National & \multicolumn{2}{|c|}{ By area } & \multicolumn{5}{c}{ By consumption quintile } \\
\hline & & Urban & Rural & 1 & 2 & 3 & 4 & 5 \\
\cline { 3 - 9 } Water collection & & & & & & & & \\
Minutes & 12.5 & 13.2 & 12.3 & 14.5 & 12.8 & 10.6 & 12.6 & 7.0 \\
Meters & 242 & 111 & 267 & 351 & 216 & 222 & 136 & 72 \\
Minutes & 63.4 & 51.0 & 67.2 & 66.9 & 67.2 & 63.3 & 54.8 & 47.9 \\
Meters & 1,336 & 1,032 & 1,448 & 1,611 & 1,511 & 1,236 & 961 & 917 \\
\hline
\end{tabular}

Source: World Bank calculations using the ENCOVI 2000, Instituto Nacional de Estadística - Guatemala

Figure 5.1: Intra-Household Allocation of Fuel Wood and Water Collection Tasks (individuals who collected wood and water on the day before the survey)

(a) Fuel wood

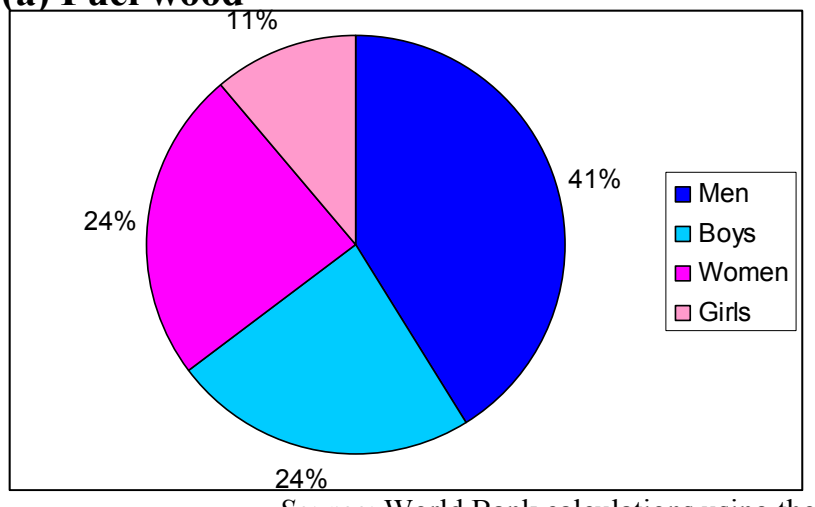

(b) Water

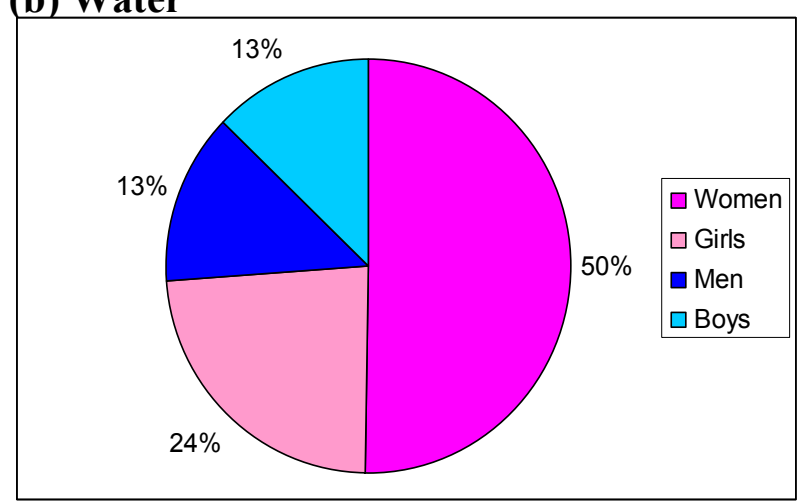

Source: World Bank calculations using the ENCOVI 2000, Instituto Nacional de Estadística - Guatemala 


\section{Table 5.3: Time devoted to collection of fuel wood and water according to whether or not the household has access to modern water and energy services}

\begin{tabular}{|c|c|c|c|c|c|c|}
\hline \multirow[b]{3}{*}{ Access to modern services } & \multirow{2}{*}{\multicolumn{2}{|c|}{ National }} & \multicolumn{4}{|c|}{ By area } \\
\hline & & & \multicolumn{2}{|c|}{ Urban } & \multicolumn{2}{|c|}{ Rural } \\
\hline & $\bar{Y}$ & $\mathrm{~N}$ & $\mathrm{Y}$ & $\mathrm{N}$ & $\mathrm{Y}$ & $\mathrm{N}$ \\
\hline Proportion of households who collected yesterday & & & & & & \\
\hline - $\quad$ Fuel wood & .04 & .18 & .01 & .11 & .08 & .19 \\
\hline - Water & .03 & .33 & .02 & .22 & .05 & .35 \\
\hline No. of minutes spent collecting yesterday & & & & & & \\
\hline - $\quad$ Fuel wood & 102 & $162^{* * *}$ & 77 & $173^{* * *}$ & 121 & $161^{* * *}$ \\
\hline - Water & 63 & $96^{* * *}$ & 62 & $75^{* * *}$ & 64 & $99^{* * *}$ \\
\hline Expected no. of minutes per week spent collecting & 29 & $204^{* * *}$ & 5 & $133^{* * *}$ & 68 & $214^{* * *}$ \\
\hline - Water & 13 & $221^{* * *}$ & 9 & $116^{* * *}$ & 22 & $243^{* * *}$ \\
\hline
\end{tabular}

\begin{tabular}{|c|c|c|c|c|c|c|c|c|c|c|}
\hline \multirow[b]{3}{*}{ Access to modern services } & \multicolumn{10}{|c|}{ By quintile } \\
\hline & \multicolumn{2}{|c|}{1} & \multicolumn{2}{|c|}{2} & \multicolumn{2}{|r|}{3} & \multicolumn{2}{|c|}{4} & \multicolumn{2}{|c|}{5} \\
\hline & $\mathrm{Y}$ & $\mathrm{N}$ & $\mathrm{Y}$ & $\mathrm{N}$ & $\mathrm{Y}$ & $\mathrm{N}$ & $\mathrm{Y}$ & $\mathrm{N}$ & $\mathrm{Y}$ & $\mathrm{N}$ \\
\hline $\begin{array}{l}\text { Proportion of households who collected yesterday } \\
\text { - Fuel wood }\end{array}$ & .16 & .19 & .06 & .18 & .09 & .18 & 04 & 14 & 01 & 10 \\
\hline - Water & .03 & .35 & .04 & .37 & .06 & .35 & .02 & .31 & .01 & .24 \\
\hline No. of minutes spent collecting yesterday & & & & & & & & & & \\
\hline - $\quad$ Fuel wood & na & 202 & 154 & 165 & 94 & 99 & 72 & 107 & na & 86 \\
\hline - Water & 82 & $127^{*}$ & 65 & $93^{* *}$ & 70 & 76 & 50 & 57 & 21 & 84 \\
\hline $\begin{array}{l}\text { Expected no. of minutes per week spent collecting } \\
\text { - Fuel wood }\end{array}$ & na & 268 & 208 & $65^{* * *}$ & 59 & $124^{* * *}$ & 20 & $105^{* * *}$ & na & 62 \\
\hline - Water & 17 & $311^{* * *}$ & 18 & $242^{* * *}$ & 29 & $185^{* * *}$ & 7 & $124^{* * *}$ & 1 & $141^{* * *}$ \\
\hline
\end{tabular}

na: Less than 30 observations were available.

Notes: A modern water service is defined as having piped water in the dwelling or yard. A modern energy service is defined as having access to propane. Percentage of households with and without service are significantly different at: ${ }^{* *} 99 \%,{ }^{* *} 95 \%$ and ${ }^{*} 90 \%$. Expected minutes $=7 *$ proportion who collected yesterday * minutes spent collecting. Source: World Bank calculations using the ENCOVI 2000, Instituto Nacional de Estadística - Guatemala

Clearly, one of the potential benefits of providing households with access to piped water and modern energy sources, such as propane, is that they can save the time that would otherwise be devoted to collection activities. Using the ENCOVI data, it is possible to estimate the number of minutes per week that households spend on average collecting fuel wood and water, and to compare this between households that have access to modern alternatives and those that do not (Table 5.9). In urban areas, households without access to modern utilities spend on average two man-hours per week on each of the two collection activities, while those who have access spend less than ten minutes per week on each. In rural areas, households with access spend closer to four man-hours per week on each activity. However, even those with services spend a significant amount of time collecting fuel wood and water. This may be a reflection of the lower reliability of these services in rural areas. Consequently, the time saving for rural households who gain access to modern services is 2.5 hours per week for fuel wood and 3.5 hours per week for water.

Although it is difficult to place an economic value on these time savings, an approximate indication can be obtained from the average hourly earnings of rural workers in the agricultural sector, which are of the order of Q.3-4 (US\$0.50) (Vakis, 2001). This would suggest that the value of weekly time savings associated with piped water could be around Q.12 (US\$1.75), compared with a typical weekly piped water bill of Q.3 nationwide, or less than Q.1 in rural areas. The implication is that households who are not cash constrained would find it attractive to switch to a piped service. Although, the benefits are 
exaggerated due to artificially depressed current water tariffs, the difference is significantly large that piped water would continue to remain attractive, even if water tariffs increased substantially. In the case of propane, the comparison is not so favorable, with a weekly value of time savings of around Q.9 (US\$1.25), compared with a typical weekly energy bill of around Q.18.

Table 5.4 Time allocation and wood collection

(Number of minutes spent yesterday in each activity among those who spent time on them)

\begin{tabular}{|c|c|c|c|c|c|c|c|c|}
\hline & \multicolumn{4}{|c|}{ Urban } & \multicolumn{4}{|c|}{ Rural } \\
\hline & \multicolumn{2}{|c|}{ Female } & \multicolumn{2}{|c|}{ Male } & \multicolumn{2}{|c|}{ Female } & \multicolumn{2}{|c|}{ Male } \\
\hline & $7-15$ & $>15$ & $7-15$ & $>15$ & $7-15$ & $>15$ & $7-15$ & $>15$ \\
\hline Paid work & & & & & & & & \\
\hline Did not collect & 33 & 167 & 34 & 360 & 19 & 85 & 55 & 342 \\
\hline Collected & 0 & 82 & 50 & 275 & 9 & 47 & 34 & 263 \\
\hline Difference & $* * *$ & **** & & & * & $* * *$ & *** & \\
\hline \multicolumn{9}{|l|}{ Unpaid work } \\
\hline Did not collect & 39 & 57 & 49 & 81 & 75 & 74 & 172 & 159 \\
\hline Collected & 48 & 43 & 103 & 164 & 75 & 82 & 165 & 216 \\
\hline & & & & & & & & \\
\hline \multicolumn{9}{|l|}{ Study } \\
\hline Did not collect & 312 & 314 & 296 & 299 & 302 & 282 & 311 & 296 \\
\hline Collected & 382 & 368 & 302 & 178 & 285 & 313 & 299 & 243 \\
\hline Difference & & & & & & & & \\
\hline \multicolumn{9}{|l|}{ Housework } \\
\hline Did not collect & 136 & 373 & 44 & 58 & 194 & 448 & 34 & 33 \\
\hline Collected & 263 & 416 & 48 & 73 & 251 & 466 & 62 & 43 \\
\hline Difference & & & & & & & & \\
\hline \multicolumn{9}{|l|}{ Errands/shopping } \\
\hline Did not collect & 10 & 23 & 9 & 12 & 7 & 15 & 6 & 10 \\
\hline Collected & 34 & 29 & 6 & 14 & 10 & 20 & 9 & 11 \\
\hline Difference & ** & & & & & & & \\
\hline \multicolumn{9}{|l|}{ Leisure and other } \\
\hline Did not collect & 913 & 750 & 951 & 778 & 916 & 763 & 945 & 799 \\
\hline Collected & 781 & 658 & 940 & 777 & 846 & 709 & 903 & 776 \\
\hline Difference & & & & & & & & \\
\hline
\end{tabular}

Notes: Means of those who collected and did not collect wood are significantly different at: $* * * 99 \%, * * 95 \%$ and $* 90 \%$.

Minutes spent collecting wood among those who did it. The symbols describe cells that are significantly different from the one to the right at: ${ }^{\wedge} 99 \%,{ }^{\wedge} 95 \%,{ }^{\wedge} 90 \%$.

Source: World Bank calculations using the ENCOVI 2000, Instituto Nacional de Estadística - Guatemala

Those devoting such significant amounts of time to wood and water collection activities must presumably do so at the expense of other activities. It is therefore interesting to explore which types of activities households who engage in wood and water collection (Tables 5.4 and 5.5) curtail. Paid work and leisure (including sleep) seem to be the activities that are cut back the most in order to accommodate wood and water collection. Interestingly, the amount of time devoted to study by children who do and do not engage in these activities is not significantly different in most cases. 
Table 5.5 Time allocation and water collection

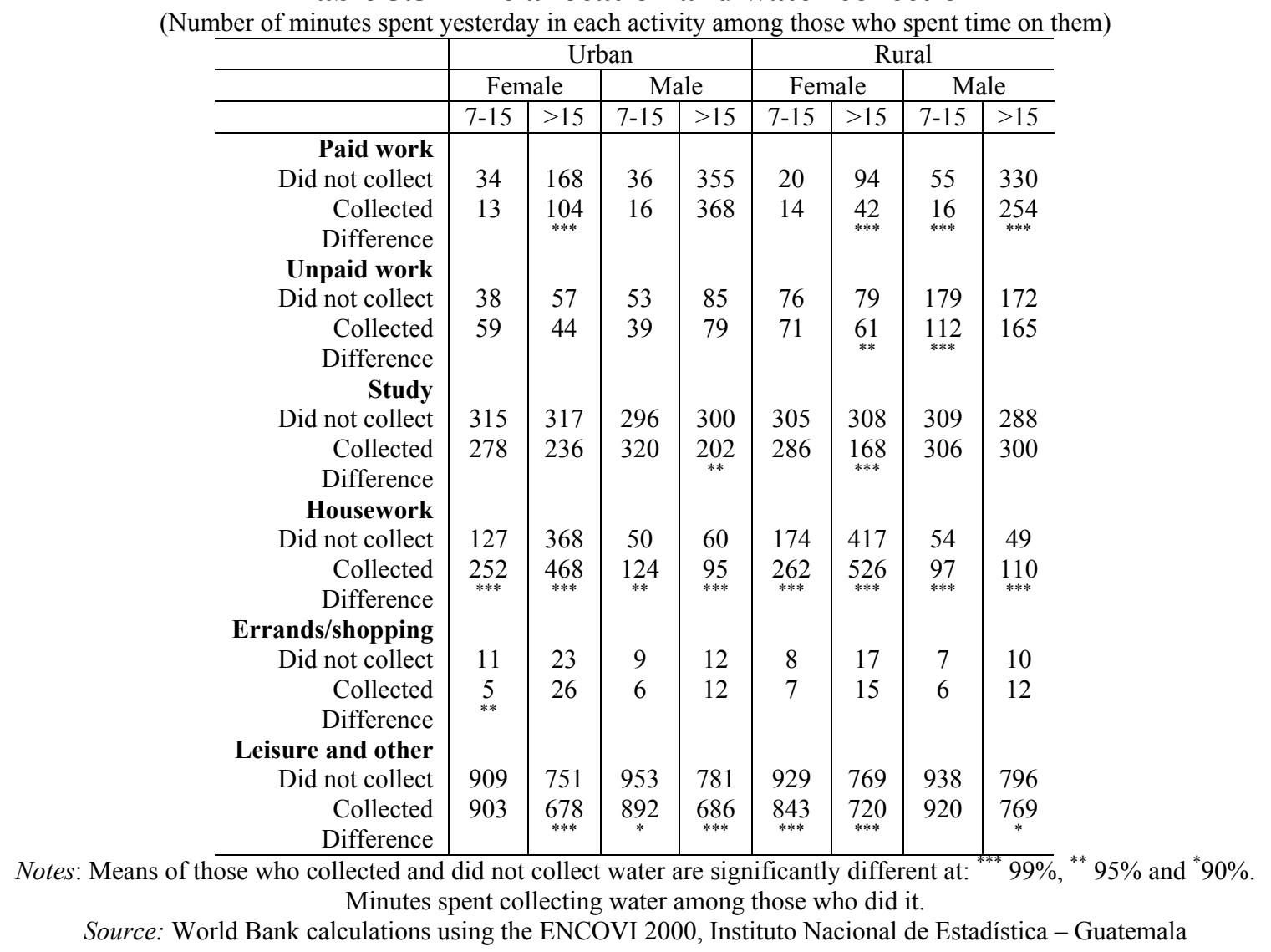

\section{Micro-enterprise productivity}

Modern utilities, in particular electricity and telecommunications, have the potential to improve the productivity of household based micro-enterprises. The electrification of household enterprises lengthens the potential working day, and permits the substitution of manual labor with more efficient power-assisted tools. Telecommunications improve links between enterprises and downstream buyers, as well as upstream suppliers, thereby helping entrepreneurs to expand sales and reduce supply costs.

While these arguments are convincing at an anecdotal level, there is limited rigorous empirical evidence to back them up. Using the data provided by the ENCOVI, this section explores firstly, whether households in areas where modern utilities are available are more likely to have household enterprises, and secondly, whether household enterprises that have access to modern utilities are significantly more profitable than those enterprises that do not. An important caveat is that all of the analysis in this section refers exclusively to households that own a micro-enterprise that operates in the dwelling.

As a preliminary step, the proportion of households with micro-enterprises is tabulated against the various indices of access to modern utilities developed above (Table 5.6). The results show that the probability of having a micro-enterprise is significantly higher among households with coverage of 
modern utilities. However, within communities that have access to modern utilities, households that take-up a connection are no more likely to be entrepreneurs than those that do not (except in the case of fixed telephones).

Table 5.6: Cross-tabulation of household enterprise against access to modern utilities

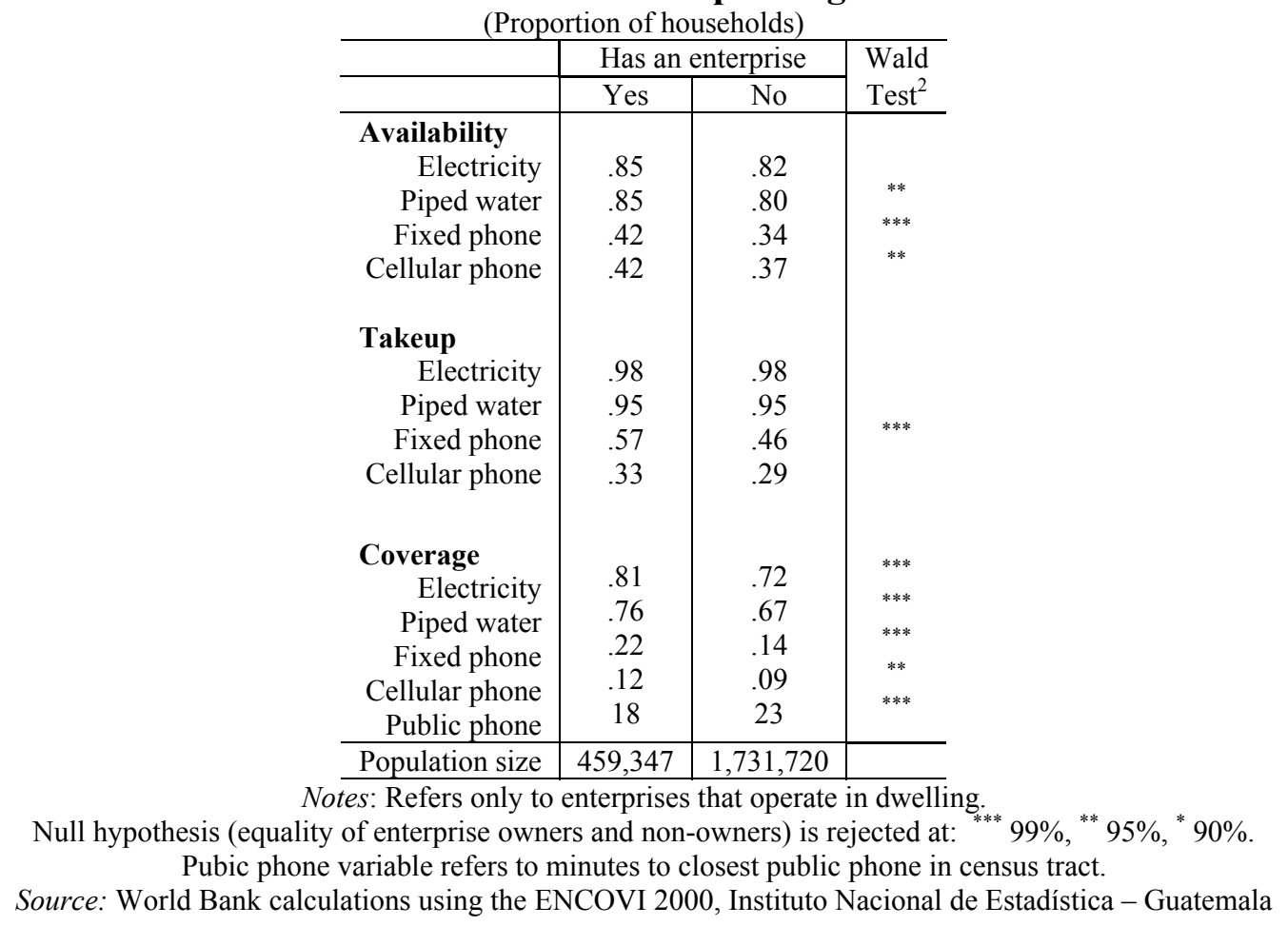

However, it is not possible to draw any inferences from cross-tabulations of this kind, because they do not control for many other factors that influence the disposition to form a business. In order to address this issue, a probit model is estimated that looks at the correlation between a variety of factors including characteristics of the households and the head of household, availability of modern utilities and geographical variables. Separate models are estimated for urban and rural enterprises (Table 5.7).

An important methodological issue that arises is the potential endogeneity of access to modern utilities. The model is estimated on the statistical assumption that access to modern utilities affects the probability of forming a micro-enterprise, but not vice versa. However, it could equally be argued that the presence of a micro-enterprise influences the choice of whether or not to connect to modern utilities. In order to avoid the resulting bias in the statistical estimates, it is necessary to find an instrumental variable that is related to the variable of interest but which has a greater claim of exogeneity. In this case, the community availability of the basic service is used as an instrument; that is to say, that instead of looking at whether or not the household has access to the service, the model looks at whether or not the household lives in a neighborhood ${ }^{27}$ that has access to the service. It can be argued that local availability is somehow more likely to be exogenous to enterprise formation than household connection.

\footnotetext{
${ }^{27}$ As explained earlier, we use the word community in this context to describe clusters of contiguous households on which the survey design was based.
} 
Table 5.7: Results of probit model for probability of having a micro-enterprise

\begin{tabular}{|c|c|c|c|}
\hline \multicolumn{4}{|c|}{ (Coefficients are marginal effects) } \\
\hline & $\begin{array}{c}\text { Everyone } \\
\partial \mathrm{F} / \partial \mathrm{x}\end{array}$ & $\begin{array}{l}\text { Urban } \\
\partial \mathrm{F} / \partial \mathrm{x}\end{array}$ & $\begin{array}{l}\text { Rural } \\
\partial \mathrm{F} / \partial \mathrm{x}\end{array}$ \\
\hline \multicolumn{4}{|l|}{ Household head characteristics } \\
\hline Male & -.009 & .038 & $-.073^{* *}$ \\
\hline Age & $.002^{* * *}$ & $.002^{* *}$ & $.001^{*}$ \\
\hline Years of school & .003 & .003 & .005 \\
\hline Speaks Spanish & .039 & $.135^{* * *}$ & .024 \\
\hline Indigenous & $.077^{* * *}$ & .059 & $.077^{* *}$ \\
\hline \multicolumn{4}{|l|}{ Household characteristics } \\
\hline Number of adults & $.021^{* * *}$ & $.017^{* *}$ & $.022^{* * *}$ \\
\hline Urban area & .008 & & \\
\hline Population in locality & -.0001 & -.0002 & .002 \\
\hline \multicolumn{4}{|l|}{ Availability of utilities } \\
\hline Electricity & .008 & .028 & -.011 \\
\hline Water & .028 & .067 & -.003 \\
\hline Fixed phone & .036 & .035 & .031 \\
\hline Cellular phone & .001 & -.017 & .011 \\
\hline Minutes to public phone & -.0003 & $-.0009^{* *}$ & -.0001 \\
\hline \multirow{3}{*}{$\begin{array}{l}\text { Population size } \\
\text { F }\end{array}$} & $1,553,028$ & 735,373 & 817,655 \\
\hline & $(19,869)$ & $(18,870)$ & $(18,870)$ \\
\hline & 4.76 & 4.38 & 3.92 \\
\hline
\end{tabular}

The results report the marginal effects from the probit model, that is to say how much a $1 \%$ change on each continuous variable would affect the probability that a household enterprise is formed (for binary variables, we observe the effect of the change from 0 to 1). Enterprises are significantly more likely to be formed in larger households, with older heads of household. There is evidence of a small but significant effect from being located relatively close to a public telephone, but only in urban areas.

In the discussion that follows, attention is limited to those households that have a micro-enterprise, and turns to the question of how their profitability is affected by access to utilities. While the estimations so far have included expansion factors to have a sample that is representative at the national level, in the exercise that follows, attention is limited to the sample of households that have a micro-enterprise that operates in the dwelling and uses no expansion factors.

The cross-tabulation of net income per worker-hour indicates that households covered by modern utilities have significantly more profitable enterprises. The differences in profitability are very substantial: almost double for water, more than double for electricity, more than three times as high for fixed telephones and almost four times as high for cellular telephones. Moreover, within communities that have access to services, enterprises that take-up connections to electricity and telecommunications services are significantly and substantially more profitable than those that do not. 


\section{Table 5.8: Cross-tabulation of enterprise profitability against access to modern utilities}

(Net income of owner in Quetzales per worker-hour)

\begin{tabular}{c|c|c|c}
\hline & \multicolumn{2}{|c|}{ Basic service } & \multirow{2}{*}{ Wald } \\
\cline { 1 - 2 } & Yes & No & Test \\
\hline Coverage & & & \multirow{2}{*}{$* * *$} \\
Electricity & 8.0 & 3.4 & ${ }^{* *}$ \\
Piped water & 7.9 & 4.7 & ${ }^{* * *}$ \\
Fixed phone & 15.9 & 4.6 & ${ }^{* * *}$ \\
Cellular phone & 20.2 & 5.2 & \\
Public phone & 7.5 & 7.0 & \\
& & & \\
Takeup & & & \\
Electricity & 7.8 & 3.2 & \\
Piped water & 7.9 & 4.2 & \multirow{2}{*}{$* *$} \\
Fixed phone & 15.9 & 6.2 & $* * *$ \\
Cellular phone & 20.2 & 6.8 & \\
& & & \\
Availability & & & $* * *$ \\
Electricity & 7.7 & 3.5 & $* * *$ \\
Piped water & 7.4 & 5.0 & $* * *$ \\
Fixed phone & 11.2 & 4.0 & $* * *$ \\
Cellular phone & 10.6 & 4.4 & \\
\hline Population size & \multicolumn{2}{|c|}{459,347} & \\
\hline
\end{tabular}

Notes: Refers only to enterprises that operate in dwelling. Null hypothesis (equality of profits between enterprises covered and not) is rejected at: ${ }^{* * *} 90 \%,{ }^{* *} 95 \%,{ }^{*} 90 \%$. Public phone variable refers to availability of public phone in census tract.

Source: World Bank calculations using the ENCOVI 2000, Instituto Nacional de Estadística - Guatemala

However, as before, it is necessary to control for other factors affecting enterprise profitability before reaching conclusions about the role of basic infrastructure services. In addition to the variables used above, a set of variables describing the characteristics of the business is introduced. These include measures of capital and labor input, sector of activity, source of finance, and type of premises.

Once again, there are potential endogeneity problems with access variables, since it seems likely that not only does access improve profitability, but also profitability may increase the likelihood of access. This problem is addressed by instrumenting each of the utility access variables, in a series of first-stage regressions using the community availability of the service as an instrument. As noted above, it can be argued that local availability is more likely to be exogenous than household availability. It could however be argued that local availability is correlated with unobserved characteristics of the local market. In order to control for this potential effect, a series of municipality specific dummies (or fixed effects) were included in the regressions.

As might be expected, the results indicate that enterprise profitability is significantly related to the magnitude of labor and capital inputs and the type of financing facilities that are available. Utility coverage variables do not prove to be statistically significant in urban areas, perhaps because coverage of services is close to universal, and hence there is little variation from which to estimate the coefficient. In rural areas-on the other hand-coverage of electricity, water and cellular telephones are all statistically significant with sizable coefficients. Moreover, the overall explanatory power of this model is much higher than the urban one, with an R-squared coefficient of 55\% versus $15 \%$. 
Table 5.9: Results for regression model of profitability of the household micro-enterprise

\begin{tabular}{|c|c|c|}
\hline & Urban & Rural \\
\hline \multicolumn{3}{|l|}{ Household head characteristics } \\
\hline Male & $.437^{*}$ & .026 \\
\hline Age & -.011 & $-.011^{* *}$ \\
\hline Years of school & -.035 & .018 \\
\hline Speaks Spanish & .634 & .037 \\
\hline Indigenous & -.139 & .247 \\
\hline \multicolumn{3}{|l|}{ Household characteristics } \\
\hline Number of adults & -.101 & .063 \\
\hline Population in locality & -.003 & $.0001^{*}$ \\
\hline \multicolumn{3}{|l|}{ Coverage of utilities } \\
\hline Electricity & -2.14 & $.503^{* *}$ \\
\hline Water & .931 & $1.0^{* * *}$ \\
\hline Fixed phone & 1.73 & -1.04 \\
\hline Cellular phone & 2.36 & $2.7^{* *}$ \\
\hline Minutes to closest public phone & .0008 & -.001 \\
\hline \multicolumn{3}{|l|}{ Business characteristics } \\
\hline Capital (Q) & $6 \times 10^{-8}$ & $1 \times 10^{-5^{*}}$ \\
\hline Labor (man-hours) & $.001^{* * *}$ & $.001^{* * *}$ \\
\hline Age of business (years) & -.001 & -.004 \\
\hline Months worked last year (\#) & $.092^{* * *}$ & $.105^{* * *}$ \\
\hline \multicolumn{3}{|l|}{ Economic activity } \\
\hline Manufacture & .283 & -.144 \\
\hline Services & -.124 & .281 \\
\hline \multicolumn{3}{|l|}{ Provider } \\
\hline Large firm & .254 & .080 \\
\hline Small firm & .030 & .013 \\
\hline \multicolumn{3}{|l|}{ Source of finance } \\
\hline Bank / cooperative / NGO & $.898^{*}$ & .460 \\
\hline Family / friends & $.720^{*}$ & $.836^{* *}$ \\
\hline Providers & -.113 & $1.45^{* *}$ \\
\hline Savings / assets / inheritance & $1.02^{* *}$ & $.660^{*}$ \\
\hline \multicolumn{3}{|l|}{ Type of dwelling } \\
\hline House & .507 & $-.458^{*}$ \\
\hline Constant & 3.66 & $5.13^{* * *}$ \\
\hline Observations & 634 & 478 \\
\hline Pseudo R-squared & .1537 & .5553 \\
\hline Chi 2 & 332.59 & 671.08 \\
\hline
\end{tabular}

Notes: Results reported are those of second-stage regression. Coverage of basic services for electricity, water, fixed and cellular phone were instrumented using availability of these services in census tract as instrument. Estimations include a municipality-level fixed effect.

Significant at: ${ }^{* * *} 90 \%,{ }^{* *} 95 \%,{ }^{*} 90 \%$.

Refers only to enterprises that operate in dwelling.

Table 5.10: Estimated change in profits due to connection to modern utilities

\begin{tabular}{|c|c|c|}
\hline & Urban & Rural \\
\hline In Quetzales per month & & \\
\hline Electricity & $-1,445$ & $399^{* *}$ \\
\hline Water $^{2}$ & 2,518 & $1,062^{* * *}$ \\
\hline Fixed phone & 7,585 & -395 \\
\hline Cellular phone & 15,644 & $8,663^{* *}$ \\
\hline As proportion of profits & & \\
\hline Electricity & -.88 & $.65^{* *}$ \\
\hline Water & 1.5 & $1.7^{* * *}$ \\
\hline Fixed phone & 4.6 & -.65 \\
\hline Cellular phone & 9.6 & $14.2^{* *}$ \\
\hline Observations & 634 & 478 \\
\hline
\end{tabular}


From the regression model coefficients, it is possible to estimate the average impact that each of the utility services has on the profitability of the micro-enterprise (Table 5.10). Perhaps of greatest interest are the figures which express the additional profit attributable to utility services as a percentage of the average profit of micro-enterprises that do not enjoy access to the corresponding services. These show that the value of these services to micro-enterprises is very large indeed. For example, micro-enterprises without electricity in the rural areas have profits that are $65 \%$ higher on average than micro-enterprises with electricity. The corresponding figure for water is $170 \%$. By far the largest effect is that of the cellular telephone, which raises profitability by $1420 \%$. This effect appears implausibly large, and it is possible that the cellular telephone is picking-up some other unobserved variable that is important for profitability and which may not be captured either by the locality population or by the municipality fixed-effect; for example, proximity to a markets.

\subsection{Health benefits}

It is widely believed that modern infrastructure services have an important link with household health. Safe water and basic sanitation reduce exposure to waterborne diseases such as diarrhea and cholera. Garbage collection improves hygiene and reduces the presence of parasites. Use of modern cooking fuels, such as propane gas, reduces exposure to indoor air pollution.

Women participating in the qualitative poverty study, seemed to be particularly aware of the health benefits that had come about as a result of receiving access to water and sanitation services (Table 5.11).

\section{Table 5.11: Impressions of water and sanitation health linkages from qualitative poverty study}

\footnotetext{
'Nosotros...antes ibamos a traer agua en los pozos que hay en los barrancos. El agua era sucia y estaba lejos, nos costaba mucho, sufrimos con el acarreo del agua... Ahora el agua llega a la casa y es limpia, eso nos ha ayudado en la salud de la familia... Ahora hay muy pocas enfermedades pero es por descuido de la gente... también hay letrinas, todo eso nos ha ayudado en nuestra salud.' K'iche Woman, Qualitative Poverty Study.

'[Tener agua] ha mejorado la salud de la familia porque no hay muchas enfermedades del estómago (diarrea)... ahora las mujeres ya no sufren... ya no van al barranco a traer agua.' K'iche Woman, Qualitative Poverty Study

'El río queda lejos y se seca durante el verano... cuando no había agua se iban las mujeres por día a acarrear agua de los ríos... Antes, cuando no teníamos agua, era un sacrificio, peligroso y debajo de la lluvia. Ahora estamos mejor, antes nos bañábamos a veces hasta cada tres días y esto produce enfermedad, habia mucho olor feo... Las mujeres lavan los trastos porque si no se hace esto trae enfermedad, sirve para la higiene.' Q'eqchi Woman, Qualitative Poverty Study.

'[Con el agua entubada] ha mejorado el problema de tomar agua del río crudo y hay menos niños que se enferman... en la casa cloran el agua de tomar.' Ladina Woman, Qualitative Poverty Study.
}

To gain an initial impression of the extent of the correlation between health and access to modern utilities, a series of cross-tabulations are performed. The cross-tabulations distinguish between children and infants as well as between urban and rural areas.

The first of these relates to the relationship between access to piped water and sanitation and the incidence of diarrhea among children (Table 5.12). In urban areas, no significant correlation was found 
between access to water and sanitation and incidence to diarrhea. In rural areas, however, two variables are found to be statistically significant both for children and infants, namely possession of a toilet collected to drainage and purchase of bottled water. Interesting, self-treatment of piped water supply does not show a significant correlation with the incidence of diarrhea. The presence of piped water in the community (though not in the dwelling) is also correlated with the incidence of diarrhea in the case of children but not of infants. However this is expected in that infants tend to be breastfed and are hence less exposed to impurities in water.

Table 5.12: Cross-tabulation of incidence of diarrhea and access to water and sanitation (Proportion of children who had diarrhea)

\begin{tabular}{|c|c|c|c|c|c|c|}
\hline & \multicolumn{3}{|c|}{ Urban } & \multicolumn{3}{|c|}{ Rural } \\
\hline & \multicolumn{2}{|c|}{ Service } & \multirow{2}{*}{$\begin{array}{c}\text { Pearson } \\
\text { Test }\end{array}$} & \multicolumn{2}{|c|}{ Service } & \multirow{2}{*}{$\begin{array}{c}\text { Pearson } \\
\text { Test }\end{array}$} \\
\hline & Yes & No & & Yes & No & \\
\hline Infants: 0-12 months old & & & & & & \\
\hline Piped water in dwelling or yard & .26 & .50 & & .33 & .30 & \\
\hline Community covered by piped water & .50 & .50 & & .27 & .31 & \\
\hline Dwelling connected to sewerage & .25 & .40 & & .33 & .32 & \\
\hline Toilet connected to drainage & .24 & .40 & & .17 & .31 & * \\
\hline Latrine & .32 & .40 & & .33 & .31 & \\
\hline Excusado lavable & .43 & .40 & & .31 & .31 & \\
\hline Only treats water & .33 & .32 & & .33 & .31 & \\
\hline Only buys bottled water & .23 & .32 & & .05 & .31 & ** \\
\hline Treats and buys bottled water & .29 & .32 & & .33 & .31 & \\
\hline \multicolumn{7}{|l|}{ Children: 13-59 months old } \\
\hline Piped water in dwelling or yard & .27 & .29 & & .37 & .20 & \\
\hline Community covered by piped water & .35 & .21 & & .32 & .44 & ** \\
\hline Dwelling connected to sewerage & .25 & .31 & & .30 & .39 & \\
\hline Toilet connected to drainage & .24 & .33 & & .16 & .35 & ** \\
\hline Latrine & .32 & .33 & & .40 & .35 & \\
\hline Excusado lavable & .29 & .33 & & .40 & .35 & \\
\hline Only treats water & .27 & .26 & & .39 & .37 & \\
\hline Only buys bottled water & .22 & .26 & & .14 & .37 & *** \\
\hline Treats and buys bottled water & .36 & .26 & & .43 & .37 & \\
\hline
\end{tabular}

The same exercise is performed for the incidence of respiratory illnesses, cross-tabulated against use of fuel wood for cooking (Table 5.13). Those households that do use fuel wood are further sub-divided according to whether or not they have some kind of chimney for ventilation of the kitchen. It is important to note that the definition of 'respiratory illnesses' used in the ENCOVI questionnaire is rather vague, identifying whether or not children had suffered from a very broad range of complaints - including cold, cough, bronchitis, chokes or respiratory infections-during the previous month. The results show that (in most cases) the use of fuel wood in the home is not significantly correlated with the incidence of respiratory disease. However, what does seem to matter quite significantly is whether households burning fuel wood have a smoke escape in the kitchen. 
Table 5.13: Cross-tabulation of incidence of respiratory illness and access to basic services (Proportion of children)

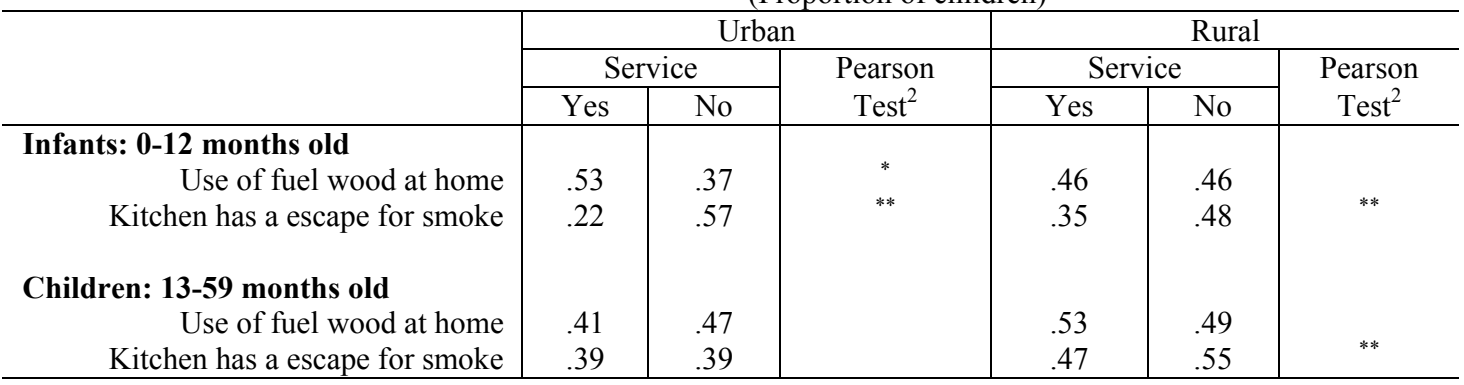

Notes: Refers to illness during the month previous to the survey.

Source: World Bank calculations using the ENCOVI 2000, Instituto Nacional de Estadística - Guatemala

It is interesting to compare these results with those from a second source of data on this issue: the National Maternal and Infant Health Survey 1998/9. This survey, which falls into the broad category of Demographic and Health Surveys, has a much tighter definition of what constitutes an acute respiratory illness. This is defined as a child manifesting at least two of the following three symptoms simultaneously: coughing, fever and breathing in quick short breaths. Given the more stringent definition, the proportion of children reporting respiratory illness in the DHS (at around 20\%) is substantially lower than in the ENCOVI (at around 40\%). Moreover, the equivalent cross-tabulation for the DHS data, shows a significant correlation between cooking with fuel wood and incidence of respiratory illness. The correlation is particularly strong in the case of infants, who (due to their lack of mobility) tend to spend more time close to the mother while she is cooking (Table 5.14). Unfortunately, the DHS does not include questions about kitchen ventilation and hence it is not possible to make that comparison with the ENCOVI data.

Table 5.14: Cross-tabulation of incidence of acute respiratory illness and access to modern fuels (Proportion of children)

\begin{tabular}{c|c|c|c}
\hline & \multicolumn{2}{|c|}{ Service } & Pearson \\
Test
\end{tabular}

Notes: Refers to illness during the two weeks previous to the survey.

Null hypothesis (homogeneity of users and non-users) is rejected at: *** $99 \%, * 90 \%$.

Source: Torres, (2001) based on Guatemala National Maternal and Infant Health Survey 1998/9.

As well as looking at links between specific types of services and specific types of illnesses, it is interesting to consider the overall impact of modern utilities on the production of health at the household level. In the health literature, stunting (or the ratio of height for age in children) is considered a good stock measure of the accumulated health experiences of the child throughout life. Simple crosstabulations of stunting rate against a range of access variables show that children living in households with modern services are significantly less likely to experience stunting. The differences are up to a factor of two in the case of some services. 
Table 5.16: Cross tabulation of stunting rate against access to modern utilities

(Proportion of children)

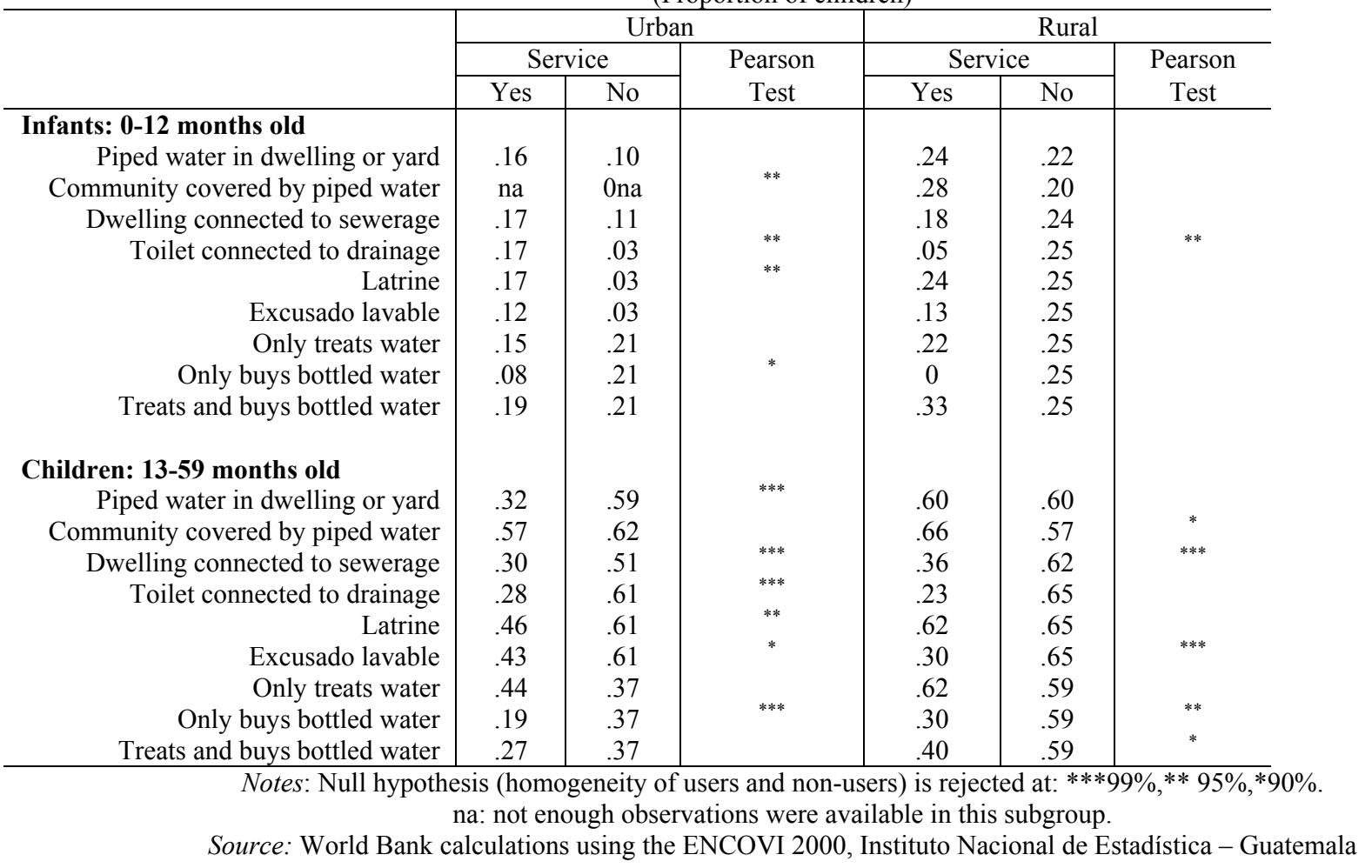

However, such cross-tabulations are at best inconclusive since they do not control for the impact of many other health-related variables that are likely to be correlated with access to utility services, such as household income, geographical location, educational attainment, and a variety of other socioeconomic and demographic factors. While in principle it would seem relatively straightforward to control for these in a multivariate regression framework, there are a number of more serious methodological problems that lend caution to modeling the impact of modern utility services on health outcomes.

First, in the case of parentally-reported incidence of disease (such as whether or not children had diarrhea or respiratory illnesses) there may be serious reporting bias, with health-conscious parents being more likely to detect and report the presence of these problems among their children. In this sense, the stunting variable, based on anthropometric measurements, provides a more objective indicator of health status.

Second, there is the serious issue of the potential endogeneity of access to modern utilities in the health production function. That is to say that not only do modern utilities contribute to health, but households with unobserved preferences for health are also more likely to connect to modern utilities. Failure to take this into account could be expected to lead to biased coefficient estimates. The analysis of microenterprise profitability already illustrated how it can be possible to overcome endogeneity problems by using two stage instrumental variables techniques, with the community availability variable acting as an instrument. However, in the case of health production functions, the endogeneity problem affects not only the modern utility coverage variables but also many of the other key explanatory variables, such as family demographics and hygiene behavior. The shear number of potentially endogenous variables complicates the search for instruments and can make the estimation process computationally intractable. 
For both of these reasons, no further modeling is attempted here. However, the health chapter of the Guatemala Poverty Assessment incorporates a reduced form health production function estimation that incorporates coverage of modern utility services (with appropriate instrumentation). The reader is referred to the corresponding paper for more details (Marini and Gragnolati, 2001). In brief, the main finding of interest is that access to piped water and use to bottled water are both found to make a positive and significant contribution to the height of children in urban areas, but not rural areas. While use of propane gas in the household is found to have a positive and significant effect on height overall.

\section{Conclusions and Recommendations}

Evidence from the Guatemala LSMS 2000 shows that households that have access to modern utility services obtain important benefits.

- First, the cost of modern utility services is often considerably lower than the corresponding traditional alternative. The clearest example is that of households without electricity who pay implicit prices of more than US\$11 per kilowatt-hour (more than 80 times the price of electricity) to illuminate with candles and wick lamps and power appliances with dry cell batteries.

- Second, access to modern services can substantially enhance the productivity of households and household-based micro-enterprise. Rural households with access to piped water and liquid propane gas for cooking, save around six man-hours per week compared with households who must go out to collect water and fuel wood. Furthermore, micro-enterprises with access to water and electricity are twice as profitable than comparable enterprises without access to these services, and the effect of a cellular telephone on micro-enterprise profitability is even larger.

- Third, some traditional substitutes for modern utility service are associated with adverse health impacts and may contribute to infant mortality. Although it is difficult to isolate the underlying causality, children from households with access to piped water and adequate sanitation are significantly less likely to suffer from diarrhea and overall physical stunting.

These benefits serve to highlight the importance of the commitments made by the Government of Guatemala at the time of the Peace Accords: to improve access of modern utilities services to traditionally disadvantaged groups. The events of recent years demonstrate that the commitments made in the Peace Accords have been honored. Since 1996, there have been major structural reforms in the electricity and telecommunications sectors designed to improve efficiency and promote investment. Furthermore, resources channeled towards rural expansion of electricity, water, and sanitation infrastructure have approximately tripled; both as a result of earmarking privatization revenues and due to an overall increase in the resources allocated to social funds.

Overall about $70 \%$ of Guatemalan households now have water and electricity. These services are close to universal in urban areas, but reach little more than half of rural households. Almost $90 \%$ of households have some kind of basic sanitation, though fewer than half of these have sewerage. About $20 \%$ of households subscribe to either a fixed line and/or a cellular telephone service. Around $17 \%$ of Guatemalan households do not have access to any kind of modern network utility service, leading a 
completely traditional lifestyle. This proportion rises to $33 \%$ in rural areas, an $40 \%$ among households in the lowest consumption quintile. Middle-income households tend to have only water and electricity services, while only among households in the highest consumption quintile do a majority also have sewerage and telephone. Interestingly, households who only have one utility service (23\% in all) are most likely to choose electricity, even when other services (such as piped water) are available in their communities.

As a result there has been an appreciable acceleration in the rate of expansion of service coverage. The coverage indices for electricity, water and sanitation increased by about 14 percentage points from 1997/00 versus about 11 percentage points for the period 1993/96. Given the effects of population growth, this represents a substantial increase in the rate of new connections from around 80,000 per year in the years prior to the Peace Accords to around 115,000 per year in the years following the Peace Accords. Moreover, the probability that a household without access received a water or electricity connection rose from 0.19 in the years $1993 / 96$ to 0.35 in the years $1999 / 00$.

These increases in service coverage have begun to reverse traditional inequities in access to services. It is noteworthy that poor, rural and indigenous households have all seen their probability of receiving service more than double following the Peace Accords, increasing more than for any other group in society. However, even this substantial improvement has not been enough to offset their traditional disadvantage, so that in absolute terms these groups still remain the least likely to receive services.

Aided by the rapid expansion of cellular telephony, the overall teledensity index for Guatemala has risen almost fivefold from 4.2 to 19.7 over the period 1997/01. Although about half of the new cellular subscriptions are second telephones for the richest $20 \%$ of the population, they are also playing an important role in rural areas where they have become as common as fixed line telephones and have begun to be used to provide informal public telephone services. The network of formal public telephones in rural areas has increased by $80 \%$ since the Peace Accords. As a result, $50 \%$ of rural households now have a public telephone in their community, and $80 \%$ of rural households live within 6 kilometers (or about half an hour) of a public telephone.

Notwithstanding these improvements, coverage rates in Guatemala are still only about average for the Central American region, and a significant coverage gap remains. Over half a million households lack access to electricity and piped water, some 200,000 households are without any form of sanitation, and another 200,000 households in the largest cities are still relying on in situ sanitation as opposed to sewerage. Even if current - historically high-levels of expenditure and effort are sustained, with population growth of $2.6 \%$ per annum it will still take around 10 years to reach universal coverage for electricity, water, and sewerage. The overall cost to the country is estimated at around US\$1 billion.

However, achieving universal coverage is not merely about building infrastructure networks. The evidence shows that about a third of households without electricity and water live in neighborhoods where these services are available, but simply fail to make a connection. Reasons appear to include high connection charges, cultural priorities, and the responsiveness of utilities to customer requests. Complementary policy measures are therefore required to encourage these households to connect to existing networks. 
There has been a conscious government policy decision to keep water and electricity tariffs artificially low. To some extent this is understandable given that providing access to utilities services is only ultimately meaningful if these are affordable for poor households to use. However, the evidence suggests that this has not always had the desired consequences, and that the disadvantages of this policy are quite substantial.

In the electricity sector, the 'tarifa social' introduced following privatization of the distribution companies largely fails to reach poor households. This policy keeps domestic tariffs for those consuming up to 300 kilowatt-hours per month capped at US\$0.08 per kilowatt-hour. However, the evidence suggests that this measure has only a very modest impact on poor households. Owing to relatively low connection rates among poor households and to the relatively high consumption threshold for the 'tarifa social', about $65 \%$ of the beneficiaries are non-poor households who together capture $90 \%$ of the total value of the subsidy, while $60 \%$ of poor households receive no benefits from the scheme at all since they do not have an electricity connection. Lowering the threshold from 300 to 100 kilowatthours per month would improve matters somewhat by lowering the number of non-poor beneficiaries to $55 \%$ and the leakage rate to $75 \%$, and reducing the annual costs of the policy by $80 \%$. However, even this still leaves a great deal to be desired.

A much more pro-poor policy would be to channel these resources towards expanding coverage of electricity to unserved households. It is important to recall that the-largely poor-households without access to electricity pay an estimated US $\$ 11$ per $\mathrm{kWh}$, compared with full cost electricity tariffs of US\$0.11 to US\$0.15 per $\mathrm{kWh}$. From this perspective, it would appear to make much more sense to channel the US\$50 million annual cost of the 'tarifa social' towards increasing connections to unserved households. It is estimated that an additional 50,000 new connections each year could be financed in this way. Moreover, given that over $70 \%$ of households without electricity belong to the poorest segments of the population, such a policy would be very effective at reaching the poor.

In the water and sanitation sector, tariffs are well below true economic costs and international parameters of willingness to pay. Households pay bills of less than US\$2 per month in Guatemala City, and less than US\$1 per month in other urban areas. The underlying tariffs are barely US\$0.10 per cubic meter compared with typical costs of around US $\$ 0.40$ per cubic meter for the Latin American region. In spite of these low tariffs, as many as $30 \%$ of households with piped water reported that they did not pay for the service in the last month, compared with only $8 \%$ for electricity. As a result, households spend barely $0.5 \%$ of their budgets on water and sanitation services, which is a fraction of the $3 \%-5 \%$ World Health Organization guideline for what households are typically willing to pay. Moreover, many households spend three times as much on bottled water as on piped water.

While low water tariffs may seem attractive, there is substantial evidence that the precarious financial position of water utilities is contributing to a very poor quality of service. Three quarters of households with piped water feel it necessary to either buy bottled water or perform some kind of self-treatment. It is particularly striking that the practice regular boiling drinking water is equally prevalent among households with and without piped water (some $40 \%$ of both groups). Moreover, households report that on average they receive only 17 hours of water per day and face 3.6 days per month without water.

In conclusion, the key policy recommendations that emerge from the assessment are as follows. 
- To maintain and, if possible, increase the current level of resources channeled towards the expansion of modern utility services so as to reach universal coverage within a 10 year horizon.

- To try and improve further the ability of service expansion programs to target traditionally disadvantaged groups, in particular, poor, rural and indigenous households.

- To develop a strategy for removing the barriers that prevent a significant proportion of excluded households from making connections to services even when these are available in their communities.

- To find new financial resources for the FONDETEL rural telephony program and to consider using these to subsidize the extension of cellular networks into commercially marginal areas.

- To reform the 'tarifa social' policy by at least reducing the eligibility threshold to 100 kilowatt-hours per month, and preferably replacing it with a program to fund 50,000 new connections per year.

- To allow water tariffs to rise to a level that allows water utilities to become financial sustainable and thereby improve the quality of service that they offer to the public.

- To complement expansion of water and sanitation programs with measures to improve household hygiene practices so as to reap the full health benefits of the service.

- To complement expansion of electricity and telecommunications coverage in rural areas with measures to promote the productive use of these services by micro-enterprises. 


\section{Bibliography}

Centro de Investigaciones Económicas Nacionales (CIEN), 1998, Revisión del Programa de Inversión Pública de Mediano Plazo: Sector Infraestructura-Electricidad y Telecomunicaciones, Mimeo, The World Bank, Washington DC.

Centro Pan-Americano de Ingenieria Sanitaria (CEPIS), 2000, Evaluación de los Servicios de Agua Potable y Saneamiento 2000 en las Américas: Informe Analítico de Guatemala, Mimeo, Pan-American Health Organization, Washington DC.

Comisión Nacional de Energía Eléctrica (CNEE), 2001, www.cnee.gob.gt.

ESA Consultores, 2001, Guatemala Agua y Saneamiento: Apuntos para la Preparación de una Nota Sectorial, Mimeo, Inter-American Development Bank, Washington DC.

Foster, 2001 Condominial Water and Sewerage Systems: Costs of Implementation of the Model. El Alto-Bolivia Pilot Project. Economic and Financial Evaluation, Water and Sanitation Program, Lima, Perú.

Foster, V. and Tre, J.P., 2000, 'Measuring the impact of energy interventions on the poor: an illustration from Guatemala.' Conference Volume 'Infrastructure for Development: Private Solutions and the Poor', Private Provision of Infrastructure Advisory Facility (PPIAF), Department for International Development (DIFD) and the World Bank, London, United Kingdom

Instituto Nacional de Electrificación (INDE), 2001, Plan de Electrificación Rural: Gerencia de Electrificación Rural y Obras: Informe de Avance, Mimeo, Ciudad de Guatemala.

Marini, A. and Gragnolati, M. (2001) 'Nutrition and Poverty in Guatemala', Background Paper for the Guatemala Poverty Assessment, The World Bank Group, Washington DC (forthcoming).

Solo, T., 1999, 'Guatemala's Medley of Water Providers: Los Aguateros no Tienen Quien les Regule', Chapter 7 from The Other Private Participation in Water and Sanitation: Tales of Small Independent Providers in Latin American Cities, Mimeo, The World Bank Group, Washington DC.

Torres, J., Infant mortality and morbidity from exposure to indoor air pollution in Guatemala, Consulting Report to the World Bank, July 2001.

Vakis, R. (2001) 'Guatemala: Livelihoods, Labor Markets and Rural Poverty', Background Paper for Guatemala Poverty Assessment, The World Bank Group, Washington DC (forthcoming).

Walker, I., Ordoñez, F., Serrano, P. and Halpern, J., 2000, Potable Water Pricing and Poor: Evidence from Central America on the Distribution of Subsidies and the Demand for Improved Services, Policy Research Working Paper No. 2468, The World Bank Group, Washington DC.

World Bank, 1999, Ayuda Memoria de la Misión de Supervisión del Proyecto de Asistencia Técnica para la Participación Privada en Infraestructura (Préstamo 4149-GU), Mimeo, Washington DC.

Zúñiga, A., 1999, Análisis de los Fondos de Inversión Social, Mimeo, The World Bank, Washington DC. 


\section{Data Annex}

\section{A. Summary Statistics for Regressions}

\section{Table A1: Summary statistics for the regression of determinants of the price per efficient kilowatt-hour}

\begin{tabular}{l|c|c|c|c}
\hline & National & Urban & Rural & Difference \\
\hline Quetzales per net kwh consumed & 10.8 & 11.9 & 9.9 & \\
Household head characteristics & & & & \\
$\quad$ Sex (1 if male) & 0.82 & 0.77 & 0.85 & $* * *$ \\
Age (years) & 44.29 & 44.49 & 44.14 & \\
Ethnicity (1 if indigenous) & 0.39 & 0.26 & 0.49 & $* * *$ \\
$\quad$ Language (1 if speaks Spanish) & 0.92 & 0.98 & 0.88 & $* * *$ \\
$\quad$ Education (\# of years) & 4.06 & 6.47 & 2.22 & $* * *$ \\
Household size (\# of adults) & 2.90 & 2.85 & 2.94 & $* *$ \\
Expenditure (thousands of Quetzales) & 7.72 & 12.13 & 4.35 & $* * *$ \\
Area (1 if urban) & 0.43 & & & $*$ \\
Micro enterprise (1 if operates in dwelling) & 0.21 & 0.23 & 0.20 & $*$ \\
Use of electricity & 0.73 & 0.95 & 0.56 & $* * *$ \\
Use of kerosene & 0.25 & 0.04 & 0.40 & $* * *$ \\
Use of propane & 0.46 & 0.78 & 0.20 & $* * *$ \\
Use of fuel wood & 0.74 & 0.46 & 0.96 & $* * *$ \\
\cline { 1 - 3 } Population size & $2,183,071$ & 947,643 & $1,235,428$ & \\
\hline
\end{tabular}

Significantly different (urban from rural) at: * 90\% level, ** 95\% level, *** 99\% level.

Source: World Bank calculations using the ENCOVI 2000, Instituto Nacional de Estadística - Guatemala

Table A2: Regression of determinants of the price per efficient kilowatt-hour

\begin{tabular}{l|c|c|c}
\hline & National & Urban & Rural \\
\hline Household head characteristics & & & \\
Sex (1 if male) & -0.015 & -0.005 & -0.046 \\
Age (years) & 0.0001 & -0.001 & 0.001 \\
Ethnicity (1 if indigenous) & $-0.181^{* * *}$ & $-0.100^{* *}$ & $-0.254^{* *}$ \\
Language (1 if speaks Spanish) & 0.147 & 0.283 & 0.148 \\
Education (\# of years) & 0.002 & 0.003 & 0.002 \\
Household size (\# of adults) & 0.002 & 0.010 & -0.004 \\
Expenditure (thousands of Quetzales) & 0.0004 & $0.002^{*}$ & -0.004 \\
Area (1 if urban) & 0.078 & & \\
Micro enterprise (1 if operates in dwelling) & 0.032 & $0.122^{* * *}$ & -0.042 \\
Use of electricity & $-0.833^{* * *}$ & $-1.059^{* * *}$ & $-0.817^{* * *}$ \\
Use of kerosene & $-0.173^{*}$ & 0.014 & -0.181 \\
Use of propane & $-0.285^{* * *}$ & $-0.248^{* * *}$ & $-0.295^{* * *}$ \\
Use of fuel wood & $-0.225^{* * *}$ & $-0.159^{* * *}$ & $-0.621^{* * *}$ \\
Constant & $0.773^{* * *}$ & $0.673^{* *}$ & $1.282^{* * *}$ \\
\hline R ${ }^{2}$ & .0931 & .1301 & .0962 \\
Population size & $2,169,354$ & 937,759 & $1,231,596$ \\
\hline
\end{tabular}

OLS estimation where dependent variable is log of price of net kilowatts-hour consumed.

Regional dummies were included in the estimation.

Significant at: ${ }^{*} 90 \%$ level, ${ }^{* *} 95 \%$ level, ${ }^{* * *} 99 \%$ level.

Source: World Bank calculations using the ENCOVI 2000, Instituto Nacional de Estadística - Guatemala 
Table A3: Summary statistics for regression on take-up of modern utilities

\begin{tabular}{|c|c|c|c|c|c|c|}
\hline \multirow[t]{2}{*}{ Variable } & \multicolumn{2}{|c|}{ Electricity } & \multicolumn{2}{|c|}{ Water } & \multicolumn{2}{|c|}{ Sanitation } \\
\hline & $\mathrm{N}$ & $\mathrm{Y}$ & $\mathrm{N}$ & $\mathrm{Y}$ & $\mathrm{N}$ & $\mathrm{Y}$ \\
\hline Household head & & & & & & \\
\hline$\%$ of male & $.85^{* *}$ & .80 & $.85^{* * *}$ & .80 & $.84^{*}$ & .81 \\
\hline Age in years & 44 & 44 & $43^{* * *}$ & 45 & 43 & 44 \\
\hline Years of school & $1.6^{* * *}$ & 5.0 & $2.0^{* * * *}$ & 5.0 & $1.6^{* * *}$ & 4.4 \\
\hline$\%$ of indigenous & $.56^{* * *}$ & .33 & $.51^{* * * *}$ & .35 & .41 & .38 \\
\hline$\%$ who speaks Spanish & $.88^{* * * *}$ & .96 & .89 & .95 & $.89^{* *}$ & .93 \\
\hline \multicolumn{7}{|l|}{ Household characteristics } \\
\hline$\%$ with business in dwelling & $.11^{* * * *}$ & .18 & .15 & .18 & $.12^{* * * *}$ & .18 \\
\hline Per capita income ${ }^{1}$ & $3.9^{* * * *}$ & 9.2 & $4.2^{* * * *}$ & 9.3 & $3.6^{* * *}$ & 8.4 \\
\hline$\%$ in urban area & $.20^{* * * *}$ & .56 & $.25^{* * * *}$ & .56 & $.09^{* * * *}$ & .49 \\
\hline \multicolumn{7}{|l|}{ Regional dummies } \\
\hline$\%$ in Metropolitan & $.09^{* * * *}$ & .33 & $.10^{* * * *}$ & .31 & $.06^{* * *}$ & .28 \\
\hline$\%$ in North & $.08^{* * *}$ & .03 & $.10^{* *}$ & .05 & .06 & .08 \\
\hline$\%$ in Northeast & .05 & .07 & $.14^{*}$ & .08 & $.15^{*}$ & .08 \\
\hline$\%$ in Southeast & .09 & .08 & .12 & .08 & $.18^{* * *}$ & .07 \\
\hline$\%$ in Central & .13 & .13 & .12 & .11 & $.08^{* * *}$ & .12 \\
\hline$\%$ in Southwest & .32 & .26 & .24 & .24 & .26 & .25 \\
\hline$\%$ in Petén & $.03^{* * *}$ & .01 & .01 & .02 & $.06^{* * *}$ & .02 \\
\hline Population size & 210,677 & $1,593,209$ & 272,554 & $1,494,239$ & 249,168 & $1,890,371$ \\
\hline Variable & \multicolumn{2}{|c|}{ Sewerage } & \multicolumn{2}{|c|}{ Fixed Phone } & \multicolumn{2}{|c|}{ Cell Phone } \\
\hline & $\mathrm{N}$ & $\mathrm{Y}$ & $\mathrm{N}$ & $\mathrm{Y}$ & $\mathrm{N}$ & $\mathrm{Y}$ \\
\hline Household head & & & & & & \\
\hline$\%$ of male & $.85^{* * *}$ & .76 & .80 & .77 & $.76^{* * * *}$ & .84 \\
\hline Age in years & 44 & 45 & $42^{* * * *}$ & 48 & $45^{\text {***k }}$ & 42 \\
\hline Years of school & $3.1^{* * *}$ & 6.8 & $5.1^{* * *}$ & 9.8 & $5.3^{* * *}$ & 10.4 \\
\hline$\%$ of indigenous & $.42^{* * * *}$ & .23 & $.28^{* * *}$ & .11 & $.25^{* * *}$ & .11 \\
\hline \% who speaks Spanish & $.96^{* * *}$ & .99 & $.985^{*}$ & .994 & $.986^{* *}$ & .997 \\
\hline \multicolumn{7}{|l|}{ Household characteristics } \\
\hline$\%$ with business in dwelling & .16 & .19 & $.17^{* *}$ & .22 & .19 & .19 \\
\hline Per capita income ${ }^{1}$ & $5.6^{* * *}$ & 12.9 & $8.4^{* * *}$ & 21.0 & $10.2^{* * * *}$ & 20.9 \\
\hline$\%$ in urban area & $.48^{* * *}$ & .87 & $.76^{* * *}$ & .90 & $.70^{* * *}$ & .83 \\
\hline \multicolumn{7}{|l|}{ Regional dummies } \\
\hline$\%$ in Metropolitan & $.23^{* * * *}$ & .46 & $.37^{* * * *}$ & .58 & $.49^{* * *}$ & .67 \\
\hline$\%$ in North & .04 & .02 & $.03^{* *}$ & .02 & $.02^{* * *}$ & .01 \\
\hline$\%$ in Northeast & $.12^{*}$ & .06 & .09 & .07 & $.12^{* * *}$ & .08 \\
\hline$\%$ in Southeast & .07 & .05 & .05 & .04 & $.06^{* * *}$ & .03 \\
\hline$\%$ in Central & .12 & .14 & $.13^{* * *}$ & .08 & $.09^{* *}$ & .06 \\
\hline$\%$ in Southwest & .28 & .23 & $.26^{* * * *}$ & .18 & $.17^{* * *}$ & .12 \\
\hline$\%$ in Petén & $.02^{* * *}$ & .001 & .01 & .01 & .01 & .01 \\
\hline Population size & 271,823 & 828,331 & 454,470 & 328,104 & 617,354 & 209,711 \\
\hline
\end{tabular}


Table A4: Summary statistics for hedonic rental model

\begin{tabular}{|c|c|c|c|}
\hline Variable / Region & $\begin{array}{c}\text { Metropolitan } \\
\text { (urban and rural) }\end{array}$ & $\begin{array}{c}\text { Urban } \\
\text { (non-Metropolitan) }\end{array}$ & $\begin{array}{c}\text { Rural } \\
\text { (non-Metropolitan) }\end{array}$ \\
\hline Monthly rent (quetzales) & 888 & 431 & 190 \\
\hline Proportion in urban area & .86 & & \\
\hline Proportion with walls made of & & & \\
\hline Block & .60 & .55 & .29 \\
\hline Adobe & .10 & .24 & .37 \\
\hline Wood & .07 & .10 & .20 \\
\hline Proportion with roofs made of & & & \\
\hline Concreto & .33 & .15 & .02 \\
\hline Metal & .62 & .72 & .77 \\
\hline Tile & .005 & .09 & .18 \\
\hline Straw or palm & 0 & .001 & .01 \\
\hline Proportion with floors made of & & & \\
\hline Cement or clay bricks & .27 & .17 & .05 \\
\hline Cement & .32 & .45 & .38 \\
\hline Ceramic or granite & .22 & .15 & .03 \\
\hline Soil or sand & .19 & .22 & .53 \\
\hline Connection to & & & \\
\hline Water & .85 & .89 & .59 \\
\hline Drainage & .67 & .74 & .10 \\
\hline Electricity & .95 & .91 & .59 \\
\hline Telephone & .42 & .27 & .03 \\
\hline Number of rooms & 3.0 & 2.5 & 1.7 \\
\hline Number of rooms for business & .13 & .22 & .10 \\
\hline Exclusive use of & & & \\
\hline Kitchen & .96 & .96 & .97 \\
\hline Water & .68 & .71 & .48 \\
\hline Sanitary service & .83 & .80 & .70 \\
\hline Age of dwelling (years) & 17.4 & 18.3 & 16.3 \\
\hline Really rented dwellings & .13 & .15 & .02 \\
\hline
\end{tabular}

Metropolitan includes urban and rural in this region, while urban and rural exclude the Metropolitan region. Source: World Bank calculations using the ENCOVI 2000, Instituto Nacional de Estadística - Guatemala 
Table A5: Regression results for hedonic rental model

\begin{tabular}{|c|c|c|c|}
\hline Variable / Region & $\begin{array}{c}\text { Metropolitan } \\
\text { (urban and rural) }\end{array}$ & $\begin{array}{c}\text { Urban } \\
\text { (non-Metropolitan) }\end{array}$ & $\begin{array}{c}\text { Rural } \\
\text { (non-Metropolitan) }\end{array}$ \\
\hline Urban area & $-.39^{*}$ & & \\
\hline Walls made of & & & \\
\hline Block & .13 & $.17^{* *}$ & $.28^{* * *}$ \\
\hline Adobe & .004 & $.12^{*}$ & .10 \\
\hline Wood & .09 & -.10 & .03 \\
\hline Roofs made of & & & \\
\hline Concreto & $.31^{* *}$ & .03 & .03 \\
\hline Metal & .11 & $-.15^{* *}$ & -.10 \\
\hline Tile & -.07 & $-.26^{* * *}$ & -.10 \\
\hline Straw or palm & - & -.20 & -.15 \\
\hline Floors made of & & & \\
\hline Cement/ clay bricks & .02 & .10 & -.16 \\
\hline Cement & -.13 & -.04 & -.17 \\
\hline Ceramic or granite & .08 & .04 & -.17 \\
\hline Soil or sand & $-.38^{* *}$ & $-.25^{* *}$ & $-.36^{*}$ \\
\hline Connection to & & & \\
\hline Water & $.39^{* * *}$ & .003 & -.01 \\
\hline Drainage & .02 & $.08^{*}$ & $16^{* *}$ \\
\hline Electricity & .09 & $.27^{* * *}$ & $.17^{* * *}$ \\
\hline Telephone & $.45^{* * *}$ & $.20^{* * *}$ & $.28^{* * *}$ \\
\hline \# of rooms & $.09^{* * *}$ & $.14^{* * *}$ & $.13^{* * *}$ \\
\hline \# of rooms for business & $-.10^{*}$ & $.06^{*}$ & .02 \\
\hline Exclusive use of & & & \\
\hline Kitchen & -.07 & .02 & .07 \\
\hline Water & -.04 & -.01 & $.11^{* *}$ \\
\hline Sanitary service & $.27^{* *}$ & $.15^{* * *}$ & $.07^{*}$ \\
\hline Age of dwelling & -.003 & .0002 & -.0001 \\
\hline Rented & $-.19^{* * *}$ & $-.30^{* * *}$ & $-.38^{* * *}$ \\
\hline Constant & $5.28^{* * *}$ & $4.36^{* * *}$ & $4.20^{* * *}$ \\
\hline $\mathrm{R}^{2}$ & .7694 & .6527 & .5375 \\
\hline Population size & 446,882 & 429,432 & $1,029,361$ \\
\hline
\end{tabular}

Results of OLS regressions where the dependant variable is the logarithm of the monthly rent for the dwelling. Census-tract fixed-effects were included in each of the estimations.

Metropolitan includes urban and rural in this region, while urban and rural exclude the Metropolitan region. Significant at: ${ }^{*} 90 \%$ level, ${ }^{* *} 95 \%$ level, ${ }^{* * *} 99 \%$ level.

Source: World Bank calculations using th e ENCOVI 2000, Instituto Nacional de Estadística - Guatemala 
Table A6: Summary statistics for model of probability of having a micro-enterprise

\begin{tabular}{|c|c|c|c|}
\hline & No enterprise & Enterprise & Wald test ${ }^{3}$ \\
\hline \multicolumn{4}{|l|}{ Household head characteristics } \\
\hline Male & .77 & .81 & \\
\hline Age & 44 & 47 & *** \\
\hline Years of school & 6.5 & 6.6 & * \\
\hline Speaks Spanish & .98 & .99 & \\
\hline Indigenous & .26 & .29 & \\
\hline \multicolumn{4}{|l|}{ Household characteristics } \\
\hline Number of adults & 2.8 & 3.2 & *** \\
\hline Urban area & .43 & .48 & ** \\
\hline Rural area & .57 & .52 & ** \\
\hline \multicolumn{4}{|l|}{ Modern utilities availability } \\
\hline Electricity & 1 & 1 & \\
\hline Water $^{2}$ & .94 & .97 & ** \\
\hline Fixed phone & .68 & .73 & *** \\
\hline Cellular phone & .66 & .63 & * \\
\hline \multicolumn{4}{|l|}{ Modern utilities coverage } \\
\hline Expenditure in electricity ${ }^{4}(\mathrm{Q})$ & .43 & 27 & *** \\
\hline Electricity & .95 & .97 & *** \\
\hline Water $^{2}$ & .87 & .90 & *** \\
\hline Fixed phone & .29 & .39 & *** \\
\hline Cellular phone & .19 & .19 & ** \\
\hline Minutes to closest public phone & 11 & 8 & *** \\
\hline \multicolumn{4}{|l|}{ Region } \\
\hline Metropolitan & .50 & .44 & \\
\hline North & .03 & .03 & ** \\
\hline Northeast & .06 & .05 & \\
\hline Southeast & .05 & .06 & *** \\
\hline Central & .12 & .14 & \\
\hline Southwest & .18 & .19 & \\
\hline Northwest & .05 & .06 & \\
\hline Petén & .02 & .02 & ** \\
\hline Population size & $1,721,709$ & 455,641 & \\
\hline
\end{tabular}

1: Refers only to enterprises that operate in dwelling. 2: In dwelling or yard.

3: Null hypothesis (equality of enterprise owners and non-owners) is rejected at: ${ }^{* *} 90 \%,{ }^{* *} 95 \%,{ }^{*} 90 \%$. 4: For business purposes, only.

Source: World Bank calculations using the ENCOVI 2000, Instituto Nacional de Estadística - Guatemala 
Table A7: Summary statistics for characteristics of households with micro-enterprises

\begin{tabular}{|c|c|c|c|}
\hline & National & Rural & Urban \\
\hline \multicolumn{4}{|l|}{ Household head characteristics } \\
\hline Male & 0.81 & 0.82 & 0.81 \\
\hline Age & 46.90 & 46.10 & 47.54 \\
\hline Years of school & 4.54 & 2.50 & 6.16 \\
\hline Speaks Spanish & 0.93 & 0.87 & 0.98 \\
\hline Indigenous & 0.40 & 0.52 & 0.31 \\
\hline \multicolumn{4}{|l|}{ Household characteristics } \\
\hline Number of adults & 3.19 & 3.15 & 3.22 \\
\hline Urban area & 0.56 & 0.00 & 1.00 \\
\hline \multicolumn{4}{|l|}{ Modern utilities coverage } \\
\hline Electricity & 0.84 & 0.68 & 0.97 \\
\hline Water $^{2}$ & 0.79 & 0.63 & 0.91 \\
\hline Fixed phone & 0.24 & 0.06 & 0.39 \\
\hline Cellular phone & 0.10 & 0.05 & 0.15 \\
\hline Minutes to closest public phone & 16.10 & 27.64 & 7.00 \\
\hline \multicolumn{4}{|l|}{ Business characteristics } \\
\hline Capital (Q) & 1,0645 & 4,401 & 15,573 \\
\hline Labor (man-hours) & 249 & 207 & 283 \\
\hline Age of business (years) & 10.43 & 10.27 & 10.56 \\
\hline Months worked last year (\#) & 10.75 & 10.63 & 10.85 \\
\hline \multicolumn{4}{|l|}{ Economic activity } \\
\hline Manufacture & 0.33 & 0.35 & 0.31 \\
\hline Services & 0.63 & 0.64 & 0.63 \\
\hline \multicolumn{4}{|l|}{ Provider } \\
\hline Large firm & 0.21 & 0.15 & 0.27 \\
\hline Small firm & 0.32 & 0.34 & 0.31 \\
\hline \multicolumn{4}{|l|}{ Source of finance } \\
\hline Bank / cooperative / NGO & 0.05 & 0.03 & 0.07 \\
\hline Family / friends & 0.10 & 0.09 & 0.12 \\
\hline Providers & 0.01 & 0.01 & 0.02 \\
\hline Savings / assets / inheritance & 0.85 & 0.89 & 0.82 \\
\hline \multicolumn{4}{|l|}{ Type of dwelling } \\
\hline House & 0.94 & 0.92 & 0.96 \\
\hline \multicolumn{4}{|l|}{ Modern utilities availability } \\
\hline Fixed phone & 0.46 & 0.16 & 0.71 \\
\hline Cellular phone & 0.41 & 0.20 & 0.58 \\
\hline Water $^{2}$ & 0.88 & 0.74 & 0.99 \\
\hline Electricity & 0.89 & 0.75 & 1.00 \\
\hline Observations & 1,299 & 726 & 573 \\
\hline
\end{tabular}

1: Refers only to enterprises that operate in dwelling.

2: In dwelling or yard. 


\section{B. Summary Statistics Underlying Figures Presented in Text}

Table B1: Total social fund investments in rural infrastructure since 1993 (US\$ million per year)

\begin{tabular}{l|l|c|c|c|c|c|c|c}
\hline & \multicolumn{9}{|c}{ Electricity } & \multicolumn{5}{c}{ Water and Sanitation } \\
& FIS & FONAPAZ & FSDC & Total & FIS & FONAPAZ & FSDC & Total \\
\hline 1993 & 0 & 0 & 0 & 0 & 0 & 1.0 & 0 & 1.1 \\
1994 & 0 & 0 & 0 & 0 & 0 & 1.0 & 0 & 1.0 \\
1995 & 0 & 0 & 4.0 & 4.0 & 0 & 1.0 & 0 & 5.0 \\
1996 & 0 & 0 & 8.2 & 8.2 & 7.3 & 0.9 & 7.3 & 9.5 \\
1997 & 0 & 0 & 13.9 & 13.9 & 15.9 & 1.9 & 15.9 & 23.2 \\
1998 & 0 & 0 & 23.5 & 23.5 & 16.9 & 1.0 & 16.9 & 43.4 \\
1999 & 0 & 0 & 16.6 & 16.6 & 7.9 & 3.9 & 7.9 & 40.8 \\
2000 & 0 & 0 & 3.3 & 3.3 & 23.6 & 1.0 & 23.6 & 26.2 \\
& & 0 & & & & & & \\
Total & 0 & 0 & 69.5 & 69.5 & 31.1 & 12.8 & 71.7 & 114.5 \\
\hline
\end{tabular}

Table B2: Central American comparison for equity of coverage

(percentage of households)

\begin{tabular}{|c|c|c|c|c|}
\hline & Guatemala & Nicaragua & Panama & El Salvador \\
\hline $\begin{array}{l}\text { Electricity } \\
\text { - } 1^{\text {st }} \text { quintile } \\
\text { - } 2^{\text {nd }} \text { quintile } \\
\text { - } 3^{\text {rd }} \text { quintile } \\
\text { - } 4^{\text {th }} \text { quintile } \\
\text { - } 5^{\text {th }} \text { quintile }\end{array}$ & $\begin{array}{l}37 \\
60 \\
74 \\
87 \\
93\end{array}$ & $\begin{array}{l}54 \\
69 \\
77 \\
85 \\
96\end{array}$ & $\begin{array}{l}27 \\
51 \\
74 \\
83 \\
93\end{array}$ & $\begin{array}{l}27 \\
72 \\
86 \\
93 \\
98\end{array}$ \\
\hline $\begin{array}{l}\text { Water } \\
\text { - } 1^{\text {st }} \text { quintile } \\
\text { - } 2^{\text {nd }} \text { quintile } \\
\text { - } 3^{\text {rd }} \text { quintile } \\
\text { - } 4^{\text {th }} \text { quintile } \\
\text { - } 5^{\text {th }} \text { quintile }\end{array}$ & $\begin{array}{l}50 \\
62 \\
63 \\
76 \\
92\end{array}$ & $\begin{array}{l}29 \\
33 \\
45 \\
54 \\
76\end{array}$ & $\begin{array}{l}22 \\
45 \\
63 \\
73 \\
86\end{array}$ & $\begin{array}{l}58 \\
82 \\
89 \\
94 \\
98\end{array}$ \\
\hline $\begin{array}{l}\text { Sanitation } \\
\text { - } 1^{\text {st }} \text { quintile } \\
\text { - } 2^{\text {nd }} \text { quintile } \\
\text { - } 3^{\text {rd }} \text { quintile } \\
\text { - } 4^{\text {th }} \text { quintile } \\
\text { - } 5^{\text {th }} \text { quintile }\end{array}$ & $\begin{array}{l}73 \\
80 \\
88 \\
94 \\
98\end{array}$ & $\begin{array}{l}72 \\
76 \\
79 \\
81 \\
88\end{array}$ & $\begin{array}{l}64 \\
73 \\
86 \\
92 \\
97\end{array}$ & $\begin{array}{c}71 \\
92 \\
97 \\
99 \\
100\end{array}$ \\
\hline $\begin{array}{l}\text { Telephone } \\
\text { - } 1^{\text {st }} \text { quintile } \\
\text { - } 2^{\text {nd }} \text { quintile } \\
\text { - } 3^{\text {rd }} \text { quintile } \\
\text { - } 4^{\text {th }} \text { quintile } \\
\text { - } 5^{\text {th }} \text { quintile }\end{array}$ & $\begin{array}{c}0 \\
2 \\
6 \\
24 \\
68\end{array}$ & $\begin{array}{c}1 \\
4 \\
10 \\
19 \\
46\end{array}$ & $\begin{array}{c}1 \\
1 \\
3 \\
6 \\
31\end{array}$ & $\begin{array}{c}4 \\
14 \\
32 \\
55 \\
78\end{array}$ \\
\hline
\end{tabular}


Table B3: Historical coverage trends

(percentage of households)

\begin{tabular}{l|c|c|c|c|c|c|c|c|c}
\hline & \multicolumn{3}{|c|}{ Electricity } & \multicolumn{3}{c|}{ Water } & \multicolumn{3}{c}{ Sanitation } \\
& Total & Urban & Rural & Total & Urban & Rural & Total & Urban & Rural \\
\hline 1990 & 46 & 72 & 27 & 38 & 60 & 22 & 55 & 68 & 45 \\
1991 & 47 & 73 & 28 & 39 & 61 & 23 & 55 & 69 & 45 \\
1992 & 49 & 74 & 29 & 42 & 63 & 25 & 58 & 72 & 47 \\
1993 & 50 & 76 & 30 & 44 & 65 & 27 & 60 & 75 & 49 \\
1994 & 52 & 78 & 33 & 46 & 68 & 29 & 63 & 78 & 52 \\
1995 & 55 & 81 & 36 & 50 & 73 & 32 & 67 & 82 & 56 \\
1996 & 58 & 84 & 38 & 53 & 75 & 36 & 71 & 86 & 59 \\
1997 & 61 & 87 & 42 & 57 & 78 & 40 & 75 & 89 & 63 \\
1998 & 65 & 89 & 46 & 61 & 82 & 45 & 79 & 92 & 69 \\
1999 & 67 & 91 & 49 & 65 & 85 & 49 & 83 & 95 & 74 \\
2000 & 73 & 95 & 56 & 69 & 88 & 54 & 87 & 97 & 79 \\
\hline
\end{tabular}

Table B4: Distance to public telephone for rural households

(cumulative percentage of households who live with the distance indicated)

\begin{tabular}{c|c|c|c}
\hline & Within community & Outside community & Overall \\
\hline $1 \mathrm{~km}$ & 86 & 17 & 48 \\
$2 \mathrm{~km}$ & 94 & 32 & 60 \\
$3 \mathrm{~km}$ & 96 & 40 & 66 \\
$4 \mathrm{~km}$ & 97 & 51 & 72 \\
$5 \mathrm{~km}$ & 98 & 61 & 78 \\
$6 \mathrm{~km}$ & 98 & 65 & 80 \\
$7 \mathrm{~km}$ & 98 & 69 & 82 \\
$8 \mathrm{~km}$ & 98 & 76 & 86 \\
$9 \mathrm{~km}$ & 98 & 78 & 87 \\
$10 \mathrm{~km}$ & 98 & 83 & 90 \\
$>10 \mathrm{~km}$ & 100 & 100 & 100 \\
\hline
\end{tabular}

Table B5: Accessibility of public telephones for rural households by region (average distance faced by households)

\begin{tabular}{c|c|c}
\hline & $\begin{array}{c}\text { Physical distance } \\
\text { (kilometers) }\end{array}$ & $\begin{array}{c}\text { Temporal distance } \\
\text { (minutes) }\end{array}$ \\
\hline Metropolitan & 2.7 & 28 \\
Northeast & 3.2 & 22 \\
Southwest & 3.6 & 24 \\
Southeast & 3.7 & 33 \\
Central & 4.9 & 24 \\
Northwest & 7.2 & 46 \\
North & 9.1 & 48 \\
Peten & 12.4 & 48 \\
\hline
\end{tabular}


Table B6: Access to fixed and cellular telephones (percentage of households)

\begin{tabular}{|c|c|c|c|c|c|}
\hline & \multicolumn{5}{|c|}{ Consumption quintile } \\
\hline & $1^{\text {st }}$ & $2^{\text {nd }}$ & $3^{\text {rd }}$ & $4^{\text {th }}$ & $5^{\text {th }}$ \\
\hline Fixed line only & .2 & 1 & 3 & 13 & 34 \\
\hline Cellular line only & .1 & 1 & 3 & 10 & 10 \\
\hline Both fixed and cellular lines & 0 & .1 & 0 & 1 & 24 \\
\hline Total & .3 & 2 & 6 & 24 & 68 \\
\hline
\end{tabular}

Table B7: Decomposition of coverage deficit

(percentage of households who lack coverage)

\begin{tabular}{l|c|c|c|c}
\hline & $\begin{array}{c}\text { Demand side } \\
\text { problem only }\end{array}$ & $\begin{array}{c}\text { Both supply side and } \\
\text { demand side } \\
\text { problem }\end{array}$ & $\begin{array}{c}\text { Supply side } \\
\text { problem only }\end{array}$ & Total \\
\hline Electricity & 37 & 7 & 56 & 100 \\
Water & 39 & 10 & 52 & 100 \\
Sewerage & 21 & 19 & 60 & 100 \\
Fixed telephone & 25 & 44 & 32 & 100 \\
Cellular telephone & 31 & 51 & 18 & 100 \\
\hline
\end{tabular}

Table B8: Expenditure on basic services

(percentage of consumption aggregate)

\begin{tabular}{|c|c|c|c|c|c|c|}
\hline & \multicolumn{5}{|c|}{ Consumption Quintiles } & \multirow[b]{2}{*}{ Total } \\
\hline & $1^{\text {st }}$ & $2^{\text {nd }}$ & $3^{\text {rd }}$ & $4^{\text {th }}$ & $5^{\text {th }}$ & \\
\hline Telecommunications & 0.12 & 0.53 & 0.65 & 1.79 & 3.69 & 1.4 \\
\hline Cooking and heating & 0.15 & 0.29 & 0.46 & 0.72 & 1.01 & 0.5 \\
\hline Lighting and appliances & 3.58 & 3.15 & 3.1 & 3.08 & 2.58 & 3.1 \\
\hline Water and sanitation & 7.87 & 6.86 & 5.62 & 4.19 & 2.21 & 5.3 \\
\hline Total & 11.72 & 10.83 & 9.83 & 9.78 & 9.49 & 10.3 \\
\hline
\end{tabular}

Table B9: Evolution of electricity tariffs following reform

(US\$ per kWh)

\begin{tabular}{ll|r|r|c|c}
\hline & & EEGSA & DEOCSA & DEORSA & Tarifa Social \\
\hline \multirow{2}{*}{1998} & March & 0.0835 & & & 0.0750 \\
& July & 0.0856 & & & 0.0750 \\
& November & 0.0856 & & & 0.0750 \\
\hline \multirow{2}{*}{1999} & March & 0.0856 & 0.0685 & 0.0685 & 0.0750 \\
& July & 0.1033 & 0.0698 & 0.0595 & 0.0750 \\
& November & 0.1063 & 0.0750 & 0.0740 & 0.0750 \\
\hline \multirow{2}{*}{2000} & March & 0.1063 & 0.0791 & 0.0772 & 0.0750 \\
& July & 0.1063 & 0.0870 & 0.0849 & 0.0750 \\
& November & 0.1415 & 0.0915 & 0.0892 & 0.0750 \\
\hline 2001 & March & 0.1519 & 0.0962 & 0.0940 & 0.0750 \\
\hline
\end{tabular}


Table B10: Cumulative density of electricity consumption

(cumulative percentage of households)

\begin{tabular}{c|c|c}
\hline $\begin{array}{c}\text { Electricity consumption } \\
\text { (kWh per month) }\end{array}$ & $\begin{array}{c}\text { Poor } \\
\text { customers }\end{array}$ & $\begin{array}{c}\text { Non-poor } \\
\text { customers }\end{array}$ \\
\hline 50 & 70 & 29 \\
100 & 91 & 54 \\
150 & 96 & 69 \\
200 & 99 & 79 \\
250 & 100 & 84 \\
300 & 100 & 90 \\
350 & 100 & 93 \\
400 & 100 & 95 \\
450 & 100 & 96 \\
500 & 100 & 97 \\
$<500$ & 100 & 100 \\
\hline
\end{tabular}

Table B11: Simulation of inclusion and exclusion errors and subsidy cost (various performance variables)

\begin{tabular}{c|c|c|c|c|c}
\hline $\begin{array}{c}\text { Electricity consumption } \\
\text { (kWh per month) }\end{array}$ & $\begin{array}{c}\text { Targeting errors } \\
\text { (percentage) }\end{array}$ & $\begin{array}{c}\text { Subsidy Cost } \\
\text { (US\$m pa) }\end{array}$ \\
& $\begin{array}{c}\text { Exclusion } \\
\text { (connected } \\
\text { poor) }\end{array}$ & $\begin{array}{c}\text { Exclusion } \\
\text { (all poor) }\end{array}$ & $\begin{array}{c}\text { Inclusion } \\
\text { (non- } \\
\text { poor) }\end{array}$ & $\begin{array}{c}\text { Leakage } \\
\text { (subsidy } \\
\text { cost) }\end{array}$ & \\
\hline 50 & 30 & 72 & 47 & 61 & 4.1 \\
100 & 8 & 64 & 56 & 75 & 13.2 \\
150 & 4 & 62 & 61 & 82 & 22.7 \\
200 & 2 & 61 & 63 & 85 & 32.0 \\
250 & 1 & 61 & 65 & 87 & 38.6 \\
300 & 0 & 61 & 66 & 89 & 48.9 \\
350 & 0 & 61 & 67 & 90 & 54.0 \\
400 & 0 & 60 & 67 & 91 & 58.7 \\
450 & 0 & 60 & 67 & 91 & 60.2 \\
500 & 0 & 60 & 67 & 92 & 62.9 \\
$<500$ & 30 & 72 & 47 & 61 & 4.1 \\
\hline
\end{tabular}


Table B12: Typical structure of water bills

\begin{tabular}{c|c|c|c|c|c|c|c}
\hline $\begin{array}{c}\mathrm{m}^{3} \text { per } \\
\text { month }\end{array}$ & \multicolumn{2}{|c|}{ EMPAGUA } & \multicolumn{2}{c}{ (US\$ per month) } \\
domestic & social & $\begin{array}{c}\text { Quetazal } \\
\text {-tenango }\end{array}$ & $\begin{array}{c}\text { San } \\
\text { Sebastian }\end{array}$ & $\begin{array}{c}\text { San } \\
\text { Martin }\end{array}$ & $\begin{array}{c}\text { San } \\
\text { Agustin }\end{array}$ & $\begin{array}{c}\text { San } \\
\text { Cristobal }\end{array}$ \\
\hline 5 & 0.66 & 1.32 & 1.81 & 0.33 & 0.33 & 0.39 & 0.66 \\
10 & 0.66 & 1.32 & 1.81 & 0.33 & 0.33 & 0.39 & 0.66 \\
15 & 0.66 & 1.32 & 1.81 & 0.33 & 0.33 & 0.39 & 0.66 \\
20 & 1.67 & 1.32 & 1.81 & 0.33 & 0.33 & 0.39 & 0.66 \\
25 & 2.02 & 1.32 & 2.11 & 0.33 & 0.33 & 0.39 & 0.66 \\
30 & 2.57 & 3.67 & 2.41 & 0.33 & 0.33 & 0.39 & 0.66 \\
35 & 3.12 & 5.32 & 3.62 & 0.33 & 0.33 & 0.39 & 0.66 \\
40 & 3.67 & 6.97 & 3.92 & 0.33 & 0.68 & 0.74 & 1.01 \\
45 & 4.22 & 8.62 & 4.52 & 0.33 & 1.03 & 1.09 & 1.36 \\
50 & 4.87 & 10.27 & 5.42 & 0.33 & 1.38 & 1.44 & 1.71 \\
55 & 6.17 & 11.92 & 6.62 & 0.33 & 1.73 & 1.79 & 2.06 \\
60 & 8.12 & 13.57 & 8.12 & 0.33 & 2.08 & 2.14 & 2.41 \\
65 & 10.72 & 15.22 & 9.92 & 0.33 & 2.43 & 2.49 & 2.76 \\
70 & 12.02 & 16.87 & 12.02 & 0.33 & 2.78 & 2.84 & 3.11 \\
75 & 13.32 & 18.52 & 14.42 & 0.33 & 3.13 & 3.19 & 3.46 \\
80 & 14.62 & 20.17 & 17.12 & 0.33 & 3.48 & 3.54 & 3.81 \\
85 & 15.92 & 21.82 & 20.12 & 0.33 & 3.83 & 3.89 & 4.16 \\
90 & 17.22 & 23.47 & 23.42 & 0.33 & 4.18 & 4.24 & 4.51 \\
95 & 18.52 & 25.12 & 27.02 & 0.33 & 4.53 & 4.59 & 4.86 \\
100 & 19.82 & 26.77 & 30.92 & 0.33 & 4.88 & 4.94 & 5.21 \\
\hline
\end{tabular}

Table B13 : Intra-household allocation of water and fuel wood collection tasks

(percentage of man-hours devoted yesterday by different groups)

\begin{tabular}{c|c|c}
\hline & Fuel wood & Water \\
\hline Men & 41 & 13 \\
Boys & 24 & 13 \\
Women & 24 & 50 \\
Girls & 11 & 24 \\
Total & 100 & 100 \\
\hline
\end{tabular}


C. Standard Summary Tables

Table C1: Availability, Take-up and Coverage

\begin{tabular}{|c|c|c|c|c|c|c|c|c|c|c|c|c|}
\hline \multirow[b]{3}{*}{ National } & \multicolumn{3}{|c|}{ Piped water ${ }^{1}$} & \multicolumn{3}{|c|}{ Electricity } & \multicolumn{3}{|c|}{ Propane } & \multicolumn{3}{|c|}{ Sewerage } \\
\hline & Availability & Take-up & Coverage & Availability & Take-up & Coverage & Availability & Take-up & Coverage & Availability & Take-up & Coverage \\
\hline & 0.81 & 0.85 & 0.69 & 0.83 & 0.88 & 0.73 & 0.74 & 0.61 & 0.45 & 0.44 & 0.68 & 0.30 \\
\hline Urban & 0.95 & 0.92 & 0.87 & 1.00 & 0.95 & 0.95 & 0.98 & 0.79 & 0.77 & 0.85 & 0.74 & 0.63 \\
\hline Rural & 0.70 & 0.76 & 0.53 & 0.70 & 0.81 & 0.57 & 0.55 & 0.37 & 0.20 & 0.13 & 0.39 & 0.05 \\
\hline \multicolumn{13}{|l|}{ Region } \\
\hline Metropolitan & 0.91 & 0.94 & 0.86 & 1.00 & 0.97 & 0.97 & 0.96 & 0.86 & 0.83 & 0.77 & 0.81 & 0.62 \\
\hline North & 0.65 & 0.74 & 0.48 & 0.43 & 0.75 & 0.32 & 0.44 & 0.35 & 0.15 & 0.18 & 0.43 & 0.08 \\
\hline Northeast & 0.85 & 0.77 & 0.65 & 0.65 & 0.91 & 0.59 & 0.86 & 0.53 & 0.46 & 0.29 & 0.61 & 0.18 \\
\hline Southeast & 0.82 & 0.79 & 0.65 & 0.78 & 0.87 & 0.68 & 0.71 & 0.45 & 0.32 & 0.27 & 0.57 & 0.15 \\
\hline Central & 0.82 & 0.83 & 0.68 & 0.95 & 0.88 & 0.84 & 0.87 & 0.57 & 0.50 & 0.49 & 0.60 & 0.29 \\
\hline Southwest & 0.77 & 0.84 & 0.65 & 0.89 & 0.86 & 0.77 & 0.72 & 0.50 & 0.36 & 0.42 & 0.61 & 0.26 \\
\hline Northwest & 0.85 & 0.78 & 0.66 & 0.74 & 0.76 & 0.56 & 0.30 & 0.46 & 0.14 & 0.23 & 0.58 & 0.13 \\
\hline Peten & 0.46 & 0.89 & 0.41 & 0.46 & 0.78 & 0.36 & 0.60 & 0.38 & 0.23 & 0.04 & 0.19 & 0.01 \\
\hline \multicolumn{13}{|l|}{ Poverty } \\
\hline Non-poor & 0.87 & 0.91 & 0.79 & 0.94 & 0.95 & 0.89 & 0.91 & 0.79 & 0.72 & 0.64 & 0.77 & 0.49 \\
\hline All poor & 0.74 & 0.75 & 0.56 & 0.70 & 0.77 & 0.54 & 0.53 & 0.25 & 0.13 & 0.21 & 0.36 & 0.08 \\
\hline Extreme poor & 0.71 & 0.67 & 0.48 & 0.53 & 0.58 & 0.31 & 0.33 & 0.04 & 0.01 & 0.09 & 0.17 & 0.02 \\
\hline \multicolumn{13}{|l|}{ Quintile } \\
\hline 1 (poorest) & 0.71 & 0.71 & 0.50 & 0.59 & 0.66 & 0.39 & 0.38 & 0.06 & 0.02 & 0.11 & 0.20 & 0.02 \\
\hline 2.00 & 0.78 & 0.79 & 0.62 & 0.77 & 0.82 & 0.63 & 0.61 & 0.29 & 0.18 & 0.27 & 0.38 & 0.10 \\
\hline 3.00 & 0.77 & 0.82 & 0.63 & 0.86 & 0.90 & 0.77 & 0.80 & 0.55 & 0.44 & 0.38 & 0.56 & 0.21 \\
\hline 4.00 & 0.85 & 0.90 & 0.77 & 0.95 & 0.95 & 0.90 & 0.92 & 0.80 & 0.74 & 0.60 & 0.69 & 0.41 \\
\hline 5 (richest) & 0.96 & 0.97 & 0.93 & 0.97 & 0.98 & 0.95 & 0.98 & 0.90 & 0.88 & 0.84 & 0.90 & 0.76 \\
\hline \multicolumn{13}{|l|}{ Ethnicity } \\
\hline Non-indigenous & 0.83 & 0.88 & 0.73 & 0.88 & 0.92 & 0.81 & 0.85 & 0.69 & 0.59 & 0.54 & 0.74 & 0.40 \\
\hline Indigenous & 0.78 & 0.79 & 0.62 & 0.75 & 0.81 & 0.61 & 0.56 & 0.42 & 0.24 & 0.28 & 0.51 & 0.14 \\
\hline Quiche & 0.89 & 0.82 & 0.73 & 0.91 & 0.88 & 0.80 & 0.73 & 0.52 & 0.38 & 0.45 & 0.54 & 0.24 \\
\hline Q'eqchi & 0.47 & 0.69 & 0.32 & 0.35 & 0.76 & 0.27 & 0.45 & 0.30 & 0.14 & 0.11 & 0.42 & 0.05 \\
\hline Kaqchiqel & 0.81 & 0.82 & 0.66 & 0.98 & 0.87 & 0.85 & 0.80 & 0.46 & 0.37 & 0.38 & 0.50 & 0.19 \\
\hline Mam & 0.84 & 0.80 & 0.67 & 0.72 & 0.70 & 0.50 & 0.32 & 0.28 & 0.09 & 0.17 & 0.45 & 0.08 \\
\hline Other ind & 0.79 & 0.76 & 0.60 & 0.64 & 0.76 & 0.49 & 0.39 & 0.34 & 0.13 & 0.19 & 0.52 & 0.10 \\
\hline
\end{tabular}

Source: World Bank calculations using the ENCOVI 2000, Instituto Nacional de Estadística - Guatemala 
Table C1: Availability, Take-up and Coverage (continued)

\begin{tabular}{|c|c|c|c|c|c|c|c|c|c|}
\hline \multirow[b]{3}{*}{ National } & \multicolumn{3}{|c|}{ Sanitation } & \multicolumn{3}{|c|}{ Fixed phone } & \multicolumn{3}{|c|}{ Cell phone } \\
\hline & Availability & Take-up & Coverage & Availability & Take-up & Coverage & Availability & Take-up & Coverage \\
\hline & 0.98 & 0.88 & 0.86 & 0.36 & 0.42 & 0.15 & 0.38 & 0.25 & 0.10 \\
\hline Urban & 1.00 & 0.98 & 0.98 & 0.68 & 0.46 & 0.31 & 0.65 & 0.29 & 0.19 \\
\hline Rural & 0.97 & 0.81 & 0.79 & 0.11 & 0.24 & 0.03 & 0.18 & 0.16 & 0.03 \\
\hline \multicolumn{10}{|l|}{ Region } \\
\hline Metropolitan & 1.00 & 0.97 & 0.97 & 0.66 & 0.53 & 0.35 & 0.81 & 0.32 & 0.26 \\
\hline North & 1.00 & 0.91 & 0.91 & 0.13 & 0.26 & 0.03 & 0.09 & 0.14 & 0.01 \\
\hline Northeast & 0.96 & 0.80 & 0.77 & 0.34 & 0.36 & 0.12 & 0.48 & 0.18 & 0.09 \\
\hline Southeast & 0.96 & 0.75 & 0.72 & 0.19 & 0.34 & 0.06 & 0.23 & 0.15 & 0.03 \\
\hline Central & 0.99 & 0.92 & 0.91 & 0.36 & 0.29 & 0.10 & 0.29 & 0.19 & 0.06 \\
\hline Southwest & 0.99 & 0.88 & 0.87 & 0.32 & 0.33 & 0.11 & 0.24 & 0.19 & 0.05 \\
\hline Northwest & 0.95 & 0.84 & 0.80 & 0.12 & 0.37 & 0.04 & 0.11 & 0.18 & 0.02 \\
\hline Peten & 0.93 & 0.74 & 0.69 & 0.15 & 0.37 & 0.06 & 0.15 & 0.21 & 0.03 \\
\hline \multicolumn{10}{|l|}{ Poverty } \\
\hline Non-poor & 0.99 & 0.95 & 0.94 & 0.57 & 0.48 & 0.27 & 0.57 & 0.30 & 0.17 \\
\hline All poor & 0.97 & 0.81 & 0.79 & 0.11 & 0.06 & 0.01 & 0.15 & 0.06 & 0.01 \\
\hline Extreme poor & 0.95 & 0.75 & 0.71 & 0.03 & 0.14 & 0.00 & 0.07 & 0.00 & 0.00 \\
\hline \multicolumn{10}{|l|}{ Quintile } \\
\hline 1 (poorest) & 0.96 & 0.77 & 0.74 & 0.04 & 0.06 & 0.00 & 0.08 & 0.01 & 0.00 \\
\hline 2.00 & 0.98 & 0.82 & 0.80 & 0.14 & 0.05 & 0.01 & 0.18 & 0.06 & 0.01 \\
\hline 3.00 & 0.99 & 0.90 & 0.89 & 0.27 & 0.11 & 0.03 & 0.34 & 0.08 & 0.03 \\
\hline 4.00 & 1.00 & 0.95 & 0.95 & 0.50 & 0.28 & 0.14 & 0.50 & 0.21 & 0.11 \\
\hline 5 (richest) & 1.00 & 0.98 & 0.98 & 0.84 & 0.69 & 0.58 & 0.81 & 0.42 & 0.34 \\
\hline \multicolumn{10}{|l|}{ Ethnicity } \\
\hline Non-indigenous & 0.99 & 0.89 & 0.88 & 0.47 & 0.47 & 0.22 & 0.49 & 0.29 & 0.14 \\
\hline Indigenous & 0.97 & 0.87 & 0.84 & 0.19 & 0.22 & 0.04 & 0.21 & 0.13 & 0.03 \\
\hline Quiche & 0.98 & 0.85 & 0.83 & 0.36 & 0.18 & 0.06 & 0.31 & 0.11 & 0.03 \\
\hline Q'eqchi & 1.00 & 0.88 & 0.88 & 0.10 & 0.14 & 0.01 & 0.19 & 0.08 & 0.02 \\
\hline Kaqchiqel & 1.00 & 0.93 & 0.93 & 0.26 & 0.25 & 0.07 & 0.36 & 0.11 & 0.04 \\
\hline Mam & 0.97 & 0.87 & 0.84 & 0.06 & 0.25 & 0.02 & 0.05 & 0.30 & 0.02 \\
\hline Other ind & 0.91 & 0.83 & 0.76 & 0.10 & 0.30 & 0.03 & 0.09 & 0.34 & 0.03 \\
\hline
\end{tabular}

Source: World Bank calculations using the ENCOVI 2000, Instituto Nacional de Estadística - Guatemala 
Table C2: Coverage gap

\begin{tabular}{|c|c|c|c|c|c|c|c|c|c|c|c|c|c|c|}
\hline \\
\hline & \multicolumn{7}{|c|}{ Number of households without access to } & \multicolumn{7}{|c|}{ Proportion of total gap in each group } \\
\hline & Piped water ${ }^{1}$ & Electricity & Propane & Sewerage $^{2}$ & Sanitation $^{3}$ & Fixed Phone & Cellular phone & Piped water ${ }^{1}$ & Electricity & Propane & Sewerage $^{2}$ & Sanitation $^{3}$ & Fixed Phone & Cellular phone \\
\hline National & 683,111 & 584,141 & $1,190,928$ & $1,521,984$ & 286,980 & $1,747,331$ & $1,967,640$ & & & & & & & \\
\hline Urban & 111,843 & 44,468 & 206,408 & 346,951 & 23,478 & 574,821 & 767,760 & 0.16 & 0.08 & 0.17 & 0.23 & 0.08 & 0.33 & 0.39 \\
\hline Rural & 571,268 & 539,673 & 984,520 & $1,175,033$ & 263,502 & $1,172,510$ & $1,199,879$ & 0.84 & 0.92 & 0.83 & 0.77 & 0.92 & 0.67 & 0.61 \\
\hline \multicolumn{15}{|l|}{ Region } \\
\hline Metropolitan & 77,394 & 18,440 & 93,685 & 205,153 & 15,197 & 296,145 & 402,422 & 0.11 & 0.03 & 0.08 & 0.13 & 0.05 & 0.17 & 0.20 \\
\hline North & 83,226 & 107,895 & 134,736 & 146,897 & 14,276 & 152,605 & 157,320 & 0.12 & 0.18 & 0.11 & 0.10 & 0.05 & 0.09 & 0.08 \\
\hline Northeast & 66,432 & 79,395 & 104,240 & 158,207 & 45,275 & 156,070 & 176,092 & 0.10 & 0.14 & 0.09 & 0.10 & 0.16 & 0.09 & 0.09 \\
\hline Southeast & 65,489 & 59,547 & 127,687 & 159,727 & 54,029 & 171,986 & 181,781 & 0.10 & 0.10 & 0.11 & 0.10 & 0.19 & 0.10 & 0.09 \\
\hline Central & 75,934 & 39,508 & 122,526 & 171,028 & 20,684 & 208,283 & 228,082 & 0.11 & 0.07 & 0.10 & 0.11 & 0.07 & 0.12 & 0.12 \\
\hline Southwest & 193,415 & 130,057 & 347,995 & 404,460 & 68,189 & 471,506 & 519,875 & 0.28 & 0.22 & 0.29 & 0.27 & 0.24 & 0.27 & 0.26 \\
\hline Northwest & 82,838 & 107,566 & 209,848 & 212,135 & 49,090 & 230,098 & 239,224 & 0.12 & 0.18 & 0.18 & 0.14 & 0.17 & 0.13 & 0.12 \\
\hline Peten & 38,383 & 41,734 & 50,211 & 64,377 & 20,241 & 60,640 & 62,844 & 0.06 & 0.07 & 0.04 & 0.04 & 0.07 & 0.03 & 0.03 \\
\hline \multicolumn{15}{|l|}{ Poverty } \\
\hline Non-poor & 240,705 & 124,009 & 324,404 & 598,060 & 68,169 & 762,763 & 976,921 & 0.35 & 0.21 & 0.27 & 0.39 & 0.24 & 0.44 & 0.50 \\
\hline All poor & 442,406 & 460,132 & 866,525 & 923,924 & 218,810 & 984,568 & 990,719 & 0.65 & 0.79 & 0.73 & 0.61 & 0.76 & 0.56 & 0.50 \\
\hline Extreme poor & 123,338 & 163,615 & 232,740 & 232,105 & 66,678 & 234,580 & 235,678 & 0.18 & 0.28 & 0.20 & 0.15 & 0.23 & 0.13 & 0.12 \\
\hline \multicolumn{15}{|l|}{ Quintile } \\
\hline 1 (poorest) & 219,573 & 266,303 & 426,486 & 427,226 & 116,259 & 435,668 & 436,766 & 0.32 & 0.46 & 0.36 & 0.28 & 0.41 & 0.25 & 0.22 \\
\hline 2 & 161,818 & 154,008 & 349,745 & 381,385 & 82,959 & 417,626 & 420,242 & 0.24 & 0.26 & 0.29 & 0.25 & 0.29 & 0.24 & 0.21 \\
\hline 3 & 163,691 & 98,389 & 248,703 & 350,730 & 51,775 & 419,808 & 433,129 & 0.24 & 0.17 & 0.21 & 0.23 & 0.18 & 0.24 & 0.22 \\
\hline 4 & 104,376 & 44,496 & 115,959 & 254,855 & 25,993 & 333,828 & 391,852 & 0.15 & 0.08 & 0.10 & 0.17 & 0.09 & 0.19 & 0.20 \\
\hline 5 (richest) & 33,653 & 20,945 & 50,035 & 107,789 & 9,993 & 140,401 & 285,650 & 0.05 & 0.04 & 0.04 & 0.07 & 0.03 & 0.08 & 0.15 \\
\hline \multicolumn{15}{|l|}{ Ethnicity } \\
\hline Non-indigenous & 359,148 & 255,024 & 543,016 & 794,063 & 158,100 & 952,527 & $1,143,277$ & 0.53 & 0.44 & 0.46 & 0.52 & 0.55 & 0.55 & 0.58 \\
\hline Indigenous & 323,963 & 329,117 & 647,913 & 727,921 & 128,879 & 794,804 & 824,363 & 0.47 & 0.56 & 0.54 & 0.48 & 0.45 & 0.45 & 0.42 \\
\hline Quiche & 51,165 & 39,063 & 119,419 & 145,941 & 32,437 & 175,736 & 186,896 & 0.07 & 0.07 & 0.10 & 0.10 & 0.11 & 0.10 & 0.09 \\
\hline Q'eqchi & 84,929 & 92,404 & 108,948 & 120,188 & 15,017 & 122,897 & 124,301 & 0.12 & 0.16 & 0.09 & 0.08 & 0.05 & 0.07 & 0.06 \\
\hline Kaqchiqel & 65,097 & 29,162 & 120,929 & 154,483 & 13,444 & 173,358 & 183,755 & 0.10 & 0.05 & 0.10 & 0.10 & 0.05 & 0.10 & 0.09 \\
\hline Mam & 52,676 & 78,102 & 144,693 & 147,139 & 25,416 & 154,325 & 156,707 & 0.08 & 0.13 & 0.12 & 0.10 & 0.09 & 0.09 & 0.08 \\
\hline Other ind & 70,097 & 90,386 & 153,924 & 160,170 & 42,565 & 168,488 & 172,704 & 0.10 & 0.15 & 0.13 & 0.11 & 0.15 & 0.10 & 0.09 \\
\hline
\end{tabular}


Table C3: Quality of services

\begin{tabular}{|c|c|c|c|c|c|c|c|}
\hline & \multicolumn{3}{|c|}{ Among those with electricity } & \multicolumn{4}{|c|}{ Among those with piped water ${ }^{1}$} \\
\hline & \# of blackouts & $\begin{array}{c}\text { days without } \\
\text { Service }^{2}\end{array}$ & \begin{tabular}{|c|} 
hours/day \\
with service $^{3}$ \\
\end{tabular} & $\begin{array}{c}\text { days without } \\
\text { Service }^{2}\end{array}$ & \begin{tabular}{|c|} 
hours/day \\
with service $^{3}$ \\
\end{tabular} & $\begin{array}{c}\text { proportion who } \\
\text { treat water }\end{array}$ & $\begin{array}{l}\text { proportion who } \\
\text { buy bottled water }\end{array}$ \\
\hline National & 2.90 & 0.69 & 23.4 & 3.58 & 16.7 & 0.61 & 0.22 \\
\hline Urban & 2.20 & 0.34 & 23.5 & 3.54 & 15.2 & 0.57 & 0.35 \\
\hline Rural & 3.79 & 1.14 & 23.4 & 3.62 & 18.5 & 0.66 & 0.05 \\
\hline \multicolumn{8}{|l|}{ Region } \\
\hline Metropolitan & 0.75 & 0.22 & 23.8 & 3.76 & 13.1 & 0.47 & 0.43 \\
\hline North & 3.36 & 0.56 & 23.4 & 3.98 & 20.1 & 0.64 & 0.07 \\
\hline Northeast & 3.75 & 0.87 & 23.3 & 3.29 & 17.4 & 0.50 & 0.15 \\
\hline Southeast & 4.25 & 1.30 & 22.5 & 4.66 & 17.8 & 0.49 & 0.06 \\
\hline Central & 2.30 & 0.51 & 23.5 & 4.67 & 15.1 & 0.60 & 0.18 \\
\hline Southwest & 3.65 & 0.90 & 23.4 & 2.76 & 19.1 & 0.83 & 0.12 \\
\hline Northwest & 7.42 & 1.52 & 23.1 & 2.91 & 20.6 & 0.78 & 0.06 \\
\hline Peten & 4.06 & 0.34 & 23.4 & 3.82 & 14.6 & 0.46 & 0.18 \\
\hline \multicolumn{8}{|l|}{ Poverty } \\
\hline Non-poor & 2.44 & 0.51 & 23.5 & 3.39 & 15.6 & 0.59 & 0.33 \\
\hline All poor & 3.79 & 1.03 & 23.4 & 3.89 & 18.5 & 0.65 & 0.03 \\
\hline Extreme poor & 4.89 & 1.30 & 23.3 & $*$ & $*$ & 0.64 & 0.03 \\
\hline \multicolumn{8}{|l|}{ Quintile } \\
\hline 1 (poorest) & 4.56 & 1.19 & 23.3 & 3.79 & 19.8 & 0.64 & 0.02 \\
\hline 2 & 3.64 & 1.06 & 23.3 & 3.91 & 17.8 & 0.66 & 0.03 \\
\hline 3 & 2.87 & 0.74 & 23.5 & 4.33 & 16.2 & 0.69 & 0.10 \\
\hline 4 & 2.52 & 0.59 & 23.4 & 3.76 & 15.7 & 0.64 & 0.24 \\
\hline 5 (richest) & 2.09 & 0.29 & 23.5 & 2.56 & 15.3 & 0.50 & 0.50 \\
\hline \multicolumn{8}{|l|}{ Ethnicity } \\
\hline Non-indigenous & 2.48 & 0.60 & 23.4 & 3.51 & 15.9 & 0.55 & 0.28 \\
\hline Indigenous & 3.75 & 0.88 & 23.4 & 3.71 & 18.1 & 0.74 & 0.09 \\
\hline Quiche & 3.38 & 0.60 & 23.4 & 3.06 & 19.2 & 0.78 & 0.13 \\
\hline Q'eqchi & 2.44 & 1.00 & 23.3 & 5.41 & 18.7 & 0.76 & 0.06 \\
\hline Kaqchiqel & 2.33 & 0.62 & 23.5 & 5.67 & 13.2 & 0.60 & 0.11 \\
\hline Mam & 4.28 & 1.18 & 23.3 & 2.95 & 20.0 & 0.82 & 0.04 \\
\hline Other ind & 7.03 & 1.50 & 23.4 & 2.37 & 20.1 & 0.75 & 0.06 \\
\hline
\end{tabular}

*: No observations available. 1: Piped water in dwelling or field. 2: Consecutive days without service in previous month. 3: Consecutive hours-per-day with service in previous month. Source: World Bank calculations using the ENCOVI 2000, Instituto Nacional de Estadística - Guatemala 
Table C4: Consumption

\begin{tabular}{|c|c|c|c|c|c|c|c|c|c|c|c|c|c|c|c|}
\hline & \multicolumn{5}{|c|}{ Energy for lighting and appliances } & \multicolumn{5}{|c|}{ Energy for cooking } & \multicolumn{5}{|c|}{ Energy for cooking, lighting and appliances } \\
\hline & Gross kwh & Net kwh & Price of gkw & Price of nkw & Efficiency & Gross kwh & Net kwh & Price of gkw & Price of nkw & Efficiency & Gross kwh & Net kwh & Price of gkw & Price of nkw & Efficiency \\
\hline National & 69.1 & 61.6 & 3.15 & 33.5 & 9.9 & 1,268 & 236 & 0.21 & 0.51 & 4.51 & 1,341 & 298 & 8.0 & 1.69 & 5.67 \\
\hline Urban & 108.5 & 105.0 & 2.30 & 27.0 & 4.0 & 759 & 194 & 0.34 & 0.59 & 2.88 & 870 & 300 & 4.4 & 1.50 & 3.02 \\
\hline Rural & 39.1 & 28.6 & 3.79 & 38.4 & 14.3 & 1,656 & 268 & 0.10 & 0.45 & 5.89 & 1,699 & 297 & 10.7 & 1.84 & 7.70 \\
\hline \multicolumn{16}{|l|}{ Region } \\
\hline Metropolitan & 130.3 & 128.5 & 2.16 & 24.2 & 3.8 & 342 & 138 & 0.40 & 0.67 & 0.16 & 36 & 267 & 2.2 & 1.26 & 2.14 \\
\hline North & 39.7 & 19.7 & 2.94 & 48.7 & 23.7 & 1,176 & 190 & 0.12 & 0.50 & 0.10 & 105 & 210 & 8.4 & 1.39 & 11.07 \\
\hline Northeast & 50.5 & 42.1 & 4.50 & 43.3 & 13.0 & 1,500 & 268 & 0.19 & 0.49 & 0.28 & 224 & 312 & 9.8 & 1.96 & 5.65 \\
\hline Southeast & 45.1 & 37.9 & 3.65 & 50.0 & 12.9 & 1,817 & 302 & 0.12 & 0.37 & 0.15 & 213 & 341 & 11.3 & 2.05 & 7.77 \\
\hline Central & 68.3 & 60.4 & 2.82 & 27.5 & 6.2 & 1,264 & 238 & 0.19 & 0.50 & 0.15 & 95 & 301 & 8.0 & 1.75 & 5.10 \\
\hline Southwest & 50.7 & 43.7 & 3.14 & 27.5 & 8.8 & 1,569 & 271 & 0.13 & 0.44 & 0.13 & 133 & 315 & 10.0 & 1.88 & 5.69 \\
\hline Northwest & 31.9 & 22.8 & 4.35 & 39.3 & 12.6 & 1,812 & 286 & 0.10 & 0.47 & 0.09 & 177 & 308 & 10.2 & 1.71 & 7.80 \\
\hline Peten & 51.2 & 31.2 & 3.25 & 46.4 & 20.3 & 2,408 & 380 & 0.11 & 0.36 & 0.15 & 292 & 411 & 14.3 & 2.36 & 9.93 \\
\hline \multicolumn{16}{|l|}{ Poverty } \\
\hline Non-poor & 99.1 & 94.5 & 2.60 & 22.7 & 4.7 & 973 & 220 & 0.30 & 0.56 & 3.29 & 1,076 & 315 & 5.4 & 1.56 & 3.49 \\
\hline All poor & 33.7 & 22.8 & 3.80 & 46.1 & 15.9 & 1,616 & 255 & 0.09 & 0.44 & 6.10 & 1,653 & 278 & 11.0 & 1.85 & 8.24 \\
\hline Extreme poor & 26.2 & 11.9 & 3.95 & 55.6 & 24.5 & 1,460 & 221 & 0.06 & 0.40 & 6.57 & 1,486 & 233 & 11.6 & 1.79 & 10.59 \\
\hline \multicolumn{16}{|l|}{ Quintile } \\
\hline 1 (poorest) & 27.6 & 13.9 & 3.73 & 51.3 & 20.9 & 1,548 & 235 & 0.07 & 0.41 & 6.52 & 1,577 & 249 & 11.7 & 1.84 & 9.86 \\
\hline 2 & 35.5 & 26.2 & 3.77 & 40.7 & 12.1 & 1,695 & 271 & 0.10 & 0.45 & 5.96 & 1,736 & 298 & 10.9 & 1.88 & 7.27 \\
\hline 3 & 53.0 & 46.3 & 3.31 & 36.0 & 9.1 & 1,472 & 260 & 0.17 & 0.50 & 4.91 & 1,527 & 306 & 8.6 & 1.78 & 5.44 \\
\hline 4 & 84.1 & 79.3 & 2.77 & 25.3 & 4.5 & 1,133 & 237 & 0.26 & 0.55 & 3.55 & 1,220 & 317 & 5.8 & 1.60 & 3.63 \\
\hline 5 (richest) & 145.5 & 142.4 & 2.16 & 13.8 & 2.5 & 493 & 176 & 0.42 & 0.63 & 2.05 & 641 & 320 & 2.8 & 1.36 & 2.17 \\
\hline \multicolumn{16}{|l|}{ Ethnicity } \\
\hline Non-indigenous & 86.0 & 80.3 & 3.17 & 31.2 & 7.4 & 1,040 & 216 & 0.27 & 0.54 & 3.73 & 1,130 & 298 & 6.5 & 1.62 & 4.59 \\
\hline Indigenous & 42.6 & 32.2 & 3.13 & 37.1 & 13.8 & 1,626 & 266 & 0.12 & 0.47 & 5.75 & 1,671 & 298 & 10.3 & 1.81 & 7.37 \\
\hline Quiche & 44.9 & 40.2 & 3.31 & 28.8 & 8.9 & 1,187 & 213 & 0.14 & 0.53 & 5.34 & 1,232 & 254 & 7.7 & 1.55 & 5.53 \\
\hline Q'eqchi & 41.7 & 19.6 & 2.29 & 35.0 & 22.3 & 1,446 & 229 & 0.11 & 0.50 & 6.01 & 1,488 & 248 & 9.5 & 1.54 & 9.10 \\
\hline Kaqchiqel & 59.6 & 55.3 & 2.39 & 41.9 & 7.5 & 1,724 & 295 & 0.15 & 0.49 & 5.27 & 1,792 & 352 & 10.0 & 1.94 & 5.53 \\
\hline Mam & 29.6 & 16.9 & 2.66 & 27.3 & 17.2 & 1,878 & 290 & 0.07 & 0.38 & 6.35 & 1,907 & 307 & 13.7 & 2.19 & 7.83 \\
\hline Other ind & 33.9 & 21.5 & 4.78 & 51.7 & 16.6 & 1,902 & 297 & 0.10 & 0.46 & 6.03 & 1,936 & 318 & 10.9 & 1.81 & 9.72 \\
\hline
\end{tabular}

Source: World Bank calculations using the ENCOVI 2000, Instituto Nacional de Estadística - Guatemala 
Table C5: Expenditure

\begin{tabular}{|c|c|c|c|c|c|c|c|c|}
\hline \multicolumn{9}{|c|}{ 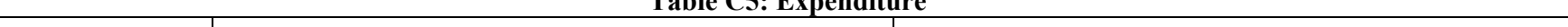 } \\
\hline & \multicolumn{4}{|c|}{ In Quetzales per month } & \multicolumn{4}{|c|}{ As a percentage of consumption expenditure } \\
\hline & Piped water ${ }^{1}$ & $\begin{array}{c}\text { Energy } \\
\text { for cooking } \\
\end{array}$ & $\begin{array}{c}\text { Energy for } \\
\text { lighting and applianes }\end{array}$ & Telecom. & Piped water ${ }^{1}$ & \begin{tabular}{|c|} 
Energy \\
for cooking
\end{tabular} & \begin{tabular}{|c|} 
Energy for \\
lighting and applianes \\
\end{tabular} & Telecom. \\
\hline National & 11 & 74 & 96 & 69 & $0.33 \%$ & $3.09 \%$ & $5.35 \%$ & $1.36 \%$ \\
\hline Urban & 20 & 109 & 98 & 130 & $0.52 \%$ & $3.08 \%$ & $3.81 \%$ & $2.20 \%$ \\
\hline Rural & 3 & 48 & 94 & 22 & $0.18 \%$ & $3.10 \%$ & $6.53 \%$ & $0.72 \%$ \\
\hline \multicolumn{9}{|l|}{ Region } \\
\hline Metropolitan & 26 & 133 & 92 & 171 & $0.58 \%$ & $3.13 \%$ & $2.99 \%$ & $2.48 \%$ \\
\hline North & 2 & 45 & 85 & 12 & $0.11 \%$ & $3.50 \%$ & $6.89 \%$ & $0.29 \%$ \\
\hline Northeast & 6 & 57 & 88 & 48 & $0.26 \%$ & $2.85 \%$ & $4.92 \%$ & $1.42 \%$ \\
\hline Southeast & 5 & 54 & 88 & 27 & $0.26 \%$ & $3.22 \%$ & $5.92 \%$ & $0.90 \%$ \\
\hline Central & 12 & 70 & 98 & 36 & $0.48 \%$ & $3.39 \%$ & $5.43 \%$ & $0.89 \%$ \\
\hline Southwest & 5 & 55 & 103 & 39 & $0.23 \%$ & $2.91 \%$ & $6.17 \%$ & $1.06 \%$ \\
\hline Northwest & 2 & 43 & 105 & 34 & $0.09 \%$ & $2.98 \%$ & $7.66 \%$ & $1.17 \%$ \\
\hline Peten & 6 & 56 & 91 & 34 & $0.25 \%$ & $2.92 \%$ & $5.17 \%$ & $0.92 \%$ \\
\hline \multicolumn{9}{|l|}{ Poverty } \\
\hline Non-poor & 17 & 102 & 101 & 120 & $0.44 \%$ & $2.91 \%$ & $3.75 \%$ & $2.18 \%$ \\
\hline All poor & 3 & 42 & 90 & 8 & $0.20 \%$ & $3.31 \%$ & $7.24 \%$ & $0.40 \%$ \\
\hline Extreme poor & 1 & 35 & 74 & 1 & $0.13 \%$ & $3.87 \%$ & $8.54 \%$ & $0.07 \%$ \\
\hline \multicolumn{9}{|l|}{ Quintile } \\
\hline 1 (poorest) & 1 & 36 & 78 & 2 & $0.14 \%$ & $3.57 \%$ & $7.86 \%$ & $0.12 \%$ \\
\hline 2 & 4 & 44 & 95 & 11 & $0.23 \%$ & $3.16 \%$ & $6.87 \%$ & $0.58 \%$ \\
\hline 3 & 6 & 59 & 103 & 17 & $0.30 \%$ & $3.08 \%$ & $5.63 \%$ & $0.64 \%$ \\
\hline 4 & 12 & 81 & 103 & 60 & $0.41 \%$ & $3.08 \%$ & $4.20 \%$ & $1.79 \%$ \\
\hline 5 (richest) & 31 & 151 & 99 & 256 & $0.56 \%$ & $2.58 \%$ & $2.22 \%$ & $3.68 \%$ \\
\hline \multicolumn{9}{|l|}{ Ethnicity } \\
\hline Non-indigenous & 15 & 90 & 93 & 99 & $0.40 \%$ & $2.99 \%$ & $4.13 \%$ & $1.76 \%$ \\
\hline Indigenous & 4 & 49 & 101 & 21 & $0.21 \%$ & $3.26 \%$ & $7.27 \%$ & $0.73 \%$ \\
\hline Quiche & 7 & 51 & 103 & 23 & $0.34 \%$ & $2.87 \%$ & $6.49 \%$ & $0.72 \%$ \\
\hline Q'eqchi & 2 & 48 & 88 & 8 & $0.13 \%$ & $3.81 \%$ & $7.33 \%$ & $0.26 \%$ \\
\hline Kaqchiqel & 6 & 64 & 115 & 19 & $0.29 \%$ & $3.58 \%$ & $7.35 \%$ & $0.69 \%$ \\
\hline Mam & 2 & 36 & 92 & 19 & $0.15 \%$ & $3.14 \%$ & $8.09 \%$ & $0.91 \%$ \\
\hline Other ind & 2 & 44 & 100 & 31 & $0.11 \%$ & $3.04 \%$ & $7.26 \%$ & $0.98 \%$ \\
\hline
\end{tabular}

Source: World Bank calculations using the ENCOVI 2000, Instituto Nacional de Estadística - Guatemala 
Table C6: Cost recovery

\begin{tabular}{|c|c|c|c|c|c|c|}
\hline \\
\hline & \multicolumn{3}{|c|}{ Piped water ${ }^{1}$} & \multicolumn{3}{|c|}{ Electricity } \\
\hline & \multirow{2}{*}{$\begin{array}{l}\text { Proportion of } \\
\text { hh with service } \\
\text { who do not pay }\end{array}$} & \multicolumn{2}{|c|}{ Monthly Quetzales paid } & \multirow{2}{*}{$\begin{array}{l}\text { Proportion of } \\
\text { hh with service } \\
\text { who do not pay }\end{array}$} & \multicolumn{2}{|c|}{ Monthly Quetzales paid } \\
\hline & & Everyone & $\begin{array}{c}\text { Only those who } \\
\text { pay an amount }>0\end{array}$ & & Everyone & $\begin{array}{l}\text { Only those who } \\
\text { pay an amount }>0\end{array}$ \\
\hline National & 0.30 & 11 & 22 & 0.08 & 60 & 89 \\
\hline Urban & 0.22 & 20 & 29 & 0.07 & 103 & 118 \\
\hline Rural & 0.40 & 3 & 11 & 0.09 & 26 & 51 \\
\hline \multicolumn{7}{|l|}{ Region } \\
\hline Metropolitan & 0.24 & 26 & 40 & 0.09 & 132 & 151 \\
\hline North & 0.24 & 2 & 6 & 0.10 & 18 & 61 \\
\hline Northeast & 0.28 & 6 & 12 & 0.12 & 39 & 76 \\
\hline Southeast & 0.27 & 5 & 9 & 0.12 & 34 & 57 \\
\hline Central & 0.28 & 12 & 24 & 0.07 & 55 & 71 \\
\hline Southwest & 0.36 & 5 & 13 & 0.06 & 38 & 54 \\
\hline Northwest & 0.49 & 2 & 5 & 0.07 & 21 & 41 \\
\hline Peten & 0.14 & 6 & 17 & 0.06 & 30 & 91 \\
\hline \multicolumn{7}{|l|}{ Poverty } \\
\hline Non-poor & 0.25 & 17 & 29 & 0.07 & 93 & 112 \\
\hline All poor & 0.39 & 3 & 8 & 0.10 & 21 & 42 \\
\hline Extreme poor & 0.46 & 1 & 5 & 0.13 & 11 & 41 \\
\hline \multicolumn{7}{|l|}{ Quintile } \\
\hline 1 (poorest) & 0.46 & 1 & 5 & 0.10 & 13 & 37 \\
\hline 2 & 0.35 & 4 & 9 & 0.09 & 24 & 41 \\
\hline 3 & 0.36 & 6 & 15 & 0.10 & 41 & 59 \\
\hline 4 & 0.28 & 12 & 21 & 0.06 & 68 & 81 \\
\hline 5 (richest) & 0.17 & 31 & 40 & 0.06 & 152 & 173 \\
\hline \multicolumn{7}{|l|}{ Ethnicity } \\
\hline Non-indigenous & 0.26 & 15 & 28 & 0.09 & 79 & 107 \\
\hline Indigenous & 0.38 & 4 & 11 & 0.07 & 29 & 52 \\
\hline Quiche & 0.34 & 7 & 15 & 0.08 & 39 & 53 \\
\hline Q'eqchi & 0.21 & 2 & 9 & 0.09 & 16 & 67 \\
\hline Kaqchiqel & 0.30 & 6 & 12 & 0.04 & 50 & 62 \\
\hline Mam & 0.56 & 2 & 8 & 0.04 & 16 & 32 \\
\hline Other ind & 0.39 & 2 & 6 & 0.09 & 19 & 44 \\
\hline
\end{tabular}

Source: World Bank calculations using the ENCOVI 2000, Instituto Nacional de Estadística - Guatemala 
Table C7: Social tariff

\begin{tabular}{|c|c|c|c|c|c|c|c|c|c|c|}
\hline \\
\hline & \multirow{2}{*}{$\begin{array}{l}\text { Connection rate } \\
\text { (proporiton of hh) }\end{array}$} & \multirow{2}{*}{$\begin{array}{l}\text { Consumption }^{1} \\
\text { (kwh/month) }\end{array}$} & \multicolumn{2}{|c|}{ Exp. in Quetzales } & \multicolumn{2}{|c|}{ Exp. as prop. of consumption } & \multirow{2}{*}{$\begin{array}{c}\text { Avg. subsidy } \\
\text { (Quetzales) }\end{array}$} & \multirow{2}{*}{$\begin{array}{l}\text { Number of hh } \\
\text { beneficiaries }\end{array}$} & \multirow{2}{*}{$\begin{array}{c}\text { Total subsidy } \\
\text { (US\$) }\end{array}$} & \multirow{2}{*}{$\begin{array}{c}\text { Share of } \\
\text { total subsidy }\end{array}$} \\
\hline & & & With tariff & No tariff & With tariff & No tariff & & & & \\
\hline National & 0.73 & 102 & 88 & 134 & 0.03 & 0.04 & 39 & $1,190,384$ & $6,485,975$ & $100 \%$ \\
\hline Urban & 0.95 & 135 & 119 & 183 & 0.03 & 0.04 & 57 & 652,726 & $5,280,061$ & $81 \%$ \\
\hline Rural & 0.57 & 60 & 50 & 71 & 0.02 & 0.03 & 17 & 537,657 & $1,205,914$ & $19 \%$ \\
\hline \multicolumn{11}{|l|}{ Region } \\
\hline Metropolitan & 0.97 & 168 & 156 & 257 & 0.03 & 0.05 & 91 & 340,619 & $4,555,958$ & $70 \%$ \\
\hline North & 0.32 & 80 & 61 & 81 & 0.03 & 0.04 & 13 & 38,831 & 68,183 & $1 \%$ \\
\hline Northeast & 0.59 & 96 & 74 & 95 & 0.03 & 0.03 & 15 & 86,141 & 180,050 & $3 \%$ \\
\hline Southeast & 0.68 & 71 & 54 & 72 & 0.03 & 0.03 & 12 & 100,019 & 162,700 & $3 \%$ \\
\hline Central & 0.84 & 88 & 73 & 112 & 0.03 & 0.05 & 35 & 153,292 & 732,674 & $11 \%$ \\
\hline Southwest & 0.77 & 67 & 54 & 71 & 0.02 & 0.03 & 13 & 334,862 & 599,038 & $9 \%$ \\
\hline Northwest & 0.56 & 46 & 39 & 51 & 0.02 & 0.03 & 9 & 117,064 & 142,250 & $2 \%$ \\
\hline Peten & 0.36 & 115 & 92 & 112 & 0.03 & 0.04 & 17 & 19,556 & 45,122 & $1 \%$ \\
\hline \multicolumn{11}{|l|}{ Poverty } \\
\hline Non-poor & 0.89 & 128 & 112 & 171 & 0.03 & 0.04 & 52 & 794,359 & $5,807,678$ & $90 \%$ \\
\hline All poor & 0.54 & 48 & 39 & 56 & 0.03 & 0.04 & 13 & 396,024 & 678,298 & $10 \%$ \\
\hline Extreme poor & 0.31 & 47 & 39 & 52 & 0.04 & 0.05 & 7 & 189 & 181 & $0 \%$ \\
\hline \multicolumn{11}{|l|}{ Quintile } \\
\hline 1 (poorest) & 0.39 & 42 & 35 & 48 & 0.03 & 0.04 & 8 & 127,889 & 142,763 & $2 \%$ \\
\hline 2 & 0.63 & 48 & 40 & 56 & 0.02 & 0.03 & 13 & 205,107 & 373,094 & $6 \%$ \\
\hline 3 & 0.77 & 63 & 51 & 76 & 0.03 & 0.04 & 21 & 242,727 & 698,583 & $11 \%$ \\
\hline 4 & 0.9 & 100 & 79 & 127 & 0.03 & 0.04 & 44 & 295,368 & $1,747,755$ & $27 \%$ \\
\hline 5 (richest) & 0.95 & 184 & 171 & 255 & 0.03 & 0.04 & 74 & 319,293 & $3,523,779$ & $54 \%$ \\
\hline \multicolumn{11}{|l|}{ Ethnicity } \\
\hline Non-indigenous & 0.81 & 123 & 107 & 164 & 0.03 & 0.04 & 50 & 791,990 & $5,534,813$ & $85 \%$ \\
\hline Indigenous & 0.61 & 59 & 49 & 70 & 0.03 & 0.03 & 18 & 398,394 & 951,163 & $15 \%$ \\
\hline Quiche & 0.8 & 66 & 52 & 72 & 0.03 & 0.03 & 15 & 112,427 & 229,753 & $4 \%$ \\
\hline Q'eqchi & 0.27 & 69 & 52 & 74 & 0.03 & 0.04 & 15 & 21,797 & 44,463 & $1 \%$ \\
\hline Kaqchiqel & 0.85 & 72 & 61 & 91 & 0.03 & 0.04 & 28 & 116,886 & 440,690 & $7 \%$ \\
\hline Mam & 0.5 & 34 & 31 & 40 & 0.02 & 0.03 & 8 & 73,524 & 76,684 & $1 \%$ \\
\hline Other ind & 0.49 & 52 & 42 & 62 & 0.02 & 0.03 & 16 & 73,759 & 159,574 & $2 \%$ \\
\hline
\end{tabular}

: From this column on (i.e. to the right), the analysis focuses only on households that have an electricity meter

Source: World Bank calculations using the ENCOVI 2000, Instituto Nacional de Estadística - Guatemala 
Table C8: Probability that an unserved household was connected

\begin{tabular}{|c|c|c|c|c|c|c|c|c|c|}
\hline & \multicolumn{3}{|c|}{ Electricity } & \multicolumn{3}{|c|}{ Piped water ${ }^{\S}$} & \multicolumn{3}{|c|}{ Sanitary services" } \\
\hline & 1993-1996 & $1997-2000$ & $\%$ change & 1993-1996 & $1997-2000$ & $\%$ change & 1993-1996 & $1997-2000$ & $\%$ change \\
\hline National & $.18^{* * *}$ & 0.36 & $89 \%$ & $.19^{* * * *}$ & 0.34 & $79 \%$ & $.31^{* * *}$ & 0.55 & $77 \%$ \\
\hline Urban & $.38^{* * *}$ & 0.7 & $84 \%$ & $.31^{* * *}$ & 0.53 & $71 \%$ & $.50^{* * *}$ & 0.82 & $64 \%$ \\
\hline Rural & $.13^{* * *}$ & 0.29 & $123 \%$ & $.14^{* * *}$ & 0.28 & $100 \%$ & $.22^{* * *}$ & 0.48 & $118 \%$ \\
\hline Region & & & & & & & & & \\
\hline Metropolitan & $0.45^{* * *}$ & 0.73 & $63 \%$ & $0.33^{* * *}$ & 0.46 & $41 \%$ & $0.60^{* * *}$ & 0.73 & $22 \%$ \\
\hline North & $0.03^{* * *}$ & 0.15 & $335 \%$ & $0.09^{* * *}$ & 0.23 & $149 \%$ & $0.28^{* * *}$ & 0.5 & $78 \%$ \\
\hline Northeast & $0.06^{* * *}$ & 0.2 & $247 \%$ & $0.07^{* * *}$ & 0.38 & $431 \%$ & $0.16^{* * *}$ & 0.47 & $198 \%$ \\
\hline Southeast & $0.13^{* * *}$ & 0.34 & $167 \%$ & $0.19^{* * *}$ & 0.38 & $103 \%$ & $0.18^{* * *}$ & 0.39 & $118 \%$ \\
\hline Central & $0.23^{* * *}$ & 0.54 & $132 \%$ & $0.15^{* * *}$ & 0.31 & $110 \%$ & $0.30^{* * *}$ & 0.63 & $107 \%$ \\
\hline Southwest & $0.20^{* * *}$ & 0.46 & $127 \%$ & $0.18^{* * *}$ & 0.33 & $79 \%$ & $0.29^{* * *}$ & 0.64 & $122 \%$ \\
\hline Northwest & $0.20^{* * *}$ & 0.3 & $50 \%$ & $0.24^{* * *}$ & 0.33 & $38 \%$ & $0.30^{* * *}$ & 0.49 & $64 \%$ \\
\hline Peten & $0.05^{* * *}$ & 0.15 & $186 \%$ & $0.08^{* * *}$ & 0.19 & $121 \%$ & $0.15^{* * *}$ & 0.41 & $166 \%$ \\
\hline Poverty & & & & & & & & & \\
\hline Non-poor & $.06^{* * *}$ & 0.17 & $183 \%$ & $.13^{* * *}$ & 0.26 & $100 \%$ & $.21^{* * *}$ & 0.37 & $76 \%$ \\
\hline All poor & $.13^{* * *}$ & 0.28 & $115 \%$ & $.15^{* * *}$ & 0.29 & $93 \%$ & $.25^{* * *}$ & 0.44 & $76 \%$ \\
\hline Extreme poor & $.29^{* * *}$ & 0.55 & $90 \%$ & $.24^{* * *}$ & 0.41 & $71 \%$ & $.38^{* * *}$ & 0.72 & $89 \%$ \\
\hline Quintile & & & & & & & & & \\
\hline 1 (poorest) & $0.08^{* * *}$ & 0.22 & $191 \%$ & $0.13^{* * *}$ & 0.27 & $104 \%$ & $0.22^{* * *}$ & 0.38 & $71 \%$ \\
\hline 2.00 & $0.20^{* * *}$ & 0.34 & $74 \%$ & $0.18^{* * *}$ & 0.34 & $87 \%$ & $0.26^{* * *}$ & 0.48 & $83 \%$ \\
\hline 3.00 & $0.21^{* * *}$ & 0.44 & $110 \%$ & $0.18^{* * *}$ & 0.29 & $61 \%$ & $0.33^{* * *}$ & 0.62 & $87 \%$ \\
\hline 4.00 & $0.33^{* * *}$ & 0.54 & $62 \%$ & $0.22^{* * *}$ & 0.39 & $76 \%$ & $0.41^{* * *}$ & 0.73 & $76 \%$ \\
\hline 5 (richest) & $0.28^{* * *}$ & 0.68 & $140 \%$ & $0.32^{* * *}$ & 0.61 & $93 \%$ & $0.38^{* * *}$ & 0.82 & $113 \%$ \\
\hline Ethnicity & & & & & & & & & \\
\hline Non-indigenous & $.21^{* * *}$ & 0.42 & $100 \%$ & $.19^{* * *}$ & 0.35 & $84 \%$ & $.31^{* * *}$ & 0.57 & $84 \%$ \\
\hline Indigenous & $.16^{* * *}$ & 0.3 & $88 \%$ & $.18^{* * *}$ & 0.32 & $78 \%$ & $.30^{* * *}$ & 0.52 & $73 \%$ \\
\hline Quiche & $0.22^{* * *}$ & 0.53 & $138 \%$ & $0.23^{* * *}$ & 0.41 & $77 \%$ & $0.30^{* * *}$ & 0.46 & $51 \%$ \\
\hline Q'eqchi & $0.02^{* * *}$ & 0.09 & $368 \%$ & $0.07^{* * *}$ & 0.19 & $181 \%$ & $0.20^{* * *}$ & 0.58 & $199 \%$ \\
\hline Kaqchiqel & $0.23^{* * *}$ & 0.56 & $144 \%$ & $0.16^{* * *}$ & 0.32 & $100 \%$ & $0.41^{* * *}$ & 0.64 & $53 \%$ \\
\hline Mam & $0.17^{* * *}$ & 0.25 & $51 \%$ & $0.26^{* * *}$ & 0.39 & $49 \%$ & $0.33^{* * *}$ & 0.59 & $81 \%$ \\
\hline Other ind & $0.16^{* * *}$ & 0.22 & $43 \%$ & $0.18^{* * *}$ & 0.33 & $79 \%$ & $0.24^{* * *}$ & 0.4 & $66 \%$ \\
\hline
\end{tabular}


Table C9: Number of new connections in a three year before and after the Peace Accord

\begin{tabular}{|c|c|c|c|c|c|c|c|c|c|}
\hline & \multicolumn{3}{|c|}{ Electricity } & \multicolumn{3}{|c|}{ Piped water ${ }^{5}$} & \multicolumn{3}{|c|}{ Sanitary services" } \\
\hline & 1993-1996 & $1997-2000$ & $\%$ change & 1993-1996 & $1997-2000$ & $\%$ change & 1993-1996 & $1997-2000$ & $\%$ change \\
\hline National & $208,518.00$ & $329,734 * * *$ & $58 \%$ & $240,069.00$ & $352,336^{* * *}$ & $47 \%$ & $281,106.00$ & $350,418 * *$ & $25 \%$ \\
\hline Urban & $92,823.00$ & 105009 & $13 \%$ & $109,453.00$ & $128,593.00$ & $17 \%$ & $134,692.00$ & $109,792.00$ & $-18 \%$ \\
\hline Rural & $115,695.00$ & $224,725^{* * *}$ & $94 \%$ & $130,616.00$ & $223,743 * * *$ & $71 \%$ & $146,414.00$ & $240,626 * * *$ & $64 \%$ \\
\hline Region & & & & & & & & & \\
\hline Metropolitan & $54,521.00$ & 49430 & $-9 \%$ & $68,785.00$ & $65,250 * *$ & $-5 \%$ & $86,176.00$ & $41,926^{*}$ & $-51 \%$ \\
\hline North & $4,518.00$ & $18,977 * * *$ & $320 \%$ & $11,244.00$ & $25,361 * *$ & $126 \%$ & $11,043.00$ & $14,194.00$ & $29 \%$ \\
\hline Northeast & $6,007.00$ & $19,642 * *$ & $227 \%$ & $8,157.00$ & $40,250.00$ & $393 \%$ & $15,711.00$ & $39,447 * * *$ & $151 \%$ \\
\hline Southeast & $13,307.00$ & $39,944 * *$ & $200 \%$ & $24,129.00$ & $39,809 * * *$ & $65 \%$ & $19,052.00$ & $34,175^{* * *}$ & $79 \%$ \\
\hline Central & $25,794.00$ & $46,023 * * *$ & $78 \%$ & $19,129.00$ & $34,249.00$ & $79 \%$ & $24,577.00$ & $35,354^{*}$ & $44 \%$ \\
\hline Southwest & $61,419.00$ & $111,103^{* * *}$ & $81 \%$ & $65,222.00$ & $95,398 * *$ & $46 \%$ & $76,948.00$ & $121,819^{* * *}$ & $58 \%$ \\
\hline Northwest & $37,470.00$ & 45246 & $21 \%$ & $38,528.00$ & $40,355.00$ & $5 \%$ & $40,353.00$ & $46,521.00$ & $15 \%$ \\
\hline Peten & $2,726.00$ & $7,390^{* *}$ & $171 \%$ & $4,317.00$ & $8,737^{* *}$ & $102 \%$ & $6,199.00$ & $13,960 * * *$ & $125 \%$ \\
\hline Poverty & & & & & & & & & \\
\hline Non-poor & $13,662.00$ & $33,135 * * *$ & $143 \%$ & $24,253.00$ & $43,091 * *$ & $78 \%$ & $27,979.00$ & $38,674 *$ & $38 \%$ \\
\hline All poor & $95,296.00$ & $180,842 * * *$ & $90 \%$ & $108,754.00$ & $184,682 * * *$ & $70 \%$ & $132,815.00$ & $176,028^{* *}$ & $33 \%$ \\
\hline Extreme poor & $113,222.00$ & $148,892 *$ & $32 \%$ & $131,315.00$ & $167,654^{*}$ & $28 \%$ & $148,255.00$ & $174,390.00$ & $18 \%$ \\
\hline Quintile & & & & & & & & & \\
\hline 1 (poorest) & $27,646.00$ & $74,446^{* * *}$ & $169 \%$ & $45,018.00$ & $79,644 * * *$ & $77 \%$ & $53,797.00$ & $71,506^{* *}$ & $33 \%$ \\
\hline 2 & $56,845.00$ & $79,690^{*}$ & $40 \%$ & $54,036.00$ & $82,664 * *$ & $53 \%$ & $56,963.00$ & $76,914 *$ & $35 \%$ \\
\hline 3 & $47,313.00$ & $78,562 * * *$ & $66 \%$ & $50,301.00$ & $66,279 *$ & $32 \%$ & $67,856.00$ & $85,001.00$ & $25 \%$ \\
\hline 4 & $48,566.00$ & 52267 & $8 \%$ & $49,883.00$ & $67,898^{*}$ & $36 \%$ & $67,271.00$ & $69,273.00$ & $3 \%$ \\
\hline 5 (richest) & $25,391.00$ & 43840 & $73 \%$ & $20,273.00$ & $52,924.00$ & $161 \%$ & $34,173.00$ & $44,704.00$ & $31 \%$ \\
\hline Ethnicity & & & & & & & & & \\
\hline Non-indigenous & $117,976.00$ & $186,392 * * *$ & $58 \%$ & $133,965.00$ & $195,611 * * *$ & $46 \%$ & $166,007.00$ & $209,926^{*}$ & $26 \%$ \\
\hline Indigenous & $87,785.00$ & $142,414 * * *$ & $62 \%$ & $105,547.00$ & $153,789^{* * *}$ & $46 \%$ & $114,052.00$ & $137,572.00$ & $21 \%$ \\
\hline Quiche & $24,287.00$ & $44,912 * *$ & $85 \%$ & $25,581.00$ & $34,880.00$ & $36 \%$ & $26,347.00$ & $27,645.00$ & $5 \%$ \\
\hline Q'eqchi & $1,945.00$ & $8,928 * * *$ & $359 \%$ & $7,760.00$ & $20,327.00$ & $162 \%$ & $8,734.00$ & $21,000 *$ & $140 \%$ \\
\hline Kaqchiqel & $19,417.00$ & $36,647 * *$ & $89 \%$ & $18,406.00$ & $30,914 * *$ & $68 \%$ & $26,123.00$ & $23,484.00$ & $-10 \%$ \\
\hline Mam & $20,817.00$ & 26214 & $26 \%$ & $30,730.00$ & $33,853.00$ & $10 \%$ & $30,249.00$ & $36,923.00$ & $22 \%$ \\
\hline Other ind & $21,319.00$ & 25713 & $21 \%$ & $23,070.00$ & $33,824.00$ & $47 \%$ & $22,599.00$ & $28,519.00$ & $26 \%$ \\
\hline
\end{tabular}

Source: World Bank calculations using the ENCOVI 2000, Instituto Nacional de Estadística - Guatemala 


\section{Annex D: Understanding whether coverage deficits are due to demand or supply side factors}

Coverage is the traditional indicator of access to services. However, the drawback of this indicator is that it doesn't allow you to distinguish whether people don't use the service (a) because it is not available in their community, or (b) because they choose not to use it even if it is available. These two alternative supply-side and demand-side explanations have very different policy implications and hence it is useful to be able to distinguish between them.

\section{As a first step it is helpful to calculate coverage, availability and take-up indicators as follows.}

Coverage rate $=$ No. of households using the service/Total no. of households

Availability rate $=$ No. of households living in communities where the service is available/Total no.of households

Take-up rate $=$ No. of households using the service/No. of households living in communities where the service is available

\section{It is easy to show that:}

\section{Coverage rate $=$ Take-up rate * Availability rate}

\section{Using these indicators, it is straightforward to decompose the coverage gap between demand-side and supply-side factors.}

Unserved population $=100$ - Coverage rate

Pure demand side gap $=$ Availability rate - Coverage rate

Supply side gap $=$ Unserved population - Pure demand side gap

Pure supply side gap = supply side gap * take-up rate

Mixed demand and supply side gap = supply side gap* (100-take-up rate)

These indicators can be normalized in the following way to show the actual proportion of any service deficit that is attributable to supply side factors, demand-side factors or both.

Proportion of deficit attributable to demand side factors only = Pure demand side gap / Unserved population

Proportion of deficit attributable to supply side factors only = Pure supply side gap / Unserved population

Proportion of deficit attributable to both demand and supply side factors only = Mixed demand and supply side gap / Unserved population

\section{An example, may help to illustrate the methodology.}

\section{Availability rate $=80 \%$}

Take-up rate $=50 \%$

Coverage rate $=80 \% * 50 \%=40 \%$ 
Unserved population $=100 \%-40 \%=60 \%$

Pure demand-side gap $=80 \%-40 \%=40 \%$

Supply side gap $=60 \%-40 \%=20 \%$

Pure supply-side gap $=20 \% * 50 \%=10 \%$

Mixed demand and supply-side gap $=20 \% *(100 \%-50 \%)=10 \%$

Proportion of deficit attributable to demand side factors only $=40 \% / 60 \%=66 \%$

Proportion of deficit attributable to supply side factors only $==10 \% / 60 \%=17 \%$

Proportion of deficit attributable to both demand and supply side factors only $=10 \% / 60 \%=17 \%$ 